\title{
THE IMPACT OF PRIVATE SECURITIES LAWSUITS ON ACCOUNTING CONSERVATISM AND THE MODERATING INFLUENCE OF CORPORATE GOVERNANCE
}

by

Ryan Kerr

\begin{abstract}
A thesis
submitted to the Victoria University of Wellington

in fulfilment of the requirements of the degree of

Doctor of Philosophy
\end{abstract}

Victoria University of Wellington 


\section{STATEMENT OF ORIGINAL AUTHORSHIP}

I hereby confirm that the work presented in this thesis is my own original work that has been carried out through the School of Accounting and Commercial Law, Victoria University of Wellington, during my candidature as a $\mathrm{PhD}$ student. I declare that the material of this thesis has not been submitted either in whole or in part for the award of any other degree or diploma at this or any other university. To the best of my knowledge and belief, it contains no material previously published or written by other persons or institutions except where due reference has been made.

Ryan Kerr 


\section{ACKNOWLEDGEMENTS}

I wish to express my thanks to my co supervisors, Professor Tony Van

Zijl and Dr. Thu Phuong Truong for their guidance, insights and comments during the development of this thesis.

Additionally I would like to express my gratitude to the Victoria University of Wellington (VUW) professional staff who have supported me to complete this thesis. 


\begin{abstract}
This study investigates the impact of conduct which goes on to give rise to a securities lawsuit, and the filing of a securities lawsuit, on the level of accounting conservatism in financial reporting. This study also investigates the moderating influence of corporate governance on the level of accounting conservatism following conduct which goes on to give rise to a securities lawsuit, and the filing of a securities lawsuit. The study uses a sample of 617 privately enforced disclosure-related securities lawsuits against listed US firms, taken under SEC rule 10b-5 of the 1934 Securities Exchange Act, over the period 2002 to 2010. The results of the study indicate that following both the conduct that gives rise to a securities lawsuit, and the filing of a securities lawsuit, firms adopt higher levels of accounting conservatism. However, the study finds no evidence that corporate governance moderates the impact of securities lawsuits on the level of accounting conservatism.
\end{abstract}




\section{TABLE OF CONTENTS}

STATEMENT OF ORIGINAL AUTHORSHIP......................................i

ACKNOWLEDGEMENTS ................................................................ii

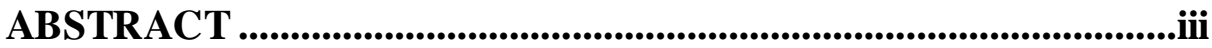

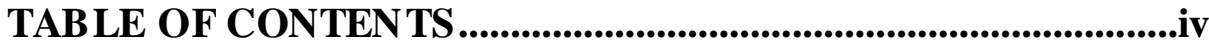

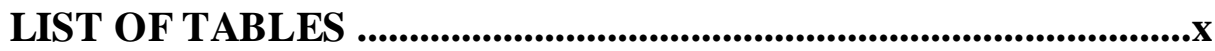

LIST OF FIGURES ..................................................................................

GLOSSARY AND ABBREVIATIONS............................................xiii

CHAPTER ONE: INTRODUCTION ...............................................1

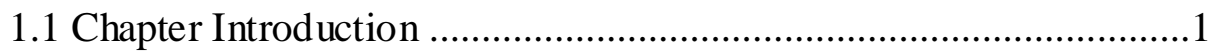

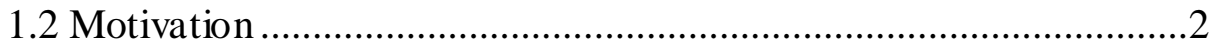

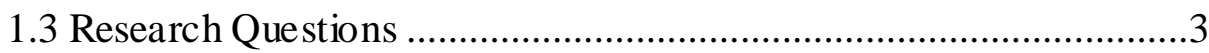

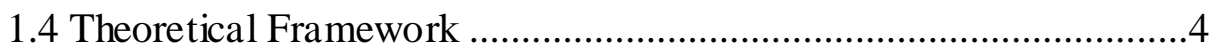

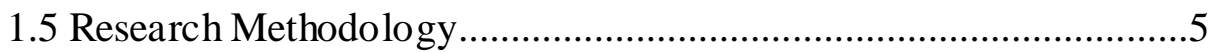

1.6 Summary of Key Findings ...........................................................

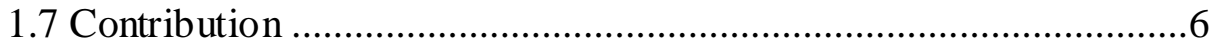

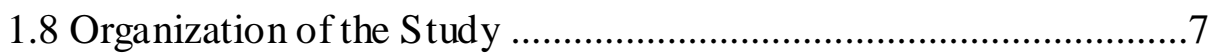




\section{CHAPTER TWO: OVERVIEW OF THE US INSTITUTIONAL

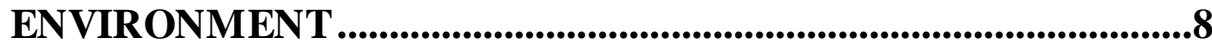

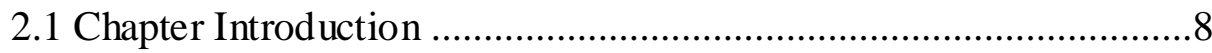

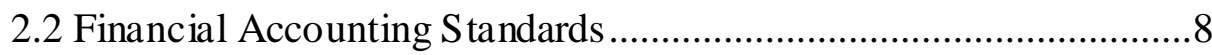

2.2.1 Accounting Standards and Conservatism Before 2010............10

2.2.2 Accounting Standards and Conservatism After 2010..............10

2.3 Private Securities Lawsuits and Disclosure Quality …....................11

2.4 Procedural Requirements of a Securities Lawsuit..........................11

2.4.1 Making a Material Misrepresentation or Omission .................12

2.4.2 The Required State of Mind (Intention or Recklessness).........13

2.4.3 Sale of a Security on the Market..................................................13

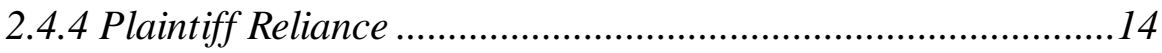

2.4.5 Plaintiff Suffered an Economic Loss as a Result ......................16

2.5 Securities Lawsuit Frequency and Trends ....................................17

2.6 Securities Lawsuit Losses ............................................................20

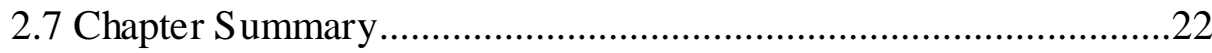

CHAPTER THREE: LITERATURE REVIEW, THEORETICAL

FRAMEWORK, AND HYPOTHESES ...............................................23

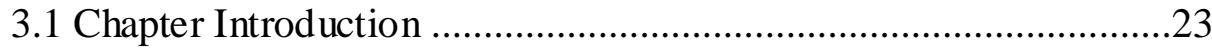

3.2 US Private Securities Lawsuits ......................................................24

3.2.1 Policy Merits of a Private Securities Lawsuit Regime ............24 
3.2.2 Securities Lawsuits Characteristics and Risk

3.2.3 Securities Lawsuit Settlement and Damages...........................29

3.3 Agency Theory and Contracting ....................................................33

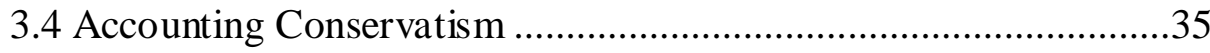

3.4.1 Types of Accounting Conservatism .............................................35

3.4.2 Primary Theory of Accounting Conservatism ..........................36

3.4.3 Alternative Theories of Accounting Conservatism...................37

3.4.4 Measures of Accounting Conservatism .....................................38

3.4.5 Accounting Conservatism and Lawsuit Risk ...........................45

3.5 Firm Disclosure and Securities Lawsuit Risk ...............................46

3.5.1 Firm Announcements and Securities Lawsuits.......................47

3.5.2 Financial Reporting and Securities Lawsuit Risk ....................50

3.6 Lawsuit Risk Evaluation following a Securities lawsuit..................51

3.7 Governance Change Following a Securities Lawsuit ......................52

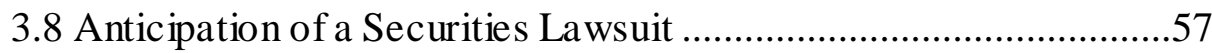

3.9 Statement of Hypothesis One and Hypothesis Two .........................57

3.10 Corporate Governance and Accounting Conservatism ..................58

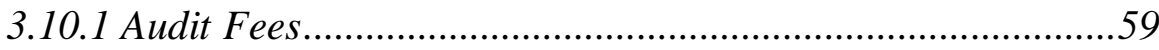

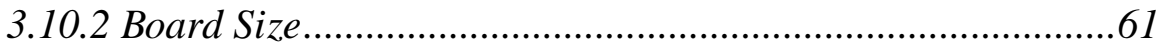

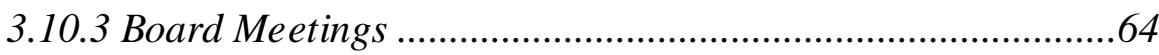

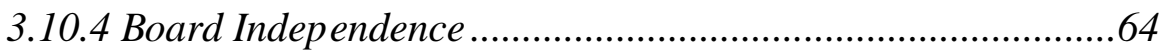

3.11 Statement of Hypothesis Three and Four .....................................67 
3.12 Chapter Summary

\section{CHAPTER FOUR: SAMPLE AND RESEARCH}

METHODOLOGY

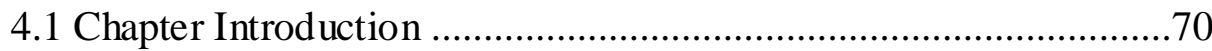

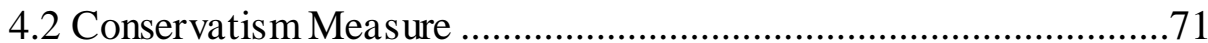

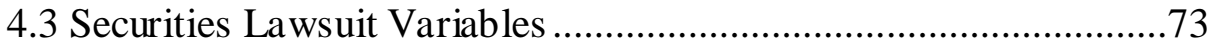

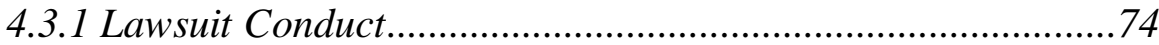

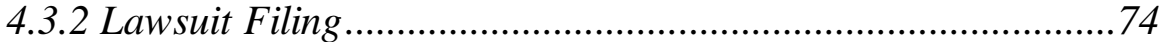

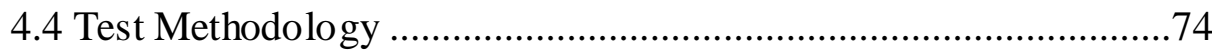

4.4.1 Test of Hypotheses One and Two ..........................................74

4.4.2 Model One Coefficient Sign Predictions ..................................75

4.4.3 Test of Hypotheses Three and Four.......................................77

4.4.4 Model Three Coefficient Sign Predictions ...............................78

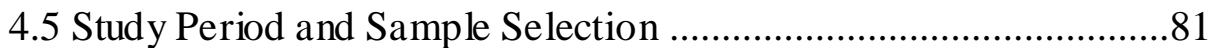

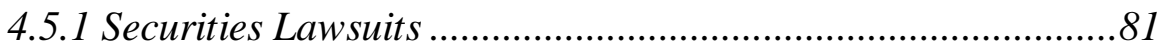

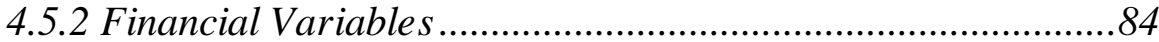

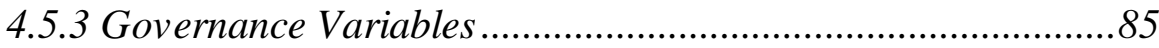

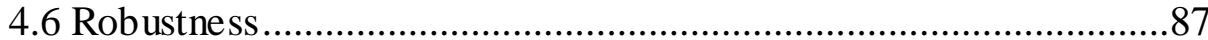

4.6.1 Prior Year Accounting Conservatism......................................87

4.6.2 Alternative Measures of Securities Lawsuits..........................8.87

4.6.3 Alternative Measure of Conservatism .....................................90

4.6.4 Self Selection Bias .............................................................. 


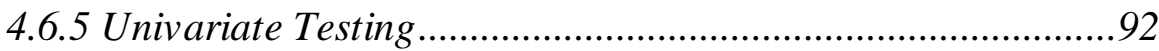

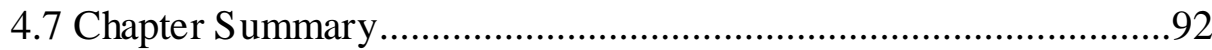

CHAPTER FIVE: RESULTS AND INTERPRETATION ..............94

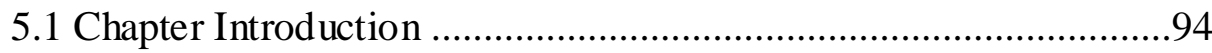

5.2 Descriptive Statistics ...................................................................94

5.3 Firm-Year Conservatism Measurement ..........................................96

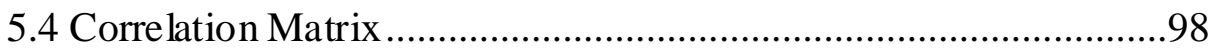

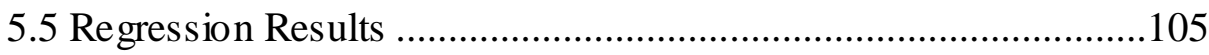

5.5.1 Securities Lawsuits and Conservatism (H1 and H2)............105

5.5.2 The Impact of Governance (H3 and H4) ..............................109

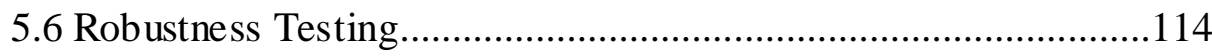

5.6.1 Lagged Conservatism (H1 and H2)....................................114

5.6.2 Alternative Lawsuit Measure (H1, H2, H3, and H4) ............117

5.6.3 Alternative Conservatism Measure (H1 and H2) ..................127

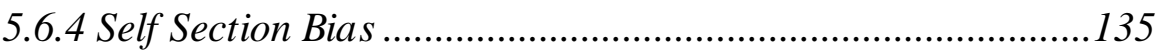

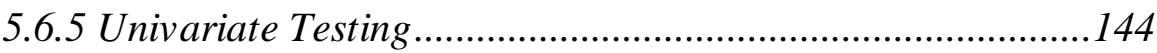

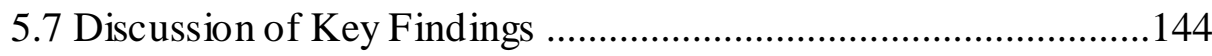

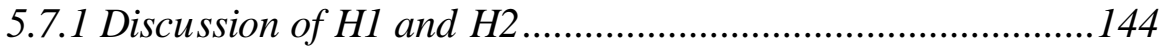

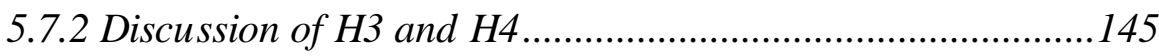

5.7.3 Discussion of Other Important Findings ...............................146

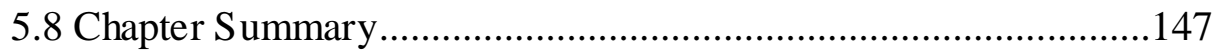

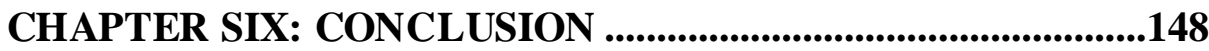


6.1 Chapter Introduction 148

6.2 Study Summary and Discussion of the Study .148

6.3 Contribution 151

6.4 Limitations and direction for future research 151

REFERENCES 154 APPENDIX ONE: VARIABLE DEFINITIONS 168 APPENDIX TWO: MEAN CSCORE BY FINANCIAL YEAR 171 APPENDIX THREE: A SELECTION OF CASE SUMMARIES 172 


\section{LIST OF TABLES}

Table 3-1: Characteristics of Securities Lawsuits ................................28

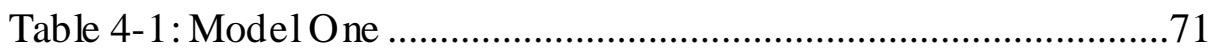

Table 4-2: Model One Variable Definitions ..........................................72

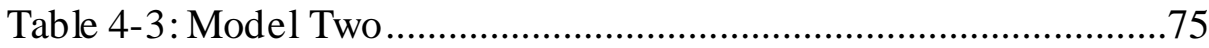

Table 4-4: Model Two Variable Definitions.........................................75

Table 4-5: Model Two Coefficient Sign Predictions ..............................77

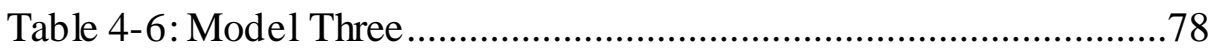

Table 4-7: Model Three Variable Definitions .........................................78

Table 4-8: Model Three Coefficient Sign Predictions ............................80

Table 4-9: Lawsuit Sample Selection....................................................82

Table 4-10: Lawsuits by Financial Year ................................................83

Table 4-11: Constructed Lawsuit Observations .....................................84

Table 4-12: Financial Sample Selection................................................ 86

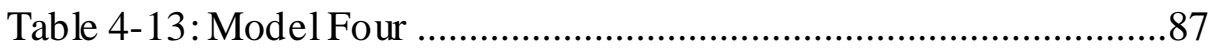

Table 4-14: Model Four Variable Definitions .......................................87

Table 4-15: Constructed Lawsuit Observations .....................................89

Table 4-16: Lawsuit Measurement Models and Definitions ..................89

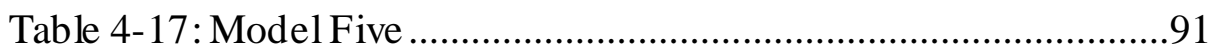

Table 4-18: Model Five Variable Definitions .......................................91

Table 5-1: Descriptive Statistics ……………….................................95

Table 5-2: Model 1 Mean Regression Coefficients ...............................97

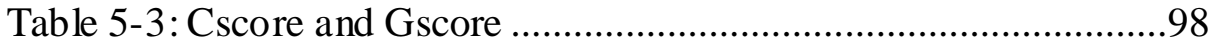

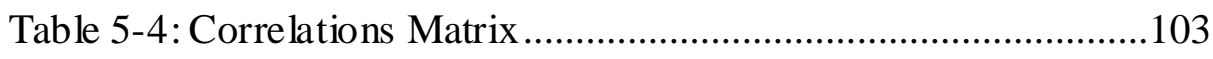

Table 5-5: Model 2a Regression Results.............................................107

Table 5-6: Model2b Regression Results ...........................................108

Table 5-7: Model 3a Regression Results.............................................111

Table 5-8: Model3b Regression Results ..............................................112 
Table 5-9: Variance Inflation Factor ..................................................113

Table 5-10: Model 4a Regression Results.............................................115

Table 5-11: Model 4b Regression Results ............................................116

Table 5-12: Model 2aa Regression Results.........................................120

Table 5-13: Model 2bb Regression Results .......................................121

Table 5-14: Model 3aa Regression Results..........................................122

Table 5-15: Model 3bb Regression Results ........................................123

Table 5-16: Variance Inflation Factor ..................................................124

Table 5-17: Model 4aa Regression Results..........................................125

Table 5-18: Model 4bb Regression Results .........................................126

Table 5-19: Model 5a Regression Results.............................................131

Table 5-20: Model 5b Regression Results ........................................132

Table 5-21: Model 5c Regression Results............................................133

Table 5-22: Model 5d Regression Results ...........................................134

Table 5-23: Model 2a Heckman Results .............................................136

Table 5-24: Model 2b Heckman Results............................................138

Table 5-25: Model 3a Heckman Results .............................................140

Table 5-26: Model 3b Heckman Results............................................142 


\section{LIST OF FIGURES}

Figure 2-1: Annual Number of Securities Lawsuits by Year.................19

Figure 2-2: Inflation Adjusted Disclosure Dollar Loss (Billions).........21

Figure 4-1: Lawsuit Conduct Period and Lawsuit Filing Date .............73 


\section{GLOSSARY AND ABBREVIATIONS}

FDA Food and Drug Administration

GAAP Generally Accepted Accounting Principles

IASB International Accounting Standards Board

IMR Inverse Mills Ratio

NASDAQ National Association of Securities Dealers

Automated

NYSE

New York Stock Exchange

PSLRA Private Securities Litigation Reform Act 1995

SCAC Stanford Securities Class Action Clearinghouse

SEA Securities and Exchange Act 1934

SEC Securities Exchange Commission

S\&P Standard \& Poor

UK United Kingdom

US United States of America

USD United States Dollar

USSC United States Supreme Court 


\section{CHAPTER ONE: INTRODUCTION}

\subsection{Chapter Introduction}

Financial reporting aims to ensure that information relevant to investors is conveyed clearly and in a timely fashion to the securities market. As such, the regulation of financial information plays a key role in ensuring capital markets function efficiently (Malkiel \& Fama, 1970). Where securities markets are more efficient, investor confidence is improved and securities market participants are able to access capital at a lower cost (Diamond and Verrecchia, 1991; Kim and Verrecchia, 1991; Leuz and Verrecchia, 2000).

An important regulatory feature of the US securities market is privately enforced securities lawsuits, taken under Securities Exchange Commission (SEC) rule 10b-5. The impact of these lawsuits on firm behavior has motivated a large number of studies (Rogers, Van Buskirk, and Zechman, 2011). In particular, studies that have investigated firm responses to securities lawsuits include investigation of the manipulation of accruals (Chalmers, Naiker, and Navissi, 2012) and changes in firm market disclosures (Rogers and Van Buskirk, 2009; Rogers et al. 2011). However, no studies have examined the impact of disclosure-related securities lawsuits on the level of accounting conservatism and the aim of this study is to fill this gap.

This study also examines the moderating influence of corporate governance. While there is extensive research examining the adoption of accounting conservatism and how firm governance can influence the 
level of accounting conservatism (Lara, Osma, and Penalva, 2009), there is no research that has examined how governance may moderate the relationship between private securities lawsuits and the level of accounting conservatism.

Section 1.2 sets out the motivation for this study. Section 1.3 presents the research questions. Section 1.4 describes the theoretical framework. Section 1.5 puts forward the research methodology. Section 1.6 presents a summary of this study's key findings. Section 1.7 summarizes the contribution of this study. Finally, section 1.8 notes the organization of the remainder of this study.

\subsection{Motivation}

Previous research has investigated how securities litigation risk (Khan and Watts, 2009; Liu, Thornton, and Elayan, 2013) and securities lawsuits taken under SEC rule 10b-5, influence firm decision making and disclosure choices (Chalmers et al. 2012; Ettredge, Huang, and Zhang, 2015; McTier and Wald, 2011). There is, however, limited research examining how lawsuits influence the level of conservatism in reporting practices. In particular, the research that has been completed in this area has focussed on specific disclosures, rather than financial reporting (Rogers and Van Buskirk, 2009). This study aims to bridge this gap in the literature and explore how accounting decision making, in particular on the level of accounting conservatism, may change as a result of a securities lawsuit, taken under SEC rule 10b-5.

A further motivation for this study is to examine the moderating influence of corporate governance. Governance has previously been 
examined as both a dependent variable and a control variable in studies examining the influence of private securities lawsuits (Lara et al. 2009; McTier and Wald, 2011). However, the research in this area has not considered the moderating influence of firm governance on accounting conservatism. This study aims to also fill this gap in the literature.

Finally, this study is motivated by the need to inform regulators of the influence of securities lawsuits on the level of accounting conservatism. This is to ensure that regulators and the legal system understand the influence of securities lawsuits on the quality of financial reporting.

\subsection{Research Questions}

This study examines the following questions;

1. Following the conduct that gave rise to a lawsuit, taken under SEC rule $10 \mathrm{~b}-5$, do firms adopt a higher level of conservatism?

2. Following a securities lawsuit, taken under SEC rule $10 \mathrm{~b}-5$, do firms adopt a higher level of conservatism?

3. Does corporate governance, as measured by (a) audit fees, (b) board size, (c) number of board meetings, and (d) the percentage of outside directors, moderate the relationship between the conduct that gave rise to a lawsuit, taken under SEC rule 10b-5, and firm adoption of a higher level of conservatism? 
4. Does corporate governance, as measured by (a) audit fees, (b) board size, (c) number of board meetings, and (d) the percentage of outside directors, moderate the relationship between securities lawsuits, taken under SEC rule 10b-5, and firm adoption of a higher level of conservatism?

\subsection{Theoretical Framework}

This study uses a contracting and agency framework to explain how private securities lawsuits, accounting conservatism, and firm governance are linked. Agency problems arise when information asymmetry facilitates management to pursue their own interests at the expense of the interests of firm investors (Jensen and Meckling, 1976). The literature on agency theory has identified a range of internal and external governance mechanisms designed to mitigate this divergence of interests between the firm and its investors.

Drawing on agency theory (Jensen and Meckling, 1976), this study views securities regulation as an external governance mechanism which reduces agency problems. In particular, securities lawsuits are theorized to achieve this reduction in information asymmetry by imposing direct and indirect costs on firms for withholding relevant information from investors. Thus lawsuits incentivize firms to engage in higher quality reporting. In particular, the adoption of accounting conservatism is viewed as a method for firms to achieve this higher quality reporting and thus reduce information asymmetry (Watts, 2003).

This study also considers internal governance arrangements as impacting on the degree of agency problems, with the level of information 
asymmetry determined by firm reporting decisions (Chen, Firth, Gao, and Rui, 2006; Lara et al. 2009).

\subsection{Research Methodology}

This study considers all private US disclosure-related securities lawsuits against publicly listed companies, over the period 1999 to 2012. The study period takes place after the Private Securities Litigation Reform Act (1995) (PSLRA) and therefore the sample is not subject to variation in the legislative framework. The final sample consists of 617 disclosurerelated securities lawsuits against firms listed on the New York Stock Exchange and the NASDAQ.

This study uses two different securities lawsuit events; the lawsuit filing date and the date of the alleged conduct. The study then constructs four different securities lawsuit variables to study these two lawsuit events over two different study periods. The study uses two different methods of measuring accounting conservatism, a firm-year measure of accounting conservatism (Khan and Watts, 2009) and an earnings measurement approach (Basu, 1997).

The study uses multivariate regression to investigate whether firms increase their level of accounting conservatism following conduct which gives rise to a securities lawsuit, and the filing of a securities lawsuit.

The regressions include governance interaction variables to investigate whether corporate governance moderates any increase in the use of accounting conservatism following on from the conduct which gives rise to a securities lawsuit, and the filing of a securities lawsuit event. 


\subsection{Summary of Key Findings}

The results suggest that US firms do increase the level of accounting conservatism in their financial reporting, following both conduct which gives rise to a securities lawsuit, and the filing of a securities lawsuit.

Overall the evidence does not support the proposition that corporate governance moderates the link between conduct which gives rise to a securities lawsuit, the filing of a securities lawsuit, and change in the level of accounting conservatism

\subsection{Contribution}

The findings of this study and the test methodologies employed contribute to the literature on the US private securities lawsuit regime and accounting conservatism. This study makes two key contributions that should be useful to academics, regulators, investors, standard setters, auditors and company directors.

The study uses a unique hand collected sample of disclosure-related securities lawsuits to draw specific conclusions on the impact of the private securities enforcement regime on accounting conservatism. The study's findings suggest that disclosure-related private securities lawsuit events initiate an increase in the level of accounting conservatism. This finding adds to the literature on the impact of private securities lawsuits and will be of interest to regulators in both the US and other jurisdictions. This finding will also be relevant to accounting standard setters and 
academics who are interested in the determinants of accounting conservatism.

This study also contributes to the literature on corporate governance and the level of accounting conservatism. In particular, the study finds evidence that board meetings moderate the link between the filing of disclosure-related securities lawsuits and accounting conservatism. This finding will be of interest to the users of financial reports and company directors and shareholders who establish and review board size.

\subsection{Organization of the Study}

The remainder of this study is organized as follows. Chapter two discusses the US commercial environment. In particular, this includes a review of the regulations surrounding financial reporting and private securities lawsuits in the US. Chapter three provides a literature survey on accounting conservatism, firm governance and securities lawsuits. Chapter three also develops the theoretical framework and the hypotheses for the study. Chapter four discusses the sample selection and the test methodology. Chapter five presents and interprets the results of the tests carried out. Chapter six summarises the findings of the study, states the conclusions, notes the contribution and limitations of the study and suggests possible areas for future research. 


\section{CHAPTER TWO: OVERVIEW OF THE US INSTITUTIONAL ENVIRONMENT}

\subsection{Chapter Introduction}

This chapter describes the US regulatory environment during the period 1999 to 2012. In particular, the chapter reviews the US accounting standards framework and the US private securities lawsuit regime.

Section 2.2 discusses the US Financial Accounting Standards Board (FASB), the accounting standards framework, and the place of accounting conservatism within the accounting standards framework. Section 2.3 reviews the legal framework surrounding US private securities lawsuits. Section 2.4 details the legal requirements for US private securities lawsuits, taken under SEC rule 10b-5. Section 2.5 provides an overview of the frequency and trends in US private securities lawsuits during the period 1999 to 2012. Section 2.6 examines firm losses arising from securities lawsuits. Section 2.7 provides a summary of the chapter.

\subsection{Financial Accounting Standards}

The Financial Accounting Standards Board (FASB) is a private, not-forprofit organization that establishes financial accounting and reporting standards for firms which follow generally accepted accounting principles (GAAP). The SEC has designated the FASB as the organization responsible for setting accounting standards for public companies in the US. 
The guidance issued by the FASB includes a statement of concepts which prescribes qualitative reporting characteristics. The statement of concepts provides a framework for accountants in applying accounting standards and for standard setters in developing standards.

In 1980 the FASB issued the Statement of Financial Concepts No. 2; Qualitative Characteristics of Accounting Information (1980). In 2010 the Statement of Financial Concepts No.2; Qualitative Characteristics of Accounting Information (1980) was superseded when the FASB issued the Statement of Concepts No. 8; Conceptual Framework for Financial Reporting (2010).

The Statement of Financial Concepts No. 2; Qualitative Characteristics of Accounting Information (1980) and the Statement of Concepts No. 8; Conceptual Framework for Financial Reporting (2010) both emphasize that the purpose of financial accounting is to provide accounting information for decision usefulness. The framework prescribes qualitative reporting characteristics that are designed to ensure accounting policy choice enhances the objective of decision usefulness. In the Statement of Concepts No. 8; Conceptual Framework for Financial Reporting (2010) the fundamental characteristics are stated to be relevance and representational faithfulness; together with comparability, verifiability, timeliness and understandability as enhancing characteristics.

Accounting practitioners are expected to make reporting decisions that are compliant with the fundamental and enhancing characteristics contained within the statement of concepts. As such, the fundamental 
requirements for relevance and representational faithfulness limit the ability of practitioners to legitimately choose extremely conservative or biased approaches to financial reporting.

\subsubsection{Accounting Standards and Conservatism Before 2010}

The Statement of Financial Concepts No. 2; Qualitative Characteristics of Accounting Information (1980) noted that firms operate in an uncertain economic environment and that the adoption of accounting prudence (accounting conservatism) is a legitimate financial reporting approach to deal with this uncertainty. The Statement of Financial Concepts No. 2; Qualitative Characteristics of Accounting Information (1980) defines acceptable accounting conservatism as accounting that does not undermine the reliability and integrity of information. Additionally, it notes that the consistent understatement of results may introduce a bias into financial reporting, which would conflict with the qualitative characteristics of financial reporting.

\subsubsection{Accounting Standards and Conservatism After 2010}

The Statement of Concepts No. 8; Conceptual Framework for Financial Reporting (2010) addresses the adoption of accounting conservatis $m$ differently from the earlier Statement of Financial Concepts No. 2; Qualitative Characteristics of Accounting Information (1980). Substance over form and accounting prudence (accounting conservatism), which were part of reliability in the earlier Statement of Financial Concepts No. 2; Qualitative Characteristics of Accounting Information (1980), are not considered part of faithful representation within The Statement of Concepts No. 8; Conceptual Framework for Financial Reporting (2010). 
The Statement of Concepts No. 8; Conceptual Framework for Financial Reporting (2010) notes that including accounting prudence (accounting conservatism) would be inconsistent with neutrality. In practice, the FASB recognition requirements continue to require the measurement of assets at the lower of cost or market and impairment testing which may lead to the use of accounting conservatism.

\subsection{Private Securities Lawsuits and Disclosure Quality}

Private securities lawsuits within the US are governed at the federal level by the Securities and Exchange Act (1934) (SEA) and regulated by the SEC. Using the authority granted to it under section $10 \mathrm{~b}$ of the SEA (1934), the SEC propagated rule 10b-5 which prohibits any act or omission resulting in fraud or deceit in connection with the purchase or sale of a security. The SEC Rule 10b-5 (b) introduces liability where

firms make any untrue statement of a material fact or omit to state a material fact, in connection with the sale of a security. Coffee (2006) noted, that a key purpose of this provision is to deter fraudulent earnings inflation within financial reporting. The SEC Rule 10b-5 (b) allows for both public and private enforcement.

\subsection{Procedural Requirements of a Securities Lawsuit}

The procedural requirements of US securities lawsuits arise from the SEC rule 10b-5 of the SEA (1943), the Private Securities Litigation Reform Act (1995) (PSLRA), and the case law surrounding the application of these statutes. The individual procedural requirements are addressed by Skinner (1994) who noted that the US Federal Courts require that for a securities lawsuit to succeed, both private and public 
plaintiffs must plead and prove five requirements. The first requirement is that the defendant made a material misrepresentation or omission. The second requirement is a strong inference that the defendant intended to make the material misrepresentation or omission, or acted with recklessness in making the misrepresentation or omission. The third requirement is that the defendant made a material misrepresentation or omission in connection with the purchase or sale of a security on the open market. The fourth requirement is that the plaintiff who was allegedly victimised by the fraud relied upon the material misrepresentation or omission. The fifth requirement is that the plaintiff suffered an economic loss as a result of the alleged fraud, with the plaintiff required to allege and prove loss causation.

The PSLRA (1995) added a series of new procedural barriers for securities lawsuits (Perino, 2003) and required plaintiffs to meet a higher pleading standard (Choi, 2004, Cummings, 2005 and Coffee, 2006). Specifically, the PSLRA (1995) introduced a requirement that plaintiffs must allege with particularity.

It is important to note that the securities lawsuits included in the sample for this study may not all meet of these criteria, with weak cases likely to have been brought against firms in the hopes of extracting immed iate value through pre-trial settlement. The procedural requirements of the SEC rule $10 \mathrm{~b}-5$ are examined in more detail below.

\subsubsection{Making a Material Misrepresentation or Omission}

The plaintiff must identify an allegedly fraudulent misrepresentation or omission within their pleadings (Skinner, 1994). 


\subsubsection{The Required State of Mind (Intention or Recklessness).}

The plaintiff must show a strong inference that the defendant acted with the required state of mind (intention or recklessness) (Skinner, 1994). In light of the requirements of the PSLRA (1995), in 2007 the law surrounding the required state of mind was clarified in Tellabs, Inc. v. Makor (2007). In Tellabs, Inc. v. Makor (2007), the District Court for the Northern District of Illino is found that the plaintiffs bought stock between $11^{\text {th }}$ of December 2011 and $19^{\text {th }}$ of June, 2012. The plaintiff alleged that during that time Tellabs purposely misled their investors. The District Court dismissed the case, holding that the plaintiffs did not make allegations with particularity, as required by the PSLRA (1995). The plaintiffs refiled and the District Court accepted that the plaintiff had sufficiently alleged that misleading statements were made, but found that the plaintiffs had not alleged that the defendant had acted with the required state of mind and again dismissed the lawsuit.

On appeal, the Seventh Circuit Court of Appeal reversed this dismissal, finding that the plaintiffs pleading had sufficiently alleged that the defendant acted with the requisite state of mind. On further appeal to the the United States Supreme Court (USSC), the court held that, the inference of the defendant's state of mind must be more than merely plausible or reasonable with the court holding that the inference of the defendants state of mind must be cogent and as compelling as any opposing inference (Tellabs v. Makor, 2007).

\subsubsection{Sale of a Security on the Market}


It is required that the plaintiff prove that the alleged material misrepresentation was connected with the purchase or sale of a security on the market (Skinner, 1994).

In SEC v. Texas Gulf Sulphur (1969) the United States Court of Appeals Second Circuit examined the required connection with the purchase or sale of a security. The New York District Court established that Texas Gulf Sulphur, a mining firm found and affirmed a mineral deposit. This finding was not released to the public. Following this discovery, the officers and directors of the firm engaged in share purchases. These purchases led to speculation of a mineral deposit having been discovered and were found to have influenced the share price of Texas Gulf Sulphur. The company made disclosures denying rumours of a mineral deposit while these share purchases were ongoing. Three days later, Texas Gulf Sulphur announced the mineral deposit discovery. The Second Circuit Court of Appeals held that SEC rule $10 b-5$ is breached when false assertions are made in a manner reasonably calculated to influence the investing public. The Court further found that, when a reasonable investor would be misled by the assertion and firm management is unable to demonstrate that it was diligent in publishing the whole truth or that the publication was made in good faith, then the assertion would be considered to be made in a manner calculated to mislead the investing public.

\subsubsection{Plaintiff Reliance}

It is required that the Plaintiff prove that they relied on a material misrepresentation or omission (Skinner, 1994). 
In the US Supreme Court case, Basic Inc. v. Levinson (1988), the court examined whether the statements made by Basic Incorporated met the standard for materiality. The case started as a lawsuit brought in the District Court for the Northern District of Ohio. The plaintiff alleged that there was fraud committed on all investors who sold stock in Basic Incorporated from the start of the first statement to the suspension of share trading. The plaintiff further alleged that all investors within the lawsuit class suffered from selling stock in Basic Incorporated at an artificially depreciated price.

The District Court established the facts of the case noting that Basic Incorporated had expressed an interest in a potential merger with Combustion Engineering Incorporated in 1965, and entered into a negotiation with Combustion Engineering Incorporated regarding a merger in 1976. During the next two years the firm made public statements to address an increased level of share trading, but in these statements they denied plans for a merger. On November 1978 a final statement denying the merger was issued. One month after this denial, on December $18^{\text {th }}$, trading in Basic Incorporated shares was suspended and Basic Incorporated acknowledged merger discussions.

The District Court granted a motion to dismiss the lawsuit under the Federal Rule of Civil Procedure 12(b) (6) (USSC, 1975). This rule provides that a lawsuit may be dismissed if the plaintiff's fails to plead an affirmative cause of action or sufficient facts under which relief can be granted (USSC, 1975). In particular, the District Court noted that the statements Basic Incorporated made regarding the merger were immaterial as they were not necessarily destined to become a merger agreement. 
The position of the District Court was overturned by the United States Court of Appeals for the Sixth Circuit, with the appellate court reversing the granting of the motion to dismiss. The appellate court found that a misstatement affects the entire market and, as a result, affects the price of securities. As such, the appellate court held that there is a presumption of reliance on the misstatement by an individual stock purchaser, even where the investor did not explicitly rely on a particular disclosure to make their investment. This position was affirmed by the USSC with commentators describing this presumption as the fraud on the market doctrine (Dyl, 1999; Francis, Philbrick, and Schipper, 1994).

\subsubsection{Plaintiff Suffered an Economic Loss as a Result}

The plaintiff is required to prove that they suffered an economic loss as a result of the material misrepresentation or omission (Skinner, 1994).

In the US Supreme Court case Dura Pharmaceuticals v. Broudo (2005), the plaintiffs alleged that Dura Pharmaceuticals Incorporated made misstatements about both drug profits and future Food and Drug Administration (FDA) approval of a new asthmatic spray device between 15 April 1997 and 24 February, 1998. The District Court for the Southern District of California established that on 24 February 1998, Dura Pharmaceuticals Incorporated had announced that its earnings would be lower than expected due to slower than expected drug sales. This statement resulted in Dura Pharmaceuticals Incorporated shares losing half of their value. 
The District Court held that the plaintiffs had failed to allege loss causation and had not proved that the defendant had the required state of mind when they made the misstatements. The US Court of Appeals for the Ninth Circuit reversed the District Courts finding on loss causation, finding that loss causation is established when the plaintiff can show that the share price on the date of purchase was inflated by the misrepresentation.

The US Supreme Court overturned the Ninth Circuit Court of Appeals decision, noting that there is not necessarily a logical link between an inflated purchase price and a later economic loss, as a number of additional factors may influence the inflated purchase price. The USSC held that for a securities lawsuit to succeed under SEC rule 10b-5 there must be causal connection between the loss and the alleged misrepresentation.

\subsection{Securities Lawsuit Frequency and Trends}

Ellen and Laura (2012) examined trends in securities lawsuits between 2002 and 2010 and found an average of 165 securities lawsuits per year. Figure 2-1 displays the annual number of total securities class action lawsuits by year (Ellen and Laura, 2012). A significant drop in securities lawsuits during the year 2006 can be noted in Figure 2-1, Cornerstone Research (2006) suggested three factors that influenced this reduction in securities lawsuits. Firstly, the high profile failures of Enron and WorldCom generated a high level of public interest in securities lawsuits and consequently there was more active securities enforcement activity by the SEC and the Department of Justice. Companies may have responded to these factors by engaging in less risky disclosure behavior. 
Secondly, in the 2006 year there was a lower than usual level of stock market volatility, which tends to result in a lower number of securities lawsuit filings. Thirdly, Cornerstone Research (2006) noted that the outstanding issues resulting from the boom bust equities period between the 1990s and early 2000s had passed.

Ellen and Laura (2012) link the start of a rise in the level of securities lawsuits during the 2007 year to the start of the subprime mortgage crisis. The subprime mortgage crisis was regarded as having affected the frequency of securities lawsuits directly, as investors sued firms for inaccurate disclosures regarding holdings and operations and also indirectly, with an increase in stock market price volatility (Ellen and Laura, 2012). Securities lawsuits linked to the subprime mortgage crisis are noted in Figure 2-1. 
Figure 2-1: Annual Number of Securities Lawsuits by Year

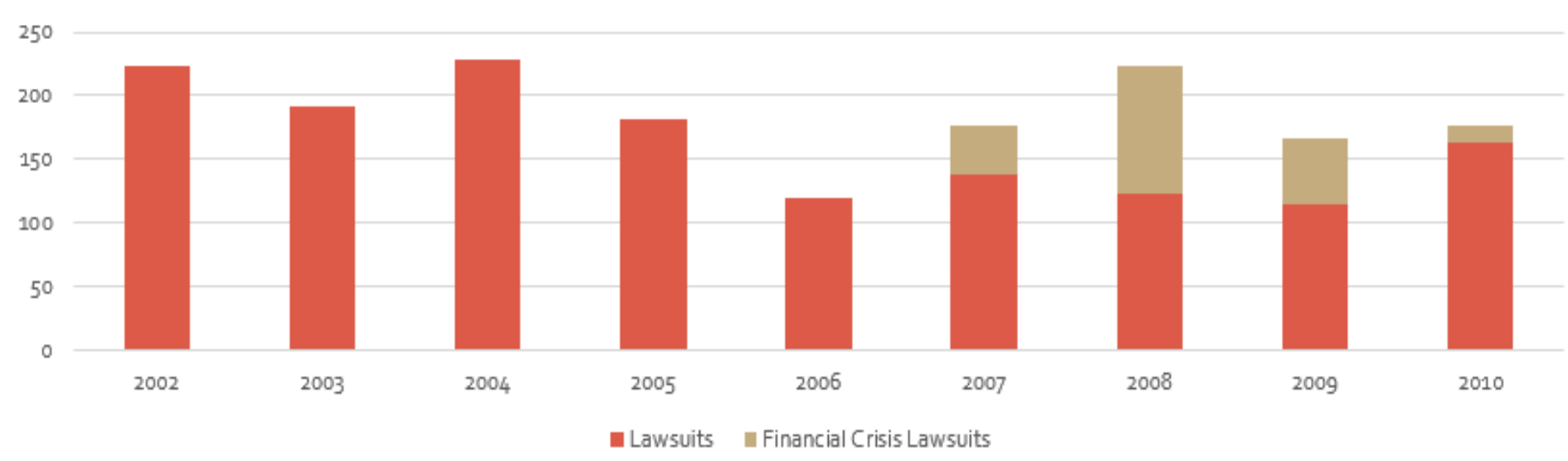

Data sourced from Ellen and Laura (2012). 
Reviewing these findings in more detail, Ellen and Laura (2012) reported that $23 \%$ of securities lawsuits in the second half of 2007 were related to subprime mortgage investments. Ellen and Laura (2012) also noted that the subprime mortgage crisis continued to affect the volume of securities lawsuits in 2008 and 2009, where 39\% of total securities lawsuits were mortgage crisis related.

\subsection{Securities Lawsuit Losses}

Ellen and Laura (2012) used the disclosure dollar method to estimate the losses for firms subject to a securities lawsuit. The disclosure dollar method measures the decrease in the market capitalization from the beginning to the end of the alleged misconduct period. Ellen and Laura (2012) found an inflation adjusted average yearly disclosure dollar loss of 123 billion dollars between the years 2002 to 2010. A significant drop in securities lawsuit losses in 2006 can be noted in Figure 2-2. Ellen and Laura (2012) suggested that this drop is due the reduced number of total securities lawsuits and reduced volatility in the market place. 
Figure 2-2: Inflation Adjusted Disclosure Dollar Loss (Billions)

250

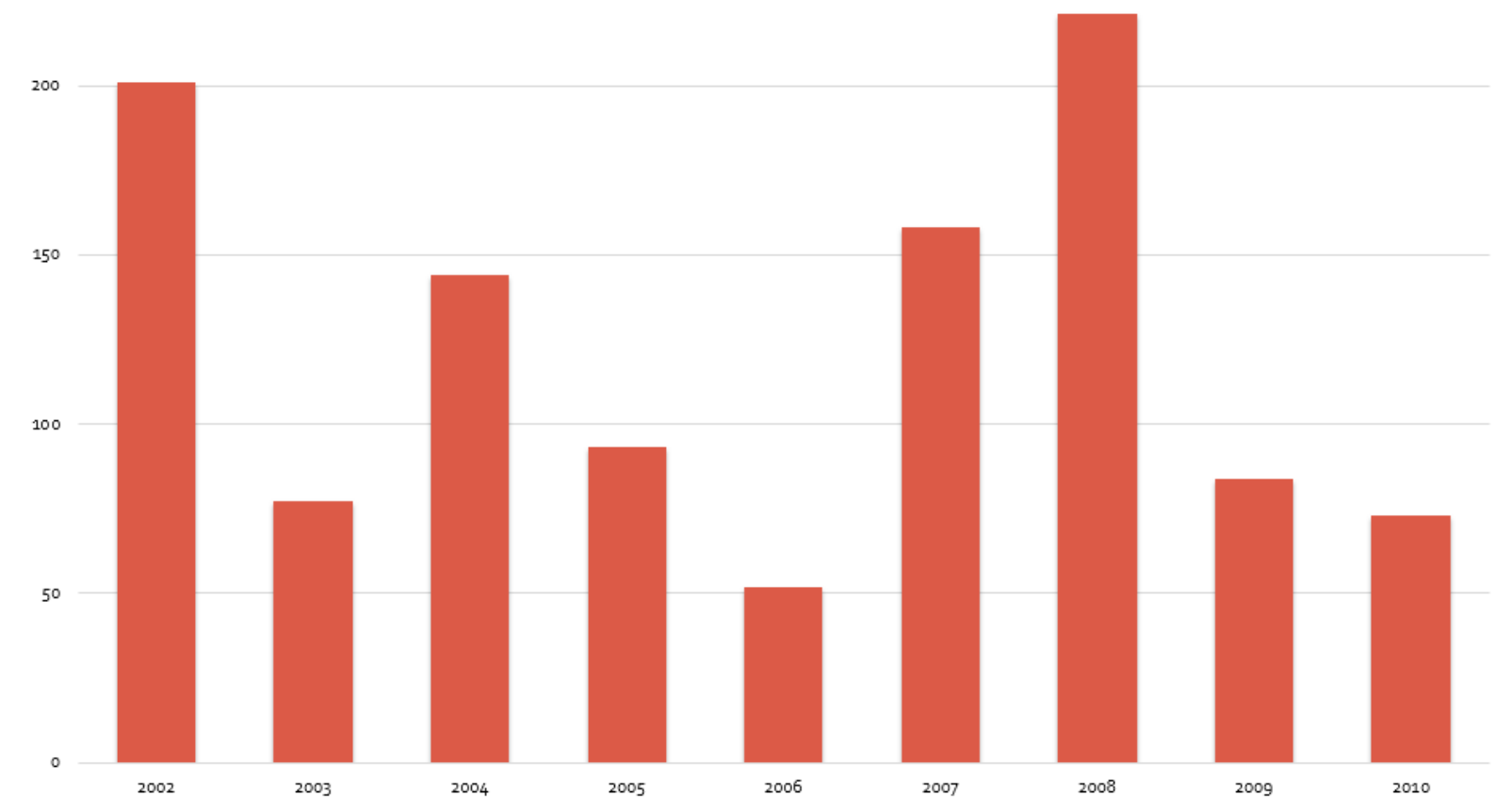

Data sourced from Ellen and Laura (2012). 


\subsection{Chapter Summary}

This chapter reviews key aspects of the commercial and legal environment that impact on firms' operations and reporting.

Financial reporting guidance from the FASB is examined, with this chapter reporting that the fundamental requirements for relevance and representational faithfulness limit the ability of practitioners to legitimately choose extremely conservative or biased approaches to financial reporting. This chapter goes on to consider that accounting practitioners are expected to make reporting decisions that are compliant with financial reporting fundamental and enhancing characteristics.

The US legal environment surrounding securities lawsuits is also discussed. In particular, the chapter examines the procedural requirements to succeed with a securities lawsuit taken under SEC rule $10 b-5$.

Finally, this chapter reviews the frequency of securities lawsuits within the US and the magnitude of securities lawsuit losses, indicating the economic damage suffered by firms subject to a securities lawsuit. Notably, this information indicates that securities lawsuits are common, linked to external macroeconomic events, and come at high cost to firms. 


\section{CHAPTER THREE: LITERATURE REVIEW, THEORETICAL FRAMEWORK, AND HYPOTHESES}

\subsection{Chapter Introduction}

Private securities lawsuits perform an important role in the efficient functioning of the securities market by reducing the information asymmetry between the firm and its investors. This improves the confidence of investors and ultimately lowers the cost of capital for firms (Malkiel and Fama, 1970). Likewise, accounting conservatism is viewed as a mechanism that reduces information asymmetry between firms and their investors (Watts, 2003). This chapter reviews the literature concerning securities lawsuits and the level of accounting conservatis m. This chapter also considers the literature on corporate governance as it relates to securities lawsuits and the level of accounting conservatism.

Section 3.2 provides a summary of the literature concerning the policy merits, outcomes, characteristics, and settlement of private securities lawsuits. Section 3.3 examines the problems of agency theory and provides a theoretical framework for this study. Section 3.4 reviews the literature on accounting conservatism. Section 3.5 examines firm disclosures and their association with securities lawsuit risk. Section 3.6 examines lawsuit risk evaluation following a securities lawsuit. Section 3.7 examines governance change following a securities lawsuit. Section 3.8 examines how firms respond when they anticipate a securities lawsuit. Section 3.9 sets out hypothesis one and hypothesis two. Section 3.10 examines the literature on corporate governance and how it interacts 
with the level of accounting conservatism. Section 3.11 sets out hypothesis three and hypothes is four. Section 3.12 provides a summary of the chapter.

\subsection{US Private Securities Lawsuits}

Private securities lawsuits taken under SEC rule 10b-5 have been described as the primary mechanism for investors to enforce US corporate disclosure requirements (Coffee, 2006; Jackson, 2007). The literature has investigated the policy merits and settlement of securities lawsuits.

\subsubsection{Policy Merits of a Private Securities Lawsuit Regime}

The literature has considered the public and private enforcement of securities lawsuits in the US. The literature shows that private enforcement forms the majority of securities lawsuits in the US.

The main reason given for this is the financial incentive that private shareholders have to file a securities lawsuit (Coffee 2006; Jackson 2007). The literature has considered the merits of the US private securities lawsuit regime, examining whether private enforcement is dependent on the defendant's actual behavior and has reached mixed conclusions.

Arlen and Carney (1992) examined the securities lawsuit regime and argued that securities lawsuits do not have the desired deterrent effect, as securities lawsuits target the firm rather than members of the firm's executive. Drawing on agency theory, Arlen and Carney (1992) noted 
that the executives may find that they are incentivised to engage in fraud on the market, knowing that there are limited personal consequences for doing so. Arlen and Carney (1992) argued for a new regulatory approach of agent liability and criminal penalties, in place of the US private securities lawsuit regime.

Seligman (1994) reviewed a sample of private securities lawsuits between 1989 and 1992 and found that private securities enforcement is an effective deterrent against fraudulent accounting disclosures. Seligman (1994) further found that there is no persuasive case to amend SEC rule 10b-5, which provides for securities lawsuits following a misstatement or omission.

Choi (2004) discussed the evidence on the desirability of securities class actions for jurisdictions, noting that the benefits of pursing a securities lawsuit as a single plaintiff are often outweighed by the costs of doing so. Choi (2004) noted that a securities class action regime can provide strong deterrence, with the caveat that US styled securities class action regimes may need to be tailored to a new context when adopted in other jurisdictions. Choi (2004) further noted that private class actions lawsuit regimes can result in frivolous lawsuits and lack incentives for lawyers to bring lawsuits against smaller firms.

Coffee (2006) reviewed securities lawsuits during 2002, 2003 and 2004 and, contrary to Seligman (1994), found that private enforcement of securities law acts as a pointless shifting of wealth between shareholders. Rose (2008) reviewed the securities enforcement role of the SEC and the private enforcement of securities lawsuits, finding on balance, that the securities lawsuit regime could be significantly improved. In particular, 
Rose (2008) noted that the regulation surrounding private securities lawsuits acts as a bounty hunter provision and can lead to undesirable excessive enforcement. Rose (2008) argued for the SEC to have a supervisory role over all private enforcement actions.

\subsubsection{Securities Lawsuits Characteristics and Risk}

Firm and industry characteristics are noted within the literature as affecting securities lawsuit risk. In particular, Alexander (1991), Jones and Weingram (1996), and Skinner (1994) examined market capitalization and stock return variables, including share turnover as a proxy for securities lawsuit risk, they found that lawsuit damages rise when a greater number of shares have been traded.

Beck and Bhagat (1997) investigated shareholder lawsuits against public firms in the US. Beck and Bhagat (1997) used a sample of 1016 firms which were subject to securities lawsuits during the period January 1990 through to December 1993 and a matching sample of firms not subject to securities lawsuits, which were matched by standard industrial classification and price performance. Beck and Bhagat (1997) categorized the securities lawsuits that were faced by the firms in their sample by defendant type, the type of security held by the plaintiff, the type of transaction alleged to have involved deficient reporting, and the alleged fraud type. Beck and Bhagat (1997) noted that securities lawsuits tended to make multiple allegations and that some securities lawsuits are coded into more than one category.

Beck and Bhagat (1997) found, consistent with Grundfest and Perino (1997), that defective forecasts and financial reports of sales and earnings 
represented a large proportion of securities lawsuits. Beck and Bhagat (1997) also noted that a higher percentage of securities lawsuits arise from alleged improper disclosure and forecasting, rather than alleged improper transactions. The breakdown of securities lawsuits by category is reported in Table 3-1 below. 
Table 3-1: Characteristics of Securities Lawsuits

\begin{tabular}{lc}
\hline Lawsuit Characteristics & $N$. \\
\hline Defendant type & 455 \\
\hline Officers/directors & 159 \\
Other firms & 118 \\
Underwriters & 94 \\
Auditors/ Accountants & 89 \\
Other Shareholders & 49 \\
Attorneys & 23 \\
Other & \\
\hline Security type held by Plaintiff & 416 \\
\hline Common Stock & 28 \\
Bonds & 2 \\
Options/Warrants & 1 \\
Preferred Stock & 53 \\
Other combination & \\
\hline
\end{tabular}

Transaction alleged to have involved deficient reporting

\begin{tabular}{ll}
\hline Routine reporting & 261
\end{tabular}

Merger/acquisition $\quad 92$

IPO 36

Seasoned Equity Issue $\quad 28$

Limited Partnership $\quad 22$

$\begin{array}{lr}\text { General restructuring } & 18\end{array}$

$\begin{array}{ll}\text { LBO } & 7\end{array}$

Initial Debt issue 4

Other $\quad 32$

\begin{tabular}{lc}
\hline Alleged fraud type & \\
\hline Defective forecast of sales/earnings & 401 \\
Defective report of current sales/earnings & 399 \\
Defective asset report & 357 \\
Market manipulation & 154 \\
Other/insider trading/fraud related fraud & 149 \\
Defective product report & 95 \\
Insider Trading & 28 \\
Embezzlement & 16 \\
\hline
\end{tabular}

Table sourced from Beck and Bhagat (1997). 
Beck and Bhagat (1997) found evidence that firms subject to a securities lawsuit are likely to experience price declines prior to the securities lawsuit.

Kim and Skinner (2012) used a sample of 2,497 securities lawsuits from the period 1996 to 2009 to examine lawsuit risk. Kim and Skinner (2012) found that, while industry provides some insight into lawsuit risk, there is a possibility that using industry as a proxy for lawsuit risk captures unrelated factors. The authors added that when industry is suppleme nted with firm characteristics including size, growth, stock performance, and volatility, the ability of a lawsuit risk proxy to accurately forecast lawsuits increases.

Gillan and Panasian (2014) used a sample of 350 Canadian companies listed on the Toronto Stock Exchange (TSX) during the years 1995, 2000, and 2005, to investigate whether director and officer insurance provides any insights into the likelihood of being sued. Gillan and Panasian (2014) found that firms with director and executive officer insurance coverage are more likely to be sued and that the likelihood of a lawsuit increases with higher coverage.

\subsubsection{Securities Lawsuit Settlement and Damages}

Langevoort (1996) reviewed the literature on US securities lawsuits, case law, and the PSLRA (1995). Langevoort (1996) noted that damages calculations can be grossly disproportionate to the nature of the alleged lawsuit conduct and expressed the view that this encourages securities lawsuits of low merit. Langevoort (1996) proposed capping the total damages on securities lawsuits, noting that damages are being funded 
directly by other investors, rather than the executives of the firm who engaged in the alleged lawsuit conduct.

Alexander (1996) reviewed the literature on US securities lawsuit settlements, case law and the PSLRA (1995). Alexander (1996) noted that damages are often not related to the holistic costs of the alleged lawsuit conduct and are difficult for courts to calculate. Alexander (1996) proposed that a schedule of civil penalties enforceable through litigation should instead be adopted, noting that a schedule of penalties would provide a greater deterrence value and a lower enforcement cost.

Cox (1997) reviewed the literature on US securities lawsuit settlements, case law and the PSLRA (1995). Cox (1997) argued that the lawsuit settlement process is not transparent and that the judiciary needs to be more active in reviewing the terms of securities lawsuit settlements before approving them.

Beck and Bhagat (1997) also tested whether securities lawsuit settlements are explainable using firm-specific information and suit characteristics, using a sample of 473 US firms which settled a securities lawsuit during the period 1990 to 1993. Beck and Bhagat (1997) found that settlement values were related to the seriousness of allegations contained in the securities lawsuit, the length of time shareholders allege they were misled, and an overly optimistic tone in the alleged misleading disclosures. Niehaus and Roth (1999) examined Securities Class Action Alert newsletters between the years 1988 to 1994 and found that $96.6 \%$ of securities lawsuits settled out of court with an average settlement of 7 million USD and a median settlement of 3.5 million USD. 
Martin, Juneja, Foster, and Dunbar (1999) used a sample of 1,349 US securities lawsuits from the period January 1991 to June 1998. Martin et al. (1999) found that $83 \%$ of sued firms reached a settlement and that on average securities lawsuit settlements were $14 \%$ of the plaintiffs claimed damages. Martin et al. (1999) also noted that $25 \%$ of securities lawsuits settled for less than two million USD. Martin et al. (1999) found that the merits of securities lawsuits seem to be of relatively little importance in determining total settlement amounts and that insurance limits were a better indicator.

Cox and Thomas (2006) used a sample of 129 US securities lawsuits from the period 1996 to 2004, in which the court appointed an institutional investor as the lead plaintiff. Cox and Thomas (2006) found that the court has a preference for institutional investors as lead plaintiffs. Cox and Thomas (2006) also found that securities lawsuits resulted in higher awarded damages when an institutional investor was the lead plaintiff.

Baker and Griffith (2008) examined the factors involved in the securities lawsuit settlement process and specifically whether the settlement of securities lawsuits is linked to the merits of those lawsuits. Baker and Griffith (2008) gathered qualitative data for the period 2006 to 2007 by interviewing 50 people who were either directors, executive officers, litigators or insurance claim managers. Baker and Griffith (2008) reported that securities lawsuit settlements are usually at or just above the director and executive officer insurance coverage, indicating that securities lawsuit settlements result in minimal changes to firm retained cash or dividends. Baker and Griffith (2008) further found that director and executive officer insurance influences the way plaintiffs draft their 
pleadings, with plaintiffs drafting their pleadings to avoid triggering any director and executive officer policy exclusions. The authors also noted that securities lawsuits are likely to result in increases in director and executive officer insurance premiums.

Eisenberg and Lanvers (2009) investigated securities lawsuit settlement rates across a range of civil actions. In particular, Eisenberg and Lanvers (2009) examined a sample of 3,300 securities lawsuits in two US federal districts; the Eastern District of Pennsylvania and the Northern District of Georgia. Eisenberg and Lanvers (2009) found that during the period 2001 to 2002, 66.9\% of cases settled. Eisenberg and Lanvers (2009) concluded that the evidence points to securities lawsuit settlements being determined by the merits of the lawsuit.

McShane, Watson, Baker, and Griffith (2012) used a hierarchical Bayesian model to build a predictive model of securities lawsuit outcomes and settlement amounts. McShane et al. (2012) used a sample of 1,198 securities lawsuits and a sample of 785 securities lawsuit settlements between the years 1996 to 2004. McShane et al. (2012) found a range of factors that indicate whether a securities lawsuit will be likely to succeed and the settlement amount. In particular, the authors found that a securities lawsuit is more likely to settle if there are more classes or types of securities associated with the case, a higher return on the S\&P 500 during the class period, a GAAP violation alleged, and if the lawsuit lists an individual plaintiff. The authors also found that a lawsuit is less likely to settle if it resulted from a longer filing time, there is a higher company return during the class period, it has an institutional plaintiff listed, and it has greater public notoriety. 
Amoah and Tang (2013) examined a sample of 185 US firms which issued an accounting restatement and were sued between 1997 and 2005. Amoah and Tang (2013) found that securities lawsuits concerning accounting irregularity-induced restatements were more likely to be settled out of court.

\subsection{Agency Theory and Contracting}

The literature on agency theory describes the purpose of firms as being to minimise transaction costs (Coase, 1937; Jensen and Meckling, 1976). Specifically, the literature notes that a firm allows for the minimization of searching for, monitoring, and enforcing contracts (Coase, 1937; Jensen and Meckling, 1976).

Jensen and Meckling (1976) theorized about agency problems and noted that while firms allow for the reduction of transaction costs they are subject to costs associated with the management of shareholder capital. Jensen and Meckling (1976) described agency costs in more detail, specifically as the costs associated with the delegation of decisionmaking authority from a principal (shareholder) to an agent (manager). Jensen and Meckling (1976) assumed that both the principal and the agent are wealth-maximizing and, as such, there is no reason to expect that managers will always act in the best interests of shareholders. Jensen and Meckling (1976) noted that agents (management) who make decisions on behalf of principals (investors), will have first-hand knowledge of firm activities and insight into current and future firm earnings potential. This insight into firms' activities and earnings potential is expected to create an asymmetry of information between principals and their agents. According to Jensen and Meckling (1976), 
the information asymmetry between principals and their agents is expected to lead to situations of moral hazard, where agents may not meet their contracted obligations, as well as adverse selection, where investors cannot verify the actual economic value of their firm or the value contributed by management (Akerlof, 1970).

Thus, Principals can partially address agency problems through the use of internal governance mechanisms, while regulators and standard setters can implement external governance mechanisms (Jensen and Meckling, 1976). External governance mechanisms, such as the US private securities enforcement regime and accounting framework were discussed in chapter two.

Managers are expected to recognise these external governance requirements to avoid securities lawsuit losses, reputational penalties, and criminal charges. Internal governance, notably resources of the board, use of quality auditors, and independence of the board, will also indicate the ability and willingness of the board to monitor management for agency problems (Ahmed and Duellman, 2007). In particular, more independent and better-resourced boards are expected to respond more diligently to investor demand for reductions in information asymmetry, possibly through the adoption of accounting conservatism (Lara et al. 2009).

Additionally, firms may seek to lower information asymmetry to signal reduced agency costs to investors. This signalling may lower the likelihood of lawsuit risk or improve the reputation of management (Skinner, 1997; Watts, 2003). 


\subsection{Accounting Conservatism}

Accounting conservatism has been described as being a practice that underpins accounting (Basu, 1997; Bliss, 1924; Mueller, 1964; Sterling, 1967). Basu (1997) observed that firms adopt conservative reporting practices independently of regulation and the legal environment.

\subsubsection{Types of Accounting Conservatism}

The literature identifies two kinds of accounting conservatism; balance sheet conservatism, which is news independent and described as unconditional conservatism, and income statement conservatism, which is news dependent and described as conditional conservatism (Ball, Kothari, and Robin, 2000; Basu, 1997; Basu, 1995; Beaver and Ryan, 2005; Easton and Pae, 2004).

Unconditional conservatism occurs when the book values of assets are understated and the book value of liabilities is overstated (Beaver and Ryan, 2005). Examples of unconditional conservatism include the expensing of goodwill and other internally generated intangibles at inception, depreciation on property plant and equipment at a rate faster than economic depreciation and the decision to evaluate the book value of positive net present value assets at historical cost (Beaver and Ryan, 2005). Conditional conservatism focuses on the recognition of revenue and expenses, with the book values of assets written down in adverse circumstances but not written up under favorable circumstances (Beaver and Ryan, 2005). Examples of conditional conservatism include measuring inventory at the lower of cost or market value and the decision to impair tangible and intangible assets (Beaver and Ryan, 2005). 
Beaver and Ryan (2005) investigated conditional and unconditional conservatism. Examining how unconditional conservatism and conditional conservatism interact. Beaver and Ryan (2005) found that an increased application of unconditional conservatism resulted in a decrease in the adoption of conditional conservatism. Beaver and Ryan (2005) added that firms were less likely to incorporate bad news asymmetry over good news into their earnings when they have a buffer from unconditional accounting conservatism. Beaver and Ryan (2005) further found that if the bad news is sufficiently bad to erode the buffer from unconditional conservatism, then firms will fall back on conditional conservatism. Beaver and Ryan (2005) additionally noted that conditional and unconditional accounting conservatism methodologies are adopted by firms to achieve similar objectives.

Beaver and Ryan (2005) discussed the differences in the application of conditional and unconditional conservatism noting that a disclosure strategy that uses conditional conservatism can be implemented quickly while a disclosure strategy using unconditional conservatism is slower to implement. Thus, it is expected that firms seeking to rapidly adopt conservative reporting, in response to an external event such as a securities lawsuit, will choose to use conditional conservatism.

\subsubsection{Primary Theory of Accounting Conservatism}

Watts (2003) identified a primary theory of accounting conservatism, contracting efficiency. This theory draws on agency theory (Jensen and Meckling, 1976) and identifies accounting conservatism as a mechanism that improves the ability of shareholders to better monitor their firms. 
Watts (2003) noted that investors rely on their agents to prepare financial information and that investors are likely to demand the adoption of accounting conservatism, so that agents are limited in their ability to prepare misleading financial information. Watts (2003) drew on Skinner (1994) and Watts and Zimmerman (1978) to identify taxation, regulation and lawsuit risk as drivers of the shareholder demand for accounting conservatism.

Qiang (2007) used a sample of 633 US firm-year observations from between 1988 to 1999 to examine four explanations for accounting conservatism, contracting, litigation, regulation, and taxation. In particular, Qiang (2007) investigated what factors motivate greater adoption of conditional and unconditional accounting conservatism. Qiang (2007) found, in line with Watts (2003), that contracting efficiency, tax, and regulation induce conditional accounting conservatism, while litigation risk induces both conditional and unconditional accounting conservatism.

\subsubsection{Alternative Theories of Accounting Conservatism}

The Watts (2003) contracting efficiency theory of accounting conservatism demand can be contrasted with alternative theories of accounting conservatism. McNichols (1988) proposed a compensation advantage theory for the demand for conservatism, noting that there can be a compensation advantage for managers when they withhold positive information from the market. Drawing on Healy (1985), McNichols (1988) noted that where managers have already met the higher bounds of their compensation plans they will have an incentive to maximize 
discretionary expenses and minimize discretionary revenues. In these circumstances, adopting accounting conservatism will result in the storage of undisclosed assets and overstated liabilities that could be reversed in future years to enhance compensation amounts that are not already maximized (McNichols, 1988). Furthermore, engaging in conservative reporting practices may result in the establishment of future compensation targets that are easier to achieve (McNichols, 1988).

Skinner (1994) used a random sample of 93 NASDAQ firms from the period 1981 to 1990 to study the voluntary disclosure practices of firms. Skinner (1994) found that managers are incentivized to engage in conservative accounting practices in order to protect their personal reputation and future employment opportunities, regardless of the benefits or costs of accounting conservatism for the firm (Skinner, 1994).

Kothari, Shu, and Wysocki (2009) used a sample of 7,044 dividend change announcements from the period 1962 to 2004 and a sample of 4,016 public management forecasts of quarterly earnings per share from the period 1995 to 2002, to study whether managers delay disclosure of bad news relative to good news. Consistent with Skinner (1994), Kothari et al. (2009) found that career issues and executive compensation contracts provide incentives for managers to adopt accounting conservatism.

\subsubsection{Measures of Accounting Conservatism}

Drawing on the Watts (2003) view of the demand for conservatism, certain financial characteristics are expected to provide insight into 
investor and debt holder demands for the adoption of accounting conservatism and can thus indicate adoption of accounting conservatis m.

Firm size is noted as an important indicator of accounting conservatis $m$ (Watts, 2003). In particular, Watts (2003) noted that larger companies are more likely to be mature, trusted, and have an analyst following. These features are likely to denote lower levels of shareholder information asymmetry, which is expected to result in a lower shareholder contracting demand for accounting conservatism (Easley, Hvidkjaer, and O'Hara, 2002; Watts, 2003). The literature has also found that companies which are larger in size are more likely to be targeted in a lawsuit by investors, as the expected lawsuit recovery rate is higher (Khan and Watts, 2009; Watts, 2003).

Other studies have put forward other rationales for the influence of firm size (Ge and McVay, 2005; Kinney and McDaniel, 1989). These studies note that larger companies tend to have stronger, more rigid accounting control systems. These rigid control systems may result in a reduced ability of management to apply their accounting judgments, which can lead to a reduction in the level of earnings management or accounting conservatism.

Leverage is noted within the literature as another important financial indicator of the adoption of accounting conservatism (Ahmed, Billings, Morton, and Stanford-Harris, 2002; Khan and Watts, 2009; Watts, 2003). Firms that have a higher level of leverage are theorized to be in a weaker bargaining position with debt holders than lower leveraged companies (Ahmed et al. 2002; Watts, 2003). Khan and Watts (2009) noted that as a result of this weaker firm bargaining position, lenders push for more 
conservative reporting behavior to reduce the level of information asymmetry between them and the firm. Thus, it follows that highly leveraged firms are more likely to adopt higher levels of accounting conservatism (Khan and Watts, 2009; Watts, 2003). Highly leveraged companies are also more likely to be engaged in a securities lawsuit and therefore may seek to mitigate this risk through the adoption of accounting conservatism (Khan and Watts, 2009). Ahmed et al. (2002) found evidence that firms engaging in accounting conservatism receive better debt ratings and thus can borrow at a reduced cost. WittenbergMoerman (2008) additionally found evidence that the bid ask spread in the secondary loan market is lower for borrowers that adopt accounting conservatism.

The market-to-book ratio is also identified as an important indicator of adoption of accounting conservatism (Khan and Watts, 2009). The literature notes that the market-to-book ratio acts as a financial proxy for firm growth options, which companies may have in addition to their book assets (Khan and Watts, 2009; Smith and Watts, 1992; Watts, 2003). Smith and Watts (1992) argued that growth options are positively correlated to more information asymmetry and contracting inefficiencies. Thus, a higher market-to-book ratio is expected to indicate the adoption of accounting conservatism.

Using cash flow from operations as a proxy for firm profitability, Ahmed et al. (2002) linked higher firm profitability to investor demand for conservatism. However, Ahmed and Duellman (2013) reached a different conclusion, finding a negative association between cash flow from operations and accounting conservatism. 
Ahmed et al. (2002) found that revenue volatility creates possible conflicts of interest between bondholders and shareholders over dividends. Ahmed et al. (2002) noted that higher revenue volatility indicates greater demand for conservatism from bondholders. Ahmed et al. (2002) also found that higher sales growth leads to higher inventory and accounts receivable, resulting in the adoption of conservatism.

GAAP requires conservative treatment of research and development expenses and therefore these expenses are identified in the literature as linked to the adoption of accounting conservatism (Ahmed and Duellman, 2013; Watts, 2003).

Reduced return on assets is noted in the literature as indicative of the adoption of accounting conservatism, as conservative firms tend to write off investments faster (Basu, 1997). Industry (Wittenberg-Moerman, 2008), credit ratings (Beatty, Weber, and Yu, 2008), and business cycles (Ryan, 2006) are also regarded as influences on the adoption of accounting conservatism.

Basu $(1995 ; 1997)$ introduced a measure of accounting conservatism that examined the timeliness with which bad news is reflected in earnings over good news. Basu $(1995 ; 1997)$ used a sample of 43,118 US firmyears during the period 1963 to 1990, to test for the adoption of accounting conservatism. Basu $(1995 ; 1997)$ found that bad news is reflected in earnings faster than good news, implying that firms adopted accounting conservatism in their financial reporting. Basu $(1995$; 1997) additionally found, over the three decades of the sample, that firms increased their level of accounting conservatism. 
Ball and Shivakumar (2005) investigated the adoption of accounting conservatism by public and private firms. Ball and Shivakumar (2005) used a sample of 196,427 firm-year observations from private and public companies in the UK from the period 1989 to 1999. Ball and Shivakumar (2005) adopted the Basu (1997) time-series measure of accounting conservatism and found that private firms have a lower level of accounting conservatism then public firms. Ball, Kothari, and Robin (2000) also found that private companies adopt lower levels of accounting conservatism than public companies. The authors theorized that the cause of this difference is lower investor demand for conservative reporting behavior by private firms.

Ryan (2006), in a review of the literature on the measurement of asymmetric timeliness in earnings, noted that measures of asymmetric timeliness have a number of limitations including, (a) firm returns are not equivalent to news, (b) conditional conservatism is pre-empted by unconditional conservatism, (c) there are instances where GAAP disallows conditional conservatism, (d) it can be challenging to measure asymmetric timeliness because of aggregation of news in a period, (e) there may be economic causes for asymmetric timeliness results, (f) big bath and cookie-jar reserves also affect the measurement of asymmetric timeliness, and ( $\mathrm{g}$ ) asymmetric timeliness is not consistent over time (Givoly, Hayn, and Natarajan, 2007). However, Ryan (2006) found that the Basu (1997) measure of asymmetric timeliness remains the best measure of conditional accounting conservatism.

Roychowdhury and Watts (2007) examined the link between two extensively used measures of conservatism: the asymmetric timeliness of earnings and the market-to-book ratio. Roychowdhury and Watts (2007) 
noted that previous literature has documented a negative association between these measures of conservatism with no theory to explain why. Roychowdhury and Watts (2007) used a sample of US 45,664 firm-year observations over the period 1972-1999, and documented a negative association over a one year period. Roychowdhury and Watts (2007) then tested the association over two years and beyond, finding that the association between the ratio of market-to-book and the asymmetric timeliness of earnings is positive over the longer period of time. Roychowdhury and Watts (2007) explained this difference by noting that when asymmetric timeliness of earnings is measured over short periods of one year or less, the asymmetric timeliness measure has a strong dependence on the beginning of period equity value. The authors noted that the beginning of period equity value is responsible for the negative association between firm asymmetric timeliness of earnings and the ratio of market-to-book. Roychowdhury and Watts (2007) also noted that the asymmetric timeliness of earnings appears to measure accounting conservatism more efficiently when estimated cumulatively over multiple years.

Dietrich, Muller, and Riedl (2007) examined the validity of the Basu (1997) measurement of asymmetric timeliness of earnings. Dietrich et al. (2007) used a sample of 92,380 US firm-year observations, from the period 1963 to 1990 and a simulated matching data set which was constructed to remove any relation arising from earnings asymmetrically incorporating bad news relative to good news. Dietrich et al. (2007) found evidence of asymmetric timeliness of earnings in the actual and the simulated data series and, as a result, found that the Basu (1997) measure of asymmetric timeliness of earnings results in test statistics which are biased towards the detection of accounting conservatism. 
Givoly et al. (2007) reviewed the measurement of asymmetric timeliness of earnings. The authors used a sample of 131,920 US firm-year observations from the period 1951 to 2000 to identify three factors which are unrelated to accounting conservatism but influence the Basu (1997) measurement of asymmetric timeliness of earnings. Firstly, the aggregation effect, or the concern that smaller firms disclose less information and therefore tend to disclose information around their earnings announcement date. This contrasts with large firms which tend to release more information during the year, leading to greater aggregation of information. The greater aggregation of information is expected to lead to a lower level of asymmetric timeliness for large firms compared with smaller firms adopting a similar level of conservatism. Secondly, economic events, which is the concern that the Basu (1997) measure of asymmetric timeliness of earnings interprets positive and negative economic events as signs of changes in the adoption of conservatism. Thirdly, disclosure policy, which is the concern that public announcements influence the Basu (1997) measure of asymmetric timeliness of earnings and lead to incorrect indications of adoption of accounting conservatism.

Khan and Watts (2009) noted that the Basu (1997) measure of accounting conservatism does not provide a firm-year measure. Khan and Watts (2009) used the Basu (1997) measure as well as known determinants of accounting conservatism (Watts, 2003) to calculate a new firm-year accounting conservatism measure and good news timeliness measure. Khan and Watts (2009) tested this measure on a sample of 115,516 US firm-year observations, from the period 1963 to 2005. 
Khan and Watts (2009) found that their new conservatism measure was robust, in particular, noting that firms with a higher firm-year measure of accounting conservatism had a correspondingly high level of Basu (1997) asymmetric timeliness, more negative return on assets, more variable non-operating accruals and a higher litigation risk. Khan and Watts (2009) noted that, when using their measure of accounting conservatism, failing to control for the ratio of market-to-book, size or leverage may result in an incorrect finding of an association between conservatis $m$ and the variable of interest.

\subsubsection{Accounting Conservatism and Lawsuit Risk}

Managers and directors have three strong incentives to reduce the risk of a future securities lawsuit. The first is to avoid damages arising from the securities lawsuit (Beck and Bhagat, 1997). The second is to secure the positions of their board and executive (Baum, Bohn, and Chakraborty, 2016) and the third is to avoid undesirable firm visibility and exposure to regulator actions (Watts and Zimmerman, 1978).

Skinner (1994) reasoned that when bad news is drip fed in the form of ongoing disclosure, there is less likelihood of an understatement of earnings and a subsequent negative stock decline. Skinner (1994) argued that managers are incentivised to reduce securities lawsuit risk by preempting large negative earnings surprises and disclosing information early.

Bushman and Piotroski (2006) used a sample of 86,927 firm-years drawn from 38 countries, during the period 1992 to 2001, to investigate financial reporting incentives. Bushman and Piotroski (2006) provided 
evidence that supports the argument that the adoption of accounting conservatism is used to reduce securities lawsuit risk and that firms in countries which provide stronger investor protection and a more effic ient judicial system, adopt higher levels of accounting conservatism.

Blunck (2009) also considered whether the adoption of accounting conservatism reduces lawsuit costs and found evidence that firms adopting higher levels of accounting conservatism face reduced litigation costs. Ettredge et al. (2015), built on the work of Blunck (2009) using a sample of 363 US firms subject to a securities lawsuit alleging a violation of GAAP from 1996 to 2011, and a matching sample of firms not subject to a securities lawsuit. Ettredge et al. (2015) found that firms which adopted a higher level of accounting conservatism can both mitigate the occurrence of future securities lawsuits and reduce the severity of lawsuit outcomes.

It is clear from the literature that the adoption of higher levels of accounting conservatism can reduce firm securities lawsuit risk. It is also clear that firms which believe that they have a higher lawsuit risk are incentivised to adopt accounting conservatism in an effort to mitigate this risk (Skinner, 1993; Rogers and Van Buskirk, 2009).

\subsection{Firm Disclosure and Securities Lawsuit Risk}

Voluntary firm announcements and financial misstatements are often noted as the cause of securities lawsuits taken under SEC rule 10b-5. 


\subsubsection{Firm Announcements and Securities Lawsuits}

Prior research into US securities lawsuits has found evidence of a strong link between firm earnings disclosures and the probability of being engaged in a securities lawsuit (Rogers et al. 2011; Skinner, 1994, 1997). Skinner (1994), used a random sample of 93 publicly listed firms between 1981 and 1990, to investigate the relationship between voluntary earnings disclosures and the risk of being targeted in a securities lawsuit under SEC rule 10b-5. Skinner (1994) found evidence that the US securities regime incentivizes managers to pre-empt large negative earnings surprises by voluntarily disclosing negative earnings at an earlier stage, in order to avoid greater lawsuit losses and personal reputation damage. Skinner (1994) noted that this incentive is not present for positive earnings surprises, incentivizing managers to recognize bad news ahead of good news in voluntary disclosures.

Francis et al. (1994) used a sample of 45 firms during the period 1988 to 1992 from four high litigation industries; computers, electronics, biotechnology and retailing, as well as a matching sample of firms to investigate a possible link between negative earnings announcements and reduced lawsuit risk. Francis et al. (1994) found evidence that prior and concurrent earnings disclosures may reduce the severity of future securities lawsuits. However, Francis et al. (1994) did not find evidence to support the Skinner (1994) conclusion that firms which disclose bad news asymmetrically over good news will be subject to lower levels of lawsuit risk.

Baginski, Hassell, and Kimbrough (2002) tested the frequency and characteristics of earnings forecasts across the US and Canadian legal 
regimes. Baginski et al. (2002) used a sample of 115,751 Canadian and US firm-years, a sample of 164 US earnings forecasts, and a sample of 219 Canadian earnings forecasts, from the period 1993 to 1996. Baginski et al. (2002) found that US firms provide fewer earnings forecasts then Canadian firms. Baginski et al. (2002) also found that US firms are more likely to issue negative earnings forecasts than Canadian firms. The authors noted that these findings support the theory that managers provide more conservative earnings management forecasts in high litigation environments.

Johnson, Kasznik, and Nelson (2001) used a sample of 523 US firms from the computer hardware, computer software, and pharmaceutical industries to investigate whether the PSLRA (1995) influenced firm voluntary disclosure. The authors found that the PSLRA (1995) resulted in reduced securities lawsuit risk and a subsequent increase in the frequency of firm sales and earnings forecasts.

Field, Lowry, and Shu (2005) investigated the link between voluntary disclosures and securities lawsuits, using a sample of 78 firms subject to a securities lawsuit, from the period 1996 to 2000. Field et al. (2005) controlled for endogeneity between disclosure and litigation risk and found, contrary to Johnson et al. (2001), that voluntary disclosures lower securities lawsuit risk. Field et al. (2005) noted that the differe nce between their results and Johnson et al. (2001) is at least partly due to the prior work suffering from endogeneity concerns between disclosure and litigation risk.

Brown, Hillegeist, and Lo (2005) used a sample of 23,901 management forecasts and 972 securities lawsuits, from the period 1996 to 2002, to 
investigate how lawsuit risk influences earnings disclosures. Brown et al. (2005) found that securities lawsuit risk is positively linked with the likelihood of issuing a forecast for both good-and bad-news firms and that this link is stronger for firms with negative earnings announcements. The authors also found that increased litigation risk is linked with forecasts being released earlier and being more detailed.

Cao and Narayanamoorthy (2011) investigated the effects of litigation risk on earnings management announcements. Cao and Narayanamoorthy (2011) use a sample of 759 earnings announcements made by 124 firms over the period 2001 to 2002. Cao and Narayanamoorthy (2011) found, consistent with Brown et al. (2005), that firms tend to issue earnings forecasts earlier during bad news periods. Cao and Narayanamoorthy (2011) also found, contrary to Brown et al. (2005), that firms do not behave differently with respect to forecast horizon in good news periods.

Rogers et al. (2011) examined firm market disclosures, studying the relationship between disclosure tone and securities lawsuit risk, to determine whether the use of optimistic language increases securities lawsuit risk. Rogers et al. (2011) examined 827 disclosure-related shareholder lawsuits, during the period 1996 to 2005, and used both a general-purpose dictionary and a context-specific text dictionary to measure the tone of general disclosures. The authors found that firms with voluntary earnings announcements, that were unusually optimistic in tone, were more likely to be sued compared to other firms in the same economic position. 
Donelson, McInnis, Mergenthaler, and Yu (2012) investigated whether the timely revelation of bad earnings news is associated with lower litigation risk. Donelson et al. (2012) used a sample of 408 firms subject to a class action lawsuit during the period 1996 to 2005 and a matching sample of non-sued firms. The authors compared earnings news timeliness between sued and non-sued firms. Donelson et al. (2012) found, in line with Field et al. (2005), that earlier revelation of bad earnings news lowers firm securities lawsuit risk. Donelson et al. (2012) noted that this result holds for both settled and dismissed lawsuits.

\subsubsection{Financial Reporting and Securities Lawsuit Risk}

Blunck (2009) examined a sample of 704 US securities lawsuits and a matching sample of non-sued firms. Blunck (2009) found evidence that aggressive financial reporting is associated with increased securities litigation risk. Blunck (2009) further noted that the evidence suggests that the plaintiff's decision to file a lawsuit is partially dependent on the level of accounting conservatism in the period leading up to the litigation.

Chalmers et al. (2012) used a sample of 359 US firms for the period 1988 to 2000 , which were subject to a securities lawsuit and a matching sample of firms not subject to a securities lawsuit, to investigate how firm financial disclosures affects the likelihood of being engaged in a securities lawsuit. Chalmers et al. (2012) found that firms which had inflated earnings were more likely to be targeted with a securities lawsuit. Chalmers et al. (2012) applied the Dechow and Dichev (2002) measure of earnings quality and further found that sued firms had a lower level of earnings quality in the period before they were sued, when compared to the matching sample. Chalmers et al. (2012) noted that these findings 
highlight the importance of firm financial reporting as a determinant of securities lawsuits.

\subsection{Lawsuit Risk Evaluation following a Securities lawsuit}

Rogers and Van Buskirk (2009) theorized that the level of securities lawsuit risk is assessed subjectively by firm management and is thus subject to managerial bias. Rogers and Van Buskirk (2009) also theorize that when a firm has been engaged in a securities lawsuit, the management of the firm will be biased towards assessing securities lawsuit risk at a higher level. Drawing on this theory, Rogers and Van Buskirk (2009) hypothesized that, following a securities lawsuit, management will upwardly revise their current level of perceived securities lawsuit risk and subsequently change their market announcements as a result of the higher level of perceived lawsuit risk (Rogers and Van Buskirk, 2009).

Rogers and Van Buskirk (2009) investigated this theory of firm disclosure by using a sample of 827 US firms from the period 1996 to 2005, which were subject to a disclosure-related securities lawsuit. Rogers and Van Buskirk (2009) examined the frequency of firm announcements, conference call frequency, and earnings forecasts. The authors found that firms responded to a securities lawsuit by decreasing their market announcements. Rogers and Van Buskirk (2009) noted that because each additional disclosure created an additional level of lawsuit risk, rather than improving the quality of their voluntary disclosures to reduce information asymmetry, firms instead limited their disclosures. 
Rogers and Van Buskirk (2009) concluded that firms do upwardly revise their current level of perceived securities lawsuit risk following a securities lawsuit and subsequently reduce their voluntary disclosures. Securities lawsuits under SEC rule 10b-5 are, as such, expected to lead to a managerial bias towards assessing securities lawsuit risk at a higher level, with the higher level of securities lawsuit risk expected to influe nce firm disclosure strategy.

\subsection{Govemance Change Following a Securities Lawsuit}

Rogers and Van Buskirk (2009) also argued that, following a securities lawsuit, firm governance arrangements are likely to change as a result of directors and executive officers either voluntarily leaving the firm, or failing to renew their tenure. Rogers and Van Buskirk (2009) highlighted that these new board and executive members were expected to bring unique skills and perspectives on risk evaluation. As such, governance turnover is expected to lead to different firm evaluations of the risk environment and these new risk evaluations are likely to directly affect firm disclosure policy, including managerial decisions surrounding the adoption of accounting conservatism.

Romano (1991) theorized that a potential role of securities lawsuits is to identify managers who have failed in their duties to shareholders. Romano (1991) used a sample of 535 US firms subject to securities lawsuit during the period 1960 to 1987 and a matching sample of nonsued firms, to investigate the impact of securities lawsuits on governance. Romano (1991) found that senior executive turnover is higher in firms that are subject to a securities lawsuit and argued that the higher 
executive turnover is related to the underlying problems that gave rise to the securities lawsuit, rather than the securities lawsuit itself.

Strahan (1998) investigated CEO turnover, using a sample of 309 US firms, which were subject to a securities lawsuit during the period 1991 to 1996. Strahan (1998) found, consistent with the findings of Niehaus and Roth (1999), that CEO turnover increases following a securities lawsuit, even after controlling for other factors linked to securities lawsuits, such as single-day stock price declines.

Agrawal, Jaffe, and Karpoff (1999) used a sample of 103 US firms from the period 1981 to 1992 , which were reported in the fraud and crime listings in the general news section of the Wall Street Journal Index as involved in corporate fraud. Agrawal et al. (1999) also used a matched sample of firms, not identified as subject to corporate fraud, to study managerial turnover following firm involvement in fraud. Agrawal et al. (1999) found evidence that firms engaging in fraud have an incrementally higher level of executive turnover but that finding was not present after controlling for other firm attributes.

Srinivasan (2005) used a sample of 409 US firms that restated their earnings during the period 1997 to 2001, to examine the consequence of a financial restatement on outside directors. Srinivasan (2005) found that there are limited financial penalties arising from public enforcement taken by the Securities and Exchange Commission (SEC), however there are significant labour market penalties. In particular, Srinivasan (2005) found that for firms that overstate earnings, director departure increases according to the restatement severity. Notably, Srinivasan (2005) found 
that the director departure rate is incrementally higher for directors who were members of an audit committee.

Persons (2006) examined the impact of securities lawsuits on executive turnover and compensation. Persons (2006) used a sample of 224 US firms collected from the Wall Street Journal index from 1992 to 2000 and a matching sample of non-sued firms. Persons (2006) found that firms have a significantly higher executive turnover following a securities lawsuit. Persons (2006) also found that CEO turnover is higher, when the CEO was not the chair of the board, or the CEO recently joined the board.

Fich and Shivdasani (2007) examined changes to director tenure following a securities lawsuit using a sample of 216 firms, from the period 1998 to 2002. Fich and Shivdasani (2007) removed any lawsuits alleging insider trading from their sample, to focus on the influence of securities lawsuits alleging financial misrepresentations. The authors found that firms with an outside director who also sits on the board of another sued firm have a significantly higher probability of being subject to a securities lawsuit. Fich and Shivdasani (2007) additionally found that there is no evidence of higher board turnover in the boards of firms subject to a class action lawsuit, however, they did find a significant decline in the number of board appointments held by directors who are on the board of a firm subject to a securities lawsuit.

Cheng, Huang, Li, and Lobo (2010) investigated whether lawsuit plaintiff type influences board turnover, using a sample of 525 US sued firms, from 1996 to 2005. Cheng et al. (2010) found evidence that, when the lead plaintiff is an institutional investor, firms increase their overall 
board independence following the lawsuit. Cheng et al. (2010) also found that defendant firms with institutional plaintiffs increased their board independence in the period directly before the securities lawsuit was filed.

McTier and Wald (2011) used a sample of 910 US sued firms, from the period 1996 to 2005, to investigate the impact of securities lawsuits on financing choices, overinvestment decisions and firm governance. McTier and Wald (2011) found that there is an association between a firm being sued and the appointment of a new CEO.

Amoah (2013) used a sample of 93 US sued firms, from the period 1997 to 2005. Amoah (2013) found a positive link between the size of a lawsuit penalty and the probability of CEO turnover. Amoah (2013) also found that a larger lawsuit penalty is linked to earlier CEO turnover.

Baum et al. (2016) used a sample of 333 US sued firms, from the period January 1996 to 2003 to investigate the influence of securities lawsuits on insider and outsider director turnover. Baum et al. (2016) examined the board make-up of firms over four years following on from a securities lawsuit to ensure that the term of every firm director in their sample expired at least once. Baum et al. (2016) found that the effects of a securities lawsuit differed between outsider and insider directors with outsider directors more likely to depart. Baum et al. (2016) also found that director turnover rates are higher when lawsuits are settled relative to when lawsuits are dismissed. 
Agrawal and Cooper (2017) investigated the impact of accounting scandals on top management, financial officers and outside auditors. Agrawal and Cooper (2017) used a sample of 518 US publicly listed firms that had announced downwards earnings restatements during the period 1997-2002, and a matching sample of firms which did not make restatements. Agrawal and Cooper (2017) found evidence of increased CEO and CFO turnover in the firms which had made the earnings decreasing restatements.

Gao, Kim, Tsang, and Wu (2017) used a sample of 195 sued US firms, and a matching sample of non-sued firms from the period 1997 to 2007, to investigate whether outside directors are aware of financial fraud during the period of time that fraud was alleged in a securities lawsuit. Gao et al. (2017) used outside director turnover as a proxy for awareness. Gao et al. (2017) found that outside director turnover is higher in the sample of firms engaging in financial fraud during the time of the alleged fraud. Gao et al. (2017) additionally found that female directors, directors with large stock ownership, and directors with more directorships at other companies were more likely to depart during the alleged fraud committing period. The findings of this study support the notion that outside directors have the ability to detect financial fraud during the fraud committing period, and that outside director turnover may rise as a consequence of the lawsuit conduct, rather than the lawsuit itself.

In summary, it is clear that, following a securities lawsuit, firms in the US are likely to experience a higher than average amount of change on their board and in their pool of executive officers. Turnover in director and executive officers' roles is expected to lead to new managerial 
perspectives on securities lawsuit risk and new firm disclosure strategies surrounding the adoption of accounting conservatism (Rogers and Van Buskirk, 2009).

\subsection{Anticipation of a Securities Lawsuit}

Cheng et al. (2010) also noted that firms may respond to a securities lawsuit and consequently implement changes to their governance arrangements in the period before a securities lawsuit is filed. As such, there is uncertainty regarding whether firms will change their behavior following a securities lawsuit or following the conduct which will go on to give rise to a securities lawsuit (Cheng et al. 2010).

\subsection{Statement of Hypothesis One and Hypothesis Two}

Section 3.6 established that securities lawsuit risk is subjectively evaluated by firm management and directors and thus subject to managerial bias. Furthermore, section 3.6 noted that when a firm is engaged in a securities lawsuit, the management and directors of that firm will be biased towards assessing securities lawsuit risk at a higher level. Higher securities lawsuit risk is documented in section 3.5, as being associated with firm general and financial disclosures decisions, and in section 3.5.3, as incentivising management and directors to adopt accounting conservatism. Additionally, section 3.7 noted that following a securities lawsuit there is expected to be greater director and executive officer turnover, which brings new perspectives and skills leading to different assessments of securities lawsuit risk. 
In section 3.8, Cheng et al. (2010) noted that firms may anticipate securities lawsuits based on their behaviour and subsequently make changes to their governance in advance of the securities lawsuit. To ensure the influence of securities lawsuits are captured, the anticipatory period following lawsuit conduct is examined, along with the period following the filing of the securities lawsuit. Drawing on this literature, this study offers the following hypotheses:

H1: Following the conduct that gave rise to a lawsuit, taken under SEC rule $10 \mathrm{~b}-5$, firms adopt a higher level of conservatism.

$\mathrm{H} 2$ : Following the filing of a securities lawsuit, taken under SEC rule 10b-5, firms adopt a higher level of conservatism.

\subsection{Corporate Governance and Accounting Conservatism}

Prior literature has reported on corporate governance as a possible determinant of accounting policy choice (Bushman, Chen, Engel, and Smith, 2004). This study reviews the literature on corporate governance as measured by audit fees, board size, number of board meetings, and the percentage of outside directors, on the firm adoption of accounting conservatism.

This study also examines the literature concerning the influence of corporate governance on securities lawsuit risk, the influence of corporate governance mechanisms on other firm governance arrangements, and corporate governance turnover following a securities lawsuit. 


\subsubsection{Audit Fees}

Gul, Srinidhi, and Shieh (2004) examined the impact of the financial downturn associated with the Asian financial crisis on the adoption of accounting conservatism and audit fees. Gul et al. (2004) used a sample of 2,061 Hong Kong publicly listed firms, from the period 1990-1997 and found that during the financial downturn period (1996-1997) the level of accounting conservatism by firms decreased. Gul et al. (2004) further found that, with the reduced adoption of accounting conservatism, there was a subsequent increase in firm audit fees.

Seetharaman, Gul, and Lynn (2002) examined firm audit fees for UK firms cross listed on the US market. Using a sample of 550 firms collected from the period 1996 to 1998, Seetharaman et al. (2002) found that UK auditors charge higher fees for their services when their clients are cross listed in the US, but not when they are cross listed in non US capital markets. Seetharaman et al. (2002) concluded that this is likely due to the differences across liability regimes.

Carcello, Hermanson, Neal, and Riley (2002) used a sample of 258 US firms from the period April 1992 to March 1993, to investigate the influence of audit fees on corporate governance arrangements. Carcello et al. (2002) found that board independence, the number of board meetings and the number of outside directorships held by directors were all positively correlated with firm audit fees. Carcello et al. (2002) argued that their results are consistent with more independent, diligent and expert boards promoting shareholder interests by purchasing more in depth audit services. 
Abbott, Parker, Peters, and Raghunandan (2003) investigated the link between the composition of the firm audit committee and audit fees, examining 492 firms from 2001. Abbott et al. (2003) found that when the audit committee is made up of outside directors and has at least one member with financial expertise, there is an associated reduction in firm audit fees.

Yatim, Kent, and Clarkson (2006) examined governance structures, ethnicity and audit fees using a sample of of 736 Malaysian listed firms from the year 2003. Yatim et al. (2006) found that external audit fees are positively associated with board independence, audit committee expertise and the frequency of audit committee meetings.

Habib, Jiang, Bhuiyan, and Islam (2014) surveyed the literature concerning the consequences of securities lawsuits against auditors and, in particular, examined the impact on reporting quality. Habib et al. (2014) concluded that securities lawsuits against auditors are linked to increases in audit fees.

Lee, $\mathrm{Li}$, and Sami (2014) examined the impact of conditional conservatism on audit fees and the influence of corporate governance. Lee et al. (2014) theorized that conditional conservatism reduces audit lawsuit risk and should thus reduce audit cost. Using a sample of 41,537 firm-year observations, from the period 2004 to 2009, Lee et al. (2014) found evidence that firms with higher levels of conditional accounting conservatism had lower audit costs. Additionally, Lee et al. (2014) found evidence that higher corporate governance quality, as measured by CEO duality, the portion of executives on the board and the number 
of board meetings, moderates the association between audit fees and accounting conservatism.

DeFond, Lim, and Zang (2015) investigated auditor response to conservative reporting practices. DeFond et al. (2015) used a sample of 27,748 firm-year observations and a financially distressed sample of 9,284 firm-year observations, from the period 2000 to 2010. DeFond et al. (2015) found evidence consistent with Lee et al. (2015), that the auditors of firms which adopt higher levels of accounting conservatis $m$ charge lower fees, issue fewer going concern opinions, and resign less frequently. DeFond et al. (2015) argued that these findings are consistent with increased client accounting conservatism resulting in reduced audit engagement risk.

\subsubsection{Board Size}

Prior research has examined the influence of board size on the adoption of accounting conservatism and provides two competing views. The first view is that larger boards are less effective in monitoring the firm executive then smaller boards, leading to lower levels of accounting conservatism. This reduced effectiveness is theorized to occur due to difficulties in coordinating and managing a larger group (Jensen and Meckling, 1976) and increased free rider concerns, as directors may rely on other directors to monitor the executive (Hermalin and Weisbach, 2003).

The second view is that larger boards allow directors to specialize, with directors able to focus on doing fewer tasks to a higher standard (Klein, 2002). Larger boards are also expected to have more experienced 
directors (Xie, Davidson, and Dadalt, 2003). The increased skill set and ability to specialize is predicted to lead to more effective monitoring of the executive and the increased adoption of accounting conservatis $m$ (Ahmed and Henry, 2011; Klein, 2002; Xie et al. 2003).

Yermack (1996) examined a sample of 452 U.S. industrial firms during the period 1984 to 1991. David Yermack (1996) found an inverse link between board size and firm value, consistent with the theory that small boards of directors are more efficient.

Uzun, Szewczyk, and Varma (2004) used a sample of 133 US firms from the period 1978 to 2001 , to investigate whether board of directors characteristics, including board size, influence corporate fraud. Uzun et al. (2004) found no association between board size and corporate fraud.

Gillan (2006) reviewed the literature on corporate governance, defined corporate governance and presented a corporate governance framework. The framework provided considers the role of internal governance and external governance. Gillan (2006) finds that the literature is moving to adopt composite corporate governance mechanisms and that the interactions between governance variables are becoming more important to researchers.

Ahmed and Duellman (2007) used a sample of 306 US firms from the period 1999 to 2001 to investigate potential links between corporate governance and the adoption of accounting conservatism. In particular, Ahmed and Duellman (2007) examined whether board size is associated with the adoption of accounting conservatism but found no evidence of a link. 
Larcker, Richardson, and Tuna (2007) undertake a comprehensive assessment of firm governance variables, examining the links between those variables and firm performance. Larcker et al. (2007) used a sample of 2,126 firm-years between the years 2002 to 2003. Larcker et al. (2007) find their set of governance variables have modest associations with corporate outcomes which they considered either to be the result of poor measures of corporate governance or the low explanatory power of corporate governance.

Lara et al. (2009) tested for an association between a corporate governance composite variable, which incorporates a takeover protection index (Gompers, Ishii, and Metrick, 2003) and a range of internal governance variables, including board size, and accounting conservatism. Lara et al. (2009) used a sample of 9,152 US firm-years, from between 1992 and 2003, and found that the corporate governance composite variable is positively associated with the level of accounting conservatism. Lara et al. (2009) additionally noted that the internal and external governance mechanisms are expected to have a complementary effect on the monitoring of the executive and the greater adoption of accounting conservatism.

Lim (2011) used a sample of 644 Australian listed firms in 1998, and 774 Australian listed firms in 2002 to investigate the influence of corporate governance on accounting conservatism. In particular, Lim (2011) investigated a possible link between board size and accounting conservatism but finds no evidence of an association. 


\subsubsection{Board Meetings}

Vafeas (1999) examined 307 US firms over the period 1990 to 1994 to investigate a possible link between board meeting frequency and corporate governance. Vafeas (1999) found that the frequency of board meetings is linked to total director monitoring effort and firm value.

Chen, Firth, Gao, and Rui (2006) used a sample of 162 Chinese firms, from the period 1999 to 2003, that were subject to a securities enforcement order by the Chinese Securities Regulatory Commission (CSRC) to investigate whether corporate governance, such as board meetings, influences the likelihood of financial fraud occurring within a firm. Chen et al. (2006) found evidence that more frequent board meetings are positively linked to increased securities enforcement indicating that firms may hold additional meetings to discuss problematic activity.

Lara et al. (2009) also included the frequency of board meetings in their corporate governance composite variable and found evidence of a positive association between the composite corporate governance variable and accounting conservatism.

\subsubsection{Board Independence}

Independent directors are theorized to pursue accounting policies which benefit a larger range of shareholders, in particular, seeking to lower information asymmetry between the firm and its shareholders (Watts, 2003). Adopting greater levels of accounting conservatism is one possible method for achieving reduced information asymmetry. As such, 
more independent boards are expected to engage in higher levels of accounting conservatism (Watts, 2003).

Beekes, Pope, and Young (2004) investigated the influence of board independence on earnings quality and accounting conservatism. Beekes et al. (2004) used a sample of 508 UK firms from the period 1993 to 1995. Beekes et al. (2004) found evidence that firms with a higher proportion of outside directors adopted higher levels of accounting conservatism.

Bushman, Chen, Engel, and Smith (2004) used a sample of 784 US firms from the Fortune 1000 list to investigate the influence of corporate governance and earnings timeliness. Bushman et al. (2004) found evidence inconsistent with Beekes et al. (2004) research, finding instead that when accounting conservatism is low, boards embrace stronger governance mechanisms, such as board independence.

Helland and Sykuta (2005) used a sample of 692 US firms that were subject to a securities lawsuit during the period 1988 to 2000, which were subject to a securities lawsuit, to investigate whether board independence influences securities lawsuit risk. Helland and Sykuta (2005) found that less independent boards are more likely to be subject to a securities lawsuit, and that a $1 \%$ increase in the proportion of inside directors has a $0.94 \%$ increase in the probability of the firm being sued.

Chen et al. (2006) also investigated whether including board independence influences the likelihood of financial fraud occurring within a firm. Chen et al. (2006) found evidence that firms with a higher 
proportion of insider directors are linked to a higher incidence of securities enforcement.

Ahmed and Duellman (2007) also examined board independence and found that greater board independence is associated with a higher level of accounting conservatism.

Lara et al. (2009) included board independence in their corporate governance composite variable and found a positive association between their composite governance variable and accounting conservatism.

Ahmed and Henry (2012) investigated whether selected corporate governance mechanisms, such as board independence, influences the level of accounting conservatism using a random sample of 120 publicly listed Australian listed firms, from the period 1992 to 2002. Ahmed and Henry (2012) found that more independent boards were linked to the greater adoption of unconditional accounting conservatism, but not conditional conservatism. The authors noted that this accounting conservatism policy choice may be a result of the unique low litigation environment of Australia.

Lim (2011) also investigated a link between board independence and accounting conservatism and found a positive association between the percentage of independent directors and the level of accounting conservatism. 


\subsection{Statement of Hypothesis Three and Four}

As described in section 3.10, corporate governance is expected to influence the adoption of accounting conservatism. As such, the following hypotheses are offered to test the moderating influence of corporate governance on the link between the adoption of accounting conservatism, following a securities lawsuit, or following conduct which is expected to give rise to a securities lawsuit.

H3: Corporate governance, as measured by (a) audit fees, (b) board size, (c) number of board meetings, and (d) the percentage of outside directors, moderates the relationship between the conduct that gave rise to a lawsuit, taken under SEC rule 10b-5, and firm adoption of a higher level of conservatism.

H4: Corporate governance, as measured by (a) audit fees, (b) board size, (c) number of board meetings, and (d) the percentage of outside directors, moderates the relationship between securities lawsuits, taken under SEC rule 10b-5, and firm adoption of a higher level of conservatism.

\subsection{Chapter Summary}

This chapter has reviewed the relevant literature on securities lawsuits and settlement, firm disclosure, agency problems, the adoption of a higher level of accounting conservatism, and firm governance. The research reviews the interdependencies between lawsuit risk, securities lawsuits, corporate governance and turnover, and the adoption of accounting conservatism. The research also lays out the theoretical 
framework of agency and contracting theory and the theoretical mechanisms which are expected to influence the adoption of accounting conservatism following a securities lawsuit.

Four important insights are identified from the literature reviewed. First, both market disclosures and financial disclosure are associated with firm securities lawsuit risk. Particularly influential in forming this view was Rogers and Van Buskirk (2009) who found empirical evidence of this link. Second, accounting conservatism can be adopted to ameliorate contracting concerns and problems of agency. This view was formed drawing primarily from Watts (2003). Third, firms may pre-empt the impact of a potential securities lawsuit in the period before the lawsuit was filed. Fourth, firms in the US are likely to experience a higher than average amount of change on their board and in their pool of executive officers following on from a securities lawsuit. This conclusion is supported by evidence from Fich and Shivdasani (2007) and Gao et al. (2017).

Three theoretical mechanisms are identified as influencing the adoption of accounting conservatism following on from conduct which gives rise to a securities lawsuit, and the filing of a securities lawsuit. First, that securities lawsuit risk is subjectively evaluated by firm management and directors and subject to managerial bias. Second, when a firm is engaged in a securities lawsuit, the management and directors of that firm are expected to be biased towards assessing securities lawsuit risk at a higher level. Third, higher perceived lawsuit risk is expected to incentivise management and directors to adopt accounting conservatism. Section 3.9 offers two hypotheses in light of the literature reviewed and theoretical mechanisms identified. 
Four corporate governance theoretical mechanism are identified as influencing the adoption of accounting conservatism. First, audit cost is linked to audit lawsuit risk, with lower audit costs linked to higher levels of firm accounting conservatism. Second, board size is associated with the total amount of resources available to the board, with a larger board better able to influence the adoption of a higher level of accounting conservatism. Third, board meetings are also associated with the total amount of resources available to the board, with more board meetings enabling the board to influence the adoption of a higher level of accounting conservatism. Fourth, more independent boards have a greater incentive to lower information asymmetry between the firm and its investors and are likely to adopt accounting conservatism to achieve this. Section 3.11 offers two hypotheses in light of the literature review and theoretical mechanisms identified. Chapter four describes the sample and research methodology used to test the hypothesis offered in this chapter. 


\section{CHAPTER FOUR: SAMPLE AND RESEARCH METHODOLOGY}

\subsection{Chapter Introduction}

This chapter reviews the research methodology used to test the study's hypotheses and the sample collected. The study uses multivariate regression analysis to test the impact of conduct leading to a lawsuit, and the filing of lawsuits, on the level of accounting conservatism. A number of prior studies have used a matching sample to study lawsuit consequences. However, a matching sample would require the use of size, the ratio of market-to-book and leverage as matching variables. In this study these variables serve as determinants of firm-year accounting conservatism (Khan and Watts, 2009). Thus, consistent with the methodology of Baum et al. (2016), this study only examines firms that have been subject to a securities lawsuit.

Section 4.2 examines the firm-year measure of accounting conservatis $m$ (Cscore) developed by Khan and Watts (2009). Section 4.3 discusses the securities lawsuit measures. Section 4.4 describes the test methodology and parameter sign predictions for hypothesis one and hypothesis two. Section 4.5 describes the selection of the study's sample and the sources of financial, governance, and securities lawsuit data. Section 4.6 describes the robustness tests for the hypotheses. In particular, use of lagged firm-year accounting conservatism, alternative securities lawsuit measures, and an alternative measure of accounting conservatism. Section 4.7 concludes the chapter. 


\subsection{Conservatism Measure}

Firm-level accounting conservatism (Cscore) is used as the primary measure of accounting conservatism. Following the Khan and Watts (2009) methodology, firm-year accounting conservatism (Cscore) and firm-year good news timeliness score (Gscore) are estimated in two steps.

Firstly, model 1 as specified in Table 4-2 is estimated for each year of the study period, 1999 to 2012.

Table 4-1: Model One

\begin{tabular}{|l|l|}
\multirow{4}{*}{ Model 1 } & $\begin{array}{l}X_{i, t}=a_{0}+a_{1} D_{i, t}+R_{i, t}\left(a_{2}+a_{3} \operatorname{Size}_{i, t}+a_{4} M B_{i, t}+a_{5} L e v_{i, t}\right)+R \_D_{i, t}\left(a_{6}+a_{7} R \_D \_S i z e_{i, t}+\right. \\
\left.a_{8} R \_D \_M B_{i, t}+a_{9} R \_D \_L e v_{i, t}\right)+a_{1} \operatorname{Size}_{i, t}+a_{11} M B_{i, t}+a_{12} L e v_{i, t}+a_{13} D \_S i z e_{i, t}+a_{14} D \_M B_{i, t}+ \\
a_{15} D \_L e v_{i, t}+\varepsilon_{i, t}\end{array}$ \\
\hline
\end{tabular}


Table 4-2: Model One Variable Definitions

\begin{tabular}{|c|c|}
\hline \multicolumn{2}{|r|}{ Panel A: Dependent Variables } \\
\hline $\bar{X}$ & Net income before extraordinary items, scaled by lagged market value of equity. \\
\hline \multicolumn{2}{|r|}{ Panel B: Independent Variables } \\
\hline$R$ & $\begin{array}{l}\text { The firm's monthly compounded returns, st arting } 4 \text { months after fiscal year end } \\
\text { and accumulating over } 12 \text { months, following the Basu }(1995 ; 1997) \\
\text { methodology. }\end{array}$ \\
\hline$D$ & Dummy variable equal to 1 if $R$ is negative and zero if $R$ is positive. \\
\hline Size & The natural log of market value of equity. \\
\hline$M B$ & The market-to-book ratio. \\
\hline Lev & The sum of long-term and short-term debt divided by market value of equity. \\
\hline R_Size & $R$ interacted with Size. \\
\hline$R \_M B$ & $R$ interacted with the $M B$. \\
\hline$R \_L e v$ & $R$ interacted with Lev. \\
\hline$R \_D$ & $R$ interacted with $D$. \\
\hline D_Size & $D$ interacted with Size. \\
\hline $\bar{D} \_M B$ & $D$ interacted with $M B$. \\
\hline D_Lev & D interacted with Lev. \\
\hline$R \_D \_S i z e$ & $R$ interacted with $D$ and interacted with Size. \\
\hline$R \_D \_M B$ & $R$ interacted with $D$ and interacted with $M B$. \\
\hline$R \_D \_L e v$ & $R$ interacted with $D$ and interacted with $L e v$. \\
\hline
\end{tabular}

Secondly, the yearly means of the annual regression coefficients resulting from the estimations of model 1 are used to calculate the firmyear level of accounting conservatism (Cscore), and the firm-year level of good news timeliness (Gscore), for each firm-year, as specified in equations one and two below. 
Equation 1 Cscore $_{\mathrm{i}, \mathrm{t}}=\mathrm{a}_{6, \mathrm{t}}+\mathrm{a}_{7, \mathrm{t}} \operatorname{Size}_{\mathrm{i}, \mathrm{t}}+\mathrm{a}_{8, \mathrm{t}} \mathrm{MB}_{\mathrm{i}, \mathrm{t}}+\mathrm{a}_{9, \mathrm{t}} \operatorname{Lev}_{\mathrm{i}, \mathrm{t}}$

Equation 2 Gscore $_{\mathrm{i}, \mathrm{t}}=\mathrm{a}_{2, \mathrm{t}}+\mathrm{a}_{3, \mathrm{t}} \operatorname{Size}_{\mathrm{i}, \mathrm{t}}+\mathrm{a}_{4, \mathrm{t}} \mathrm{MB}_{\mathrm{i}, \mathrm{t}}+\mathrm{a}_{5, \mathrm{t}} \operatorname{Lev}_{\mathrm{i}, \mathrm{t}}$

Equation one and two are linear functions of the firm characteristics, Size, MB and Lev. Equation one indicates the incremental timeliness of bad news over good news, while equation two indicates the incremental timeliness of good news over bad news.

\subsection{Securities Lawsuit Variables}

To test hypothesis one and two, this study constructs two disclosurerelated securities lawsuit variables, Lawsuit Conduct $(L C)$ and Lawsuit Filing $(L F)$ based on the start of the lawsuit conduct period and the lawsuit filing date. Figure 4-1 shows the median period between the lawsuit conduct start date, the lawsuit conduct end date and the lawsuit filing date.

\section{Figure 4-1: Lawsuit Conduct Period and Lawsuit Filing Date}

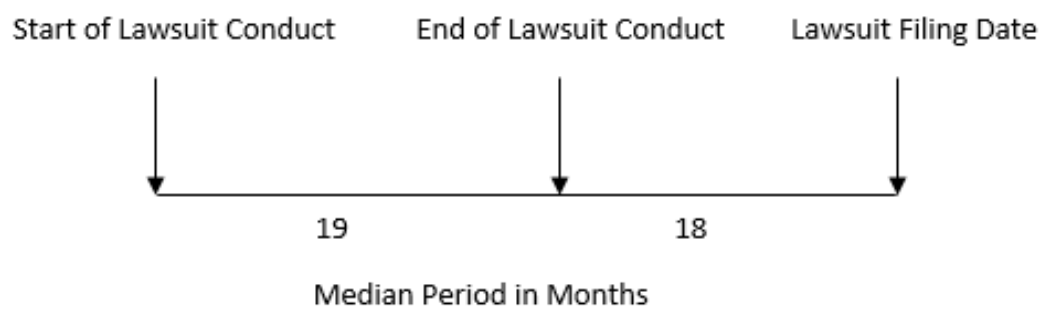




\subsubsection{Lawsuit Conduct}

$L C$ is a variable with a value of one in the financial year that the lawsuit conduct started. The six financial years subsequent to the start of the lawsuit conduct are also given a value of one. The six financial years preceding the start of the lawsuit conduct are given a value of zero. In order for a potential change in accounting conservatism to be reflected in the financial statements, if the start of the lawsuit conduct took place in the last six months of a given financial year, the lawsuit conduct is recorded as having taken place in the following financial year.

\subsubsection{Lawsuit Filing}

$L F$ is a variable with a value of one in the financial year in which the lawsuit filing occurred. The six financial years following the lawsuit filing are also given a value of one. The six financial years preceding the lawsuit filing are given a value of zero. In order for a potential change in accounting conservatism to be reflected in the financial statements, if the lawsuit filing took place in the last six months of a given financial year, the lawsuit filing is recorded as having taken place in the following financial year.

\subsection{Test Methodology}

\subsubsection{Test of Hypotheses One and Two}

Hypothesis one and two theorize that following both the conduct that gives rise to a securities lawsuit, and the filing of a securities lawsuit, 
firms will adopt a higher level of conservatism. Model 2a tests the impact of $L C$ on Cscore. Model 2b tests for the impact of $L F$ on Cscore.

Table 4-3: Model Two

\begin{tabular}{|c|c|}
\hline Model $2 a$ & $\begin{array}{l}\text { Cscore }_{i, t}=b_{0}+b_{1} L C_{i, t}+b_{2} \operatorname{Size}_{i, t}+b_{3} M B_{i, t}+b_{4} \operatorname{Lev}_{i, t}+b_{5} R V_{i, t}+b_{6} C F O_{i, t}+b_{7} S G_{i, t}+ \\
b_{8} R D E_{i, t}+b_{9} R D E \_D U M_{i, t}+\varepsilon_{i, t}\end{array}$ \\
\hline Model $2 b$ & $\begin{array}{l}\text { Cscore }_{i, t}=c_{0}+c_{1} L F_{i, t}+c_{2} \text { Size }_{i, t}+c_{3} M B_{i, t}+c_{4} L e v_{i, t}+c_{5} R V_{i, t}+c_{6} C_{F} O_{i, t}+c_{7} S G_{i, t}+c_{8} R D E_{i, t} \\
+c_{9} R D E_{i} D U M_{i, t}+\varepsilon_{i, t}\end{array}$ \\
\hline
\end{tabular}

Table 4-4: Model Two Variable Definitions

\begin{tabular}{|c|c|}
\hline \multicolumn{2}{|r|}{ Panel A: Dependent Variables } \\
\hline Cscore & $\begin{array}{l}\text { Measures conditional accounting conservatism, following the Khan and Watts (2009) } \\
\text { methodology, as described in section 4.2. }\end{array}$ \\
\hline \multicolumn{2}{|r|}{ Panel B: Independent Variables } \\
\hline$L C$ & As described in section 4.3.1. \\
\hline$L F$ & As described in section 4.3.2. \\
\hline$R V$ & The st andard deviation of the change in revenue over the previous five years. \\
\hline $\mathrm{CFO}$ & Cash flow before extraordinary items, deflated by total assets. \\
\hline$S G$ & The percentage change in sales from ${ }_{t-1}$ to $_{t}$. \\
\hline$R D E$ & $\begin{array}{l}\text { Research and development expense plus advertising divided by the net sales. The } \\
\text { methodology follows Francis et al. (2004) with missing dat given a value of zero. }\end{array}$ \\
\hline$R D E \_D U M$ & Equal to one for firms which report zero $R D E$ and zero otherwise. \\
\hline 24 & r definitions of the remaining variables \\
\hline
\end{tabular}

\subsubsection{Model One Coefficient Sign Predictions}

Drawing on the literature discussed in chapter three, $L C$ is predicted to be positive and provide support for hypothesis one, and $L F$ is predicted to be positive and provide support for hypothesis two.

Size is expected to decrease the demand from investors for accounting conservatism, thus the coefficient on Size is expected to be negative 
(Khan and Watts, 2009; Watts, 2003). Firms with a higher $M B$ are viewed as having more growth options, which are positively correlated with agency costs (Khan and Watts, 2009; Watts, 2003). The agency costs are expected to drive investor demand for accounting conservatis $m$ and therefore, it is expected that the coefficient on $M B$ will be positive (Khan and Watts, 2009; Watts, 2003). Firms with a higher level of leverage are likely to have additional demand from debt holders to adopt accounting conservatism, thus the coefficient on Lev is expected to be positive (Khan and Watts, 2009; Watts, 2003).

$R V$ is a proxy for operating uncertainty, with operating uncertainty predicted to increase conflict between bondholders and shareholders over dividend policy (Ahmed et al. 2002). $R V$ is noted as leading to greater demand for the adoption of accounting conservatism (Ahmed et al. 2002). Thus, the coefficient on $R V$ is predicted to be positive. $C F O$ is a proxy for profitability (Ahmed and Duellman, 2007), which is expected to lead to greater adoption of accounting conservatism (Ahmed et al. 2002). Thus, the coefficient on $C F O$ is expected to be positive. $S G$ can lead to higher inventory and higher accounts receivable, with the increases in these accruals noted in the literature as increasing the adoption of accounting conservatism (Ahmed and Duellman, 2007). Thus, the coefficient on $S G$ is predicted to be positive.

$R D E$ is reported conservatively under GAAP (Ahmed and Duellman, 2007; Khan and Watts, 2009) thus, the coefficient on $R D E$ is predicted to be positive. Table 4-5 presents the predicted signs for the coefficients arising from the application of model $2 \mathrm{a}$ and model $2 \mathrm{~b}$. 
Table 4-5: Model Two Coefficient Sign Predictions

\begin{tabular}{|c|c|c|}
\hline Variable & Model 2a & Model 2b \\
\hline$L C$ & + & $\mathrm{n} / \mathrm{a}$ \\
\hline$L F$ & $\mathrm{n} / \mathrm{a}$ & + \\
\hline Size & - & - \\
\hline$M B$ & + & + \\
\hline Lev & + & + \\
\hline$R V$ & + & + \\
\hline$C F O$ & + & + \\
\hline$S G$ & + & + \\
\hline$R D E$ & + & + \\
\hline$R D E \_D U M$ & $?$ & $?$ \\
\hline \multicolumn{3}{|c|}{$\begin{array}{l}L C \text { is as described in section 4.3.1. } L F \text { is as described in section 4.3.2. Size is the natural log of market } \\
\text { value of equity. } M B \text { is the market-to-book ratio. } L e v \text { is the sum of long-term and short-term debt divided } \\
\text { by market value of equity. } R V \text { is the standard deviation of the change in revenue over the previous five } \\
\text { years. } C F O \text { is cash flow before extraordinary items, deflated by total assets. } S G \text { is the percentage change } \\
\text { in sales from }{ }_{t-1} \text { to }{ }_{t} . R D E \text { is research and development expense plus advertising divided by the net sales. } \\
\text { The methodology follows Francis et al. (2004) with missing data given a value of zero. } R D E_{-} D U M \text { is equal } \\
\text { to one for firms which report zero } R D E \text { and zero otherwise. }\end{array}$} \\
\hline
\end{tabular}

\subsubsection{Test of Hypotheses Three and Four}

Hypotheses three and four theorize that corporate governance moderates the relationship between securities lawsuits and an increase in accounting conservatism, arising from both the conduct giving rise to a securities lawsuit and the securities lawsuit being filed. Model 3a tests for a moderating influence between audit fees $(A F)$, board size $(B S)$, board meetings $(B M)$, and the percentage of outsider directors $(O D)$ on an association between $L C$ and Cscore. Model $3 \mathrm{~b}$ is run on the governance financial sample and tests for a moderating influence between $A F, B S$, $B M$, and $O D$ on an association between $L F$ and Cscore. 


\section{Table 4-6: Model Three}

\begin{tabular}{|c|c|}
\hline Model $3 a$ & $\begin{array}{l}\text { Cscore }_{i, t}=d_{0}+d_{1} L C_{i, t}+d_{2} \text { Size }_{i, t}+d_{3} M B_{i, t}+d_{4} L \text { v v }_{i, t}+d_{5} R V_{i, t}+d_{6} C F O_{i, t}+d_{7} S_{i, t}+ \\
d_{8} R D E_{i, t}+d_{9} R D E \_D U M_{i, t}+d_{10} A F_{i, t}+d_{11} B S_{i, t}+d_{12} B M_{i, t}+d_{13} O D_{i, t}+d_{14} L C \_A F_{i, t}+ \\
d_{15} L C \_B S_{i, t}+d_{16} L C \_B M+d_{17} L C \_O D_{i, t}+\varepsilon_{i, t}\end{array}$ \\
\hline Model $3 b$ & $\begin{array}{l}\text { Cscore }_{i, t}=e_{0}+e_{1} L F_{i, t}+e_{2} \operatorname{Size}_{i, t}+e_{3} M B_{i, t}+e_{4} L e v_{i, t}+e_{5} R V_{i, t}+e_{6} C F O_{i, t}+e_{7} S G_{i, t}+e_{8} R D E_{i, t} \\
+e_{9} R D E_{-} D U M_{i, t}+e_{10} A F_{i, t}+e_{11} B S_{i, t}+e_{12} B M_{i, t}+e_{13} O D_{i, t}+e_{14} L F \_A F_{i, t}+e_{15} L F \_B S_{i, t}+ \\
e_{16} L F \_B M+e_{17} L F \_O D_{i, t}+\varepsilon_{i, t}\end{array}$ \\
\hline
\end{tabular}

Table 4-7: Model Three Variable Definitions

\begin{tabular}{|l|l|}
\hline \multicolumn{2}{|c|}{ Inde pendent Variables } \\
\hline$A F$ & Total amount of audit fees deflated by total assets. \\
\hline$B S$ & Total number of directors on the board. \\
\hline$B M$ & $\begin{array}{l}\text { The number of out side directors on the board divided by the total number of } \\
\text { directors on the board. }\end{array}$ \\
\hline$O D$ & LC interacted with $A F$. \\
\hline$L C \_A F$ & $L C$ interacted with $B S$. \\
\hline$L C \_B S$ & $L C$ interacted with $B M$. \\
\hline$L C \_B M$ & $L C$ interacted with $O D$. \\
\hline$L C \_O D$ & $L F$ interacted with $A F$. \\
\hline$L F \_A F$ & $L F$ interacted with $B S$. \\
\hline$L F \_B S$ & $L F$ interacted with $B M$. \\
\hline$L F \_B M$ & $L F$ interacted with $O D$. \\
\hline$L F \_O D$ & \\
\hline See Table 4-2 and $4-4$ for definitions of the remaining variables. \\
\hline
\end{tabular}

\subsubsection{Model Three Coefficient Sign Predictions}

Drawing on the literature in chapter three, the coefficients on the interacted corporate governance lawsuit variables are predicted, in line with hypotheses three and four, to be statistically significant. However, the existing literature has not considered how corporate governance may moderate the level of accounting conservatism change following conduct 
which gives rise to a securities lawsuit, and the filing of a securities lawsuit. As such, no sign prediction can be offered for the coefficients on the interacted corporate governance lawsuit variables.

Drawing on the literature in chapter three, lower $A F$ is linked to a higher level of accounting conservatism (DeFond et al. 2015; Lee et al. 2014). As such, audit fees are predicted to be negatively correlated with the level of accounting conservatism. No literature has previously found a direct link between $B S$ and the level of accounting conservatism or a direct link between $B M$ and the level of accounting conservatism. In particular, Ahmed and Duellman (2007) found that $B S$ and $B M$ are not a significant predictor of conservatism. However, Lara et al. (2009) did find that when $B S$ and $B M$ are included in a composite variable, which includes an external governance variable, the composite variable is positively linked to the adoption of higher levels of accounting conservatism. As such, no sign predictions are offered for the coefficients on $B S$ and $B M$. The literature links increased board independence to higher levels of accounting conservatism (Ahmed and Duellman, 2007). As such, the coefficient on $O D$ is predicted to be positive. 


\subsection{Study Period and Sample Selection}

The study examines securities lawsuits which were filed from January 2002 to December 2010. To recognise firm conduct prior to the filing date and firm response to the filing, the lawsuit variables cover the period 1999 to 2012. This study period was selected for two reasons. Firstly, the study period takes place over a range of different business cycles ${ }^{1}$. Secondly, all of the securities lawsuits occur under the same regulatory framework. The study employs three types of variables; securities lawsuits, financial, and governance. Information on lawsuits was hand collected from the Stanford Securities Class Action Clearinghouse. Data on the financial variables was available from the Compustat and CRSP databases and for the governance variables from the Corporate Governance Library database.

\subsubsection{Securities Lawsuits}

For the period 2002 to $2010,2,114$ private securities lawsuits taken under SEC rule 10b-5 were identified in the Stanford Securities Class Action Clearinghouse. The information collected included: a description of the alleged conduct, the year and month the lawsuit conduct finished, and the lawsuit filing year and month.

In order to ensure a homogeneous disclosure lawsuit sample, each lawsuit was reviewed and lawsuits that concerned a debt listing, an IPO allocation, or otherwise were not related to past firm disclosure, were

\footnotetext{
${ }^{1}$ Specifically, the Dotcom bubble is documented as occurring during the period 1998 to 2000 and is followed by the subsequent Dotcom crash during the period 2000 to 2002 (Wollscheid, 2012). Additionally, the Global Financial Crisis is documented as occurring during the period 2007-2009 (Mishkin, 2011).
} 
removed from the sample. This resulted in the deletion of lawsuits alleging insider trading, and improper financial transactions, as these lawsuits may influence firm behaviour differently from disclosurerelated lawsuits. This left a total of 1,379 lawsuits still in the sample. In order to clearly identify pre and post lawsuit periods, firms subject to more than one securities lawsuit during the study period were also deleted from the sample. This resulted in a loss of 128 lawsuits, leaving a total of 1,251 lawsuits in the sample.

A further 634 lawsuits were also deleted as the corresponding firm was either not listed on the National Association of Securities Dealers Automated Quotations (NASDAX) or New York Stock Exchange (NYSE) and thus not included in the Compustat and CRSP databases, or had missing data in the Compustat and CRSP databases. This left 617 lawsuits but in four cases the conduct years fell outside the period 1999 -2012 and thus the number of conduct lawsuits reduced to 613. Each lawsuit observation had at least one pre-lawsuit observation from the same firm. Selection of the lawsuit sample is summarized in Table 4-9 and Table 4-10 presents the number of $L C$ and $L F$ by year.

Table 4-9: Lawsuit Sample Selection

\begin{tabular}{lc}
\hline Total lawsuits & 2,114 \\
Less lawsuits related to a debt listing, IPO, or otherwise not related to & $(735)$ \\
disclosure & $(128)$ \\
Less lawsuits related to the same firm & \\
Less lawsuits for unlisted firms or with missing datain the financial & $(634)$ \\
databases & 617 \\
\hline Lawsuit filing sample & $(4)$ \\
\hline Less lawsuits with no conduct year & 613 \\
\hline Lawsuit conduct sample
\end{tabular}


Table 4-10: Lawsuits by Financial Year

\begin{tabular}{lcc}
\hline Financial Year & Conduct & Filing \\
\hline 1999 & 37 & 0 \\
2000 & 35 & 0 \\
2001 & 71 & 0 \\
2002 & 54 & 80 \\
2003 & 101 & 78 \\
2004 & 57 & 91 \\
2005 & 52 & 80 \\
2006 & 42 & 48 \\
2007 & 77 & 67 \\
2008 & 36 & 60 \\
2009 & 35 & 56 \\
2010 & 16 & 57 \\
\hline Total & 613 & 617 \\
\hline
\end{tabular}

Given the construction of the lawsuit variables $L C$ and $L F$, Table 4-11 presents the number of observations on the variables by financial year. The variable $L C$ is constructed with a total of 2,528 observations coded as one and 2,048 observations coded as zero for a total of 4,576 firmyear observations. Similarly, the $L F$ variable has a total of 2,299 observations coded as one, and 2,416 observations coded as zero for a total of 4,715 firm-year observations. Table 4-11 presents the number of $L C$ and $L F$ observations by financial year. 
Table 4-11: Constructed Lawsuit Observations

\begin{tabular}{lcc}
\hline FinancialYear & $L C$ & $L F$ \\
\hline 1999 & 261 & 198 \\
2000 & 303 & 246 \\
2001 & 365 & 313 \\
2002 & 391 & 340 \\
2003 & 418 & 389 \\
2004 & 428 & 420 \\
2005 & 422 & 423 \\
2006 & 402 & 414 \\
2007 & 371 & 406 \\
2008 & 321 & 392 \\
2009 & 288 & 378 \\
2010 & 250 & 335 \\
2011 & 202 & 265 \\
2012 & 154 & 196 \\
\hline Total & 4,576 & 4,715 \\
\hline
\end{tabular}

\subsubsection{Financial Variables}

Data on the financial variables was extracted from the Compustat and CRSP databases. The sample consisted of 96,038 firm-year observations on 13,356 US firms listed on either NYSE or the NASDAQ between the financial years 1998 to 2012 .

Following the approach to data preparation used by Basu $(1997 ; 1995)$ the lagged market value of equity was used as a deflator for earnings $(X)$. The financial year 1998 was then removed from the financial sample, which resulted in a loss of 8,175 firm observations, leaving 87,863 firmyear observations on 12,203 firms. Firms with missing data on the variables returns $(R)$, earnings $(X)$, lagged market value of equity, and those with a price per share of less than $\$ 1$ or negative equity were removed from the sample. This resulted in a loss of 26,493 firm-year 
observations, leaving an initial financial sample comprised of 61,370 firm-year observations on 9,475 firms. Selection of the initial financial sample is summarized in Table 4-12 Panel A.

Following the approach to data preparation used by Khan and Watts (2009), firm-years with missing data for Size, MB and Lev were removed from the financial sample. This resulted in a loss of 2,081 firm-years, leaving a final financial sample consisting of 9,350 firms and 59,289 firm-years. Firm-years in the top and bottom $1 \%$ of Size, MB, Lev and the market value of equity were winsorized. This is in contrast to previous studies (Ball et al. 2000; Khan and Watts, 2009) which instead delete firm-years in the top and bottom $1 \%$ of Size, MB, Lev and the market value of equity. The final financial sample is summarised in Table 4-12, Panel B.

\subsubsection{Governance Variables}

Data on the governance variables was obtained from the Corporate Governance Library database. Unfortunately the data was available only from 2001 to 2012 and thus the study period was reduced from fourteen years to twelve years for the tests of corporate governance.

A total of 27,205 firm-year observations on 4,926 firms were collected. Firms with missing data for $B S, A F, B M$ and $O D$ were removed from the sample. The corporate governance firm-year observations were matched with the final financial sample of firm-year observations, reducing the final financial sample by 42,682 firm-years down to a total of 16,607 firm-year observations on 3,402 firms. Selection of the governance sample is summarized in Table 4-12, Panel B. 


\section{Table 4-12: Financial Sample Selection}

\begin{tabular}{ll}
\hline Selecting Criteria & Panel A: Initial Financial Sample Selection \\
\hline & Number of Observations \\
Total firm-year observations on 13,356 firms listed on the NYSE and NASDAQ bet ween 1998 and 2012 and retrieved from \\
COMPUST AT and CRSP.
\end{tabular}




\subsection{Robustness}

\subsubsection{Prior Year Accounting Conservatism}

Khan and Watts (2009) wrote that the current firm-year level of accounting conservatism is correlated to the prior firm-year level of accounting conservatism. Therefore, to ensure the tests of hypotheses one and two are robust to the prior year level of accounting conservatis m, this study estimates models $4 \mathrm{a}$ and $4 \mathrm{~b}$ as specified in Table 4-13.

Table 4-13: Model Four

\begin{tabular}{|l|l|}
\hline Model 4a & $\begin{array}{l}\text { Cscore }_{i, t}=f_{0}+f_{l} \text { Cscore }_{(\mathrm{t}-1)}+f_{2} L_{i, t}+f_{3} \text { Size }_{i, t}+f_{4} M_{i, t}+f_{5} \text { Lev }_{i, t}+f_{6} R V_{i, t}+f_{7} \text { CFO }_{i, t}+f_{8} S G_{i, t} \\
+f_{9} R D E_{i, t}+f_{10} R D E_{-} D U M_{i, t}+\varepsilon_{i, t}\end{array}$ \\
\hline Model $4 b$ & $\begin{array}{l}\text { Cscore }_{i, t}=g_{0}+g_{1} \text { Cscore }_{(\mathrm{t}-1)}+g_{2} L F_{i, t}+g_{3} \text { Size }_{i, t}+g_{4} M B_{i, t}+g_{5} \text { Lev }_{i, t}+g_{6} R V_{i, t}+g_{7} \text { CFO }_{i, t}+ \\
g_{8} S_{i, t}+g_{9} R D E_{i, t}+g_{10} R D E_{-} D U M_{i, t}+\varepsilon_{i, t}\end{array}$ \\
\hline
\end{tabular}

Table 4-14: Model Four Variable Definitions

\begin{tabular}{|l|l|}
\hline \multicolumn{2}{|c|}{ Independent Variables } \\
\hline Cscore $(t-1)^{2}$ & Firm-year conservatism (Cscore) lagged by one year. \\
\hline See Table 4-2 and 4-4 for definitions of the remaining variables. \\
\hline
\end{tabular}

\subsubsection{Alternative Measures of Securities Lawsuits}

Conclusions drawn from the tests based on the variables $L C$ and $L F$ do not provide an indication of the strength of the initial reaction to the lawsuit conduct and filing. Furthermore, the results may reflect survivor bias. Two additional measures of securities lawsuits, $L C S$ and $L F S$, were thus constructed and used to test the robustness of the results. 
$L C S$ is equal to one in the financial year the lawsuit conduct started. For the three financial years following the start of the conduct, LCS is also equal to one. The three financial years preceding the start of the lawsuit conduct are given a value of zero. In order for a potential change in accounting conservatism to be reflected in the financial statements, if the lawsuit conduct started in the last six months of the firm's financial year, the lawsuit conduct is recorded as taking place in the following financial year. The variable LCS has a total of 1,796 observations coded as one and 1,379 observations coded as zero, for a total of 3,175 firm-year lawsuit observations. Table 4-15 presents the number of LCS observations by year.

$L F S$ is a variable with a value of 1 in the financial year in which the lawsuit filing occurred. The subsequent three financial years following the lawsuit filing are given a value of one. The three financial years preceding the lawsuit filing are given a value of zero. In order for a potential change in accounting conservatism to be reflected in the financial statements, where the lawsuit filing occurred in the last six months of the firm's financial year, the lawsuit filing is recorded as taking place in the following financial year. The variable $L F S$ has a total of 1,714 observations coded as one and 1,511 observations coded as zero, for a total of 3,225 firm-year lawsuit observations. Table 4-15 presents the number of $L F S$ observations by year. 
Table 4-15: Constructed Lawsuit Observations

\begin{tabular}{lcc}
\hline FinancialYear & $L C S$ & $L F S$ \\
\hline 1999 & 130 & 31 \\
2000 & 191 & 98 \\
2001 & 272 & 191 \\
2002 & 307 & 243 \\
2003 & 335 & 291 \\
2004 & 349 & 334 \\
2005 & 337 & 351 \\
2006 & 297 & 348 \\
2007 & 268 & 332 \\
2008 & 216 & 280 \\
2009 & 181 & 248 \\
2010 & 150 & 214 \\
2011 & 94 & 157 \\
2012 & 48 & 107 \\
\hline Total & 3,175 & 3,225 \\
\hline
\end{tabular}

The robustness tests involve estimation of Models 2aa, 2bb, 3aa, 3bb, $4 \mathrm{aa}$, and $4 \mathrm{bb}$ as specified in $4-16$.

Table 4-16: Lawsuit Measurement Models and Definitions

\begin{tabular}{|c|c|}
\hline \multicolumn{2}{|r|}{ Panel A: Alternative Lawsuit Models } \\
\hline Model $2 a a$ & $\begin{array}{l}\text { Cscore }_{i, t}=h_{0}+h_{1} L C S_{i, t}+h_{2} \text { Size }_{i, t}+h_{3} M B_{i, t}+h_{4} \operatorname{Lev}_{i, t}+h_{5} R V_{i, t}+h_{6} C F O_{i, t}+h_{7} S_{i, t}+ \\
h_{8} R D E_{i, t}+h_{9} R D E \_D U M_{i, t}+\varepsilon_{i, t}\end{array}$ \\
\hline Model $2 b b$ & $\begin{array}{l}\text { Cscore }_{i, t}=i_{0}+i_{1} L_{F S} S_{i, t}+i_{2} \text { Size }_{i, t}+i_{3} M_{i, t}+i_{4} \text { Lev }_{i, t}+i_{5} R V_{i, t}+i_{6} C F O_{i, t}+i_{7} S G_{i, t}+i_{8} R D E_{i, t}+ \\
i_{9} R D E_{-} D U M_{i, t}+\varepsilon_{i, t}\end{array}$ \\
\hline Model $3 a a$ & $\begin{array}{l}\text { Cscore }_{i, t}=j_{0}+j_{1} L F S_{i, t}+j_{2} \text { Size }_{i, t}+j_{3} M B_{i, t}+j_{4} L e v_{i, t}+j_{5} R V_{i, t}+j_{6} C F O_{i, t}+j_{7} S G_{i, t}+j_{8} R D E_{i, t}+ \\
j_{9} R D E_{-} D U M_{i, t}+j_{10} A F_{i, t}+j_{11} B S_{i, t}+j_{12} B M_{i, t}+j_{13} O D_{i, t}+j_{14} L F S_{-} O D_{i, t}+j_{15} L F S_{-} B S_{i, t}+ \\
j_{16} L F S_{-} A F+j_{17} L F S \_B M_{i, t}+\varepsilon_{i, t}\end{array}$ \\
\hline Model $3 b b$ & $\begin{array}{l}\text { Cscore }_{i, t}=k_{0}+k_{1} L C S_{i, t}+k_{2} \operatorname{Size}_{i, t}+k_{3} M B_{i, t}+k_{4} L e v_{i, t}+k_{5} R V_{i, t}+k_{6} C F O_{i, t}+k_{7} S G_{i, t}+ \\
k_{8} R D E_{i, t}+k_{9} R D E_{-} D U M_{i, t}+k_{10} A F_{i, t}+k_{11} B S_{i, t}+k_{12} B M_{i, t}+k_{13} O D_{i, t}+k_{14} L C S_{-} O D_{i, t}+ \\
k_{15} L C S \_B S_{i, t}+k_{16} L C S \_A F+k_{17} L C S \_B M_{i, t}+\varepsilon_{i, t}\end{array}$ \\
\hline Model $4 a a$ & $\begin{array}{l}\text { Cscore }_{i, t}=l_{0}+l_{l} \text { Cscore }_{(\mathrm{t}-1)}+l_{2} L C_{i, t}+l_{3} \text { Size }_{i, t}+l_{4} M B_{i, t}+l_{5} \text { Lev }_{i, t}+l_{6} R V_{i, t}+l_{7} C_{F} O_{i, t}+l_{8} S G_{i, t} \\
+l_{9} R D E_{i, t}+l_{10} R D E_{-} D U M_{i, t}+\varepsilon_{i, t}\end{array}$ \\
\hline Model $4 b b$ & $\begin{array}{l}\text { Cscore }_{i, t}=m_{0}+m_{1} \operatorname{Cscore}_{(\mathrm{t}-1)}+m_{2} L F_{i, t}+m_{3} \text { Size }_{i, t}+m_{4} M B_{i, t}+m_{5} L e v_{i, t}+m_{6} R V_{i, t}+m_{7} C F O_{i, t} \\
+m_{8} S_{i, t}+m_{9} R D E_{i, t}+m_{10} R D E_{-} D U M_{i, t}+\varepsilon_{i, t}\end{array}$ \\
\hline
\end{tabular}




\begin{tabular}{|l|l|}
\hline \multicolumn{2}{|c|}{ Panel B: Alternative Lawsuit Variable Definitions } \\
\hline$L C S$ & As described in section 4.6.2. \\
\hline LFS & As described in section 4.6.2. \\
\hline See Table 4-2, 4-4,4-7, 4-14 for definitions of the remaining dependent and independent variables. \\
\hline
\end{tabular}

\subsubsection{Alternative Measure of Conservatism}

The Basu (1997; 1995) earnings measure of accounting conservatism is used as an alternative measure of accounting conservatism. The Basu (1997) earnings measure of accounting conservatism measures the timeliness with which bad news is reflected into firm earnings (Basu 1997; 1995). When firms incorporate bad news into their earnings faster than good news the coefficient on $R$ will be lower than the coefficient on $R \_D$, indicating accounting conservatism.

The Basu (1997) regression model has been adopted and modified in other studies (Ahmed and Duellman, 2007; Jenkins and Velury, 2008; LaFond and Watts, 2008) to include additional interaction variables that capture the influence of firm governance, firm financial characteristics, and external events, on accounting conservatism. This study follows this approach, by including in the Basu (1997) regression lawsuit variables which are interacted with $R$ and $R \_D$, as specified in model 5 in Table 417.

The Basu (1997) measure of conservatism is used as an alternative measure rather than the prime measure as it does not recognize crosssectional variation in the adoption of accounting conservatism and fails to detect changes affecting firm conservatism that are both time and firm specific (Khan and Watts, 2009). 
Table 4-17: Model Five

\begin{tabular}{|l|l|}
\hline Model 5a & $X_{i, t}=n_{0}+n_{1} R_{i, t}+n_{2} D_{i, t}+n_{3} R \_D_{i, t}+n_{4} L C_{i, t}+n_{5} L C_{-} R_{i, t}+n_{6} L C_{-} D_{i, t}+n_{7} L C_{-} R \_D_{i, t}+\varepsilon_{i, t}$ \\
\hline Model 5b & $X_{i, t}=o_{0}+o_{1} R_{i, t}+o_{2} D_{i, t}+o_{3} R \_D_{i, t}+o_{4} L F_{i, t}+o_{5} L F \_R_{i, t}+o_{6} L F \_D_{i, t}+o_{7} L F \_R \_D_{i, t}+\varepsilon_{i, t}$ \\
\hline Model 5c & $X_{i, t}=p_{0}+p_{1} R_{i, t}+p_{2} D_{i, t}+p_{3} R \_D_{i, t}+p_{4} L F S_{i, t}+p_{5} L F S \_R_{i, t}+p_{6} L F S_{-} D_{i, t} p 7 L F \_R \_D_{i, t}+\varepsilon_{i, t}$ \\
\hline Model $5 d$ & $X_{i, t}=q_{0}+q_{1} R_{i, t}+q_{2} D_{i, t}+q_{3} R \_D_{i, t}+q_{4} L C S_{i, t}+q_{5} L C S \_R_{i, t}+q_{6} L C S \_D_{i, t}+q_{7} L C S \_R \_D_{i, t}+$ \\
& $\varepsilon_{i, t}$ \\
\hline
\end{tabular}

Table 4-18: Model Five Variable Definitions

\begin{tabular}{|l|l|}
\hline \multicolumn{2}{|c|}{ Independent Variables } \\
\hline$L C \_R$ & $L C$ interacted with $R$. \\
\hline$L C \_D$ & $L C$ interacted with $D$. \\
\hline$L C \_R \_D$ & $L C$ interacted with $R$ and interacted with $D$. \\
\hline$L F \_R$ & $L F$ interacted with $R$. \\
\hline$L F \_D$ & $L F$ interacted with $D$. \\
\hline$L F \_R \_D$ & $L F$ interacted with $R$ and interacted with $D$. \\
\hline$L C S \_R$ & $L C S$ interacted with $R$. \\
\hline$L C S \_D$ & $L C S$ interacted with $D$. \\
\hline$L C S \_R \_D$ & $L C S$ interacted with $R$ and interacted with $D$. \\
\hline$L F S \_R$ & $L F S$ interacted with $R$. \\
\hline$L F S \_D$ & $L F S$ interacted with $D$. \\
\hline$L F S \_R \_D$ & $L F S$ interacted with $R$ and interacted with $D$. \\
\hline See Table 4.2 for definitions of the remaining variables. \\
\hline
\end{tabular}

\subsubsection{Self Selection Bias}

The Heckman two-stage procedure is employed to control for any potential self-selection bias that may arise due to unobservable firm and manager characteristics (Tucker, 2010). Model 2a, 2b, 3a, and 3b are reestimated in a two-stage regression where the inverse Mills ratio (IMR) estimated from the first stage is included in the second stage. 


\subsubsection{Univariate Testing}

A t-test is conducted to compare the mean Cscore in the pre-lawsuit and post-lawsuit years for the variables LC, LF, LCS and LFS.

\subsection{Chapter Summary}

This chapter describes the specifications of the variables, the test methodology for hypotheses one to four, the study period and sample, and robustness testing.

Securities lawsuits are measured from both the start date of the lawsuit conduct and the lawsuit filing date. This enables the study to examine firm response to engaging in the conduct that gives rise to the securities lawsuit and the actual filing of the lawsuit.

The methodology employed to test hypotheses one and two examines the link between the conduct which gives rise to the securities lawsuit, the filing of securities lawsuits, and the firm adoption of accounting conservatism. The methodology employed to test hypotheses three and four examines the moderating influence of corporate governance on the link between the conduct which gives rise to a securities lawsuit, the filing of the lawsuit, and firm adoption of accounting conservatism.

The sample of lawsuits were filed during the period 2002 to 2010 and comprise 613 conduct lawsuits, and 617 filing lawsuits. Accounting conservatism is measured by the Khan and Watts (2009) measure. For the study period 1999 to 2012, the initial financial sample is comprised of 9,475 firms and 61,370 firm-years. The final financial sample that 
excludes firms with missing data for market-to-book, size and leverage comprises a total of 9,350 firms and 59,289 firm-years. The governance sample which excludes all firm-years with missing governance data comprises 3,402 firms and 16,607 firm-years.

The robustness tests include the use of alternative lawsuit variables, lagged conservatism, and the Basu (1997) measure of accounting conservatism. Chapter six reports on the tests of the hypotheses. 


\section{CHAPTER FIVE: RESULTS AND INTERPRETATION}

\subsection{Chapter Introduction}

This chapter presents the results of the empirical tests of the hypotheses using the methodology described in chapter four. It also interprets the results and draws on the literature review and the theoretical framework presented in chapter three.

Section 5.2 provides summary statistics for the financial sample and the governance sample. Section 5.3 applies the Khan and Watts (2009) twostage methodology to estimate the firm-year Cscore and firm-year Gscore. Section 5.4 presents the Pearson and Spearman measures of association for the financial and governance variables using the governance sample. Section 5.5 presents the results from estimations of models 2 and 3. Section 5.6 presents the results of the robustness tests of model 2 and 3. Section 5.7 provides a discussion of the key findings and section 5.8 provides the chapter summary.

\subsection{Descriptive Statistics}

Table 5.1 presents the summary statistics for the initial financial sample, the final financial sample and the governance sample. Panel A provides the summary statistics for earnings and returns for the initial financial sample. Panel B presents the summary statistics for size, the ratio of market-to-book, leverage, sales growth, revenue volatility and cash flow for the final financial sample. Panel $\mathrm{C}$ presents the summary statistics for board size, audit fees, board meetings, and the percentage of outside 
directors for the governance sample. With the exception of model 1, which uses the full final financial sample, each model uses a subset of firm-years from either the initial financial sample, or the final financial sample, or the governance sample. As such, the descriptive statistics presented in Table 5-1 may vary for each model.

Table 5-1: Descriptive Statistics

\begin{tabular}{|c|c|c|c|c|c|}
\hline & Mean & $\begin{array}{l}\text { Standard } \\
\text { Deviation }\end{array}$ & Q1 & Median & Q3 \\
\hline \multicolumn{6}{|c|}{ Panel A: Initial Financial Sample (1999-2012) of 61,370 firm-year observations } \\
\hline$X$ & -0.007 & 0.270 & -0.021 & 0.045 & 0.079 \\
\hline$R$ & 0.012 & 0.606 & -0.248 & 0.060 & 0.321 \\
\hline \multicolumn{6}{|c|}{ Panel B: Final Financial Sample (1999-2012) of 59,289 firm-year observations } \\
\hline Size & 5.792 & 2.022 & 4.294 & 5.715 & 7.154 \\
\hline$M B$ & 3.700 & 14.714 & 1.137 & 1.822 & 3.117 \\
\hline Lev & 0.522 & 0.259 & 0.309 & 0.519 & 0.731 \\
\hline$R V$ & 0.422 & 0.381 & 0.188 & 0.321 & 0.759 \\
\hline CFO & -0.022 & 0.269 & -0.018 & 0.025 & 0.067 \\
\hline$S G$ & 0.605 & 0.405 & 0.813 & 0.998 & 1.32 \\
\hline$R D E$ & 0.317 & 0.964 & 0.000 & 0.000 & 0.099 \\
\hline$R D E \_D U M$ & 0.422 & 0.477 & 0.000 & 1.000 & 1.000 \\
\hline \multicolumn{6}{|c|}{ Panel C: Governance Sample (2002-2012) of 16,607 firm-year observations } \\
\hline$A F$ & 1.984 & 27.854 & 0.327 & 0.850 & 1.548 \\
\hline$B S$ & 9.072 & 2.594 & 7.000 & 9.000 & 11.000 \\
\hline$B M$ & 8.138 & 3.910 & 6.000 & 7.000 & 10.000 \\
\hline$O D$ & 0.815 & 0.167 & 0.760 & 0.850 & 0.880 \\
\hline OutsideDir & 6.305 & 2.509 & 5.000 & 6.000 & 8.000 \\
\hline
\end{tabular}

$X$ is net income before extraordinary items, scaled by lagged market value of equity. $R$ is the firm's monthly compounded returns, starting 4 months after fiscal yearend and accumulating over 12 months, following the Basu (1995; 1997) methodology. Size is the natural log of market value of equity. $M B$ is the market-to-book ratio. Lev is the sum of long-term and short-term debt divided by market value of equity. $R V$ is the standard deviation of the change in revenue over the previous five years. CFO is cash flow before extraordinary items, deflated by total assets. $S G$ is the percentage change in sales from $\mathrm{t}_{\mathrm{t}-1}$ to ${ }_{\mathrm{t}} R D E$ is research and development expense plus advertising divided by the net sales. The methodology follows Francis et al. (2004) with missing data given a value of zero. RDE_DUM is equal to one for firms which report zero $R D E$ and zero otherwise. OutsideDir is defined as the total amount of out side directors. $A F$ is the total amount of audit fees deflated by total assets. $B S$ is the total number of directors on the board $B M$ is the total number of board meetings. $O D$ is the number of outside directors on the board divided by the total number of directors on the board. 


\subsection{Firm-Year Conservatism Measurement}

The firm-year accounting conservatism measure (Cscore) and firm-year good news timeliness measure (Gscore) are calculated according to the two-step methodology described in section 4.2. Table 5-2 presents the mean coefficients from annual cross-sectional regressions of model 1. The mean coefficients may be different from the Basu (1997) coefficients as they are estimated in annual cross-sectional regressions which include the main effects. Equations One and Two, as specified in section 4.2, are then used to calculate firm-year accounting conservatism (Cscore), and firm-year good news timeliness (Gscore).

Table 5-3 presents the resulting summary statistics and correlation matrix for firm-year accounting conservatism measure (Cscore) and firm-year good news timeliness measure (Gscore). Panel A shows the firm-year accounting conservatism measure (Cscore) has a mean of 0.129 and a median of 0.092. Panel A also shows the firm-year good news timeliness measure has a mean of 0.007 and a median of 0.023 .

Panel B presents the Pearson and Spearman measures of association between the firm-year accounting conservatism measure (Cscore) and the firm-year good news timeliness measure (Gscore), -0.492 and -0.404 respectively. These negative associations are consistent with a predicted higher level of asymmetric timeliness for bad news (Roychowdhury and Watts, 2007; LaFond and Watts, 2008 Khan and Watts, 2009). Mean Cscore is available by financial year in Appendix Two. 
Table 5-2: Model 1 Mean Regression Coefficients

\begin{tabular}{|c|c|c|}
\hline & Mean & $\mathrm{t}$-Statistic \\
\hline$R$ & -0.04 & -1.392 \\
\hline$D$ & -0.073 & -3.887 \\
\hline R_Size & 0.009 & 1.190 \\
\hline$R \_M B$ & -0.003 & -2.865 \\
\hline$R \_L e v$ & 0.290 & 1.081 \\
\hline$R \_D$ & 0.218 & 2.086 \\
\hline$R \_D \_S i z e$ & -0.047 & -2.765 \\
\hline$R \_D \_M B$ & -0.004 & -1.044 \\
\hline$R \_D \_L e v$ & 0.395 & 2.895 \\
\hline Size & 0.012 & 5.067 \\
\hline$M B$ & 0.000 & 0.463 \\
\hline Lev & 0.032 & 0.753 \\
\hline D_Size & 0.009 & 2.694 \\
\hline$D \_M B$ & -0.003 & -1.607 \\
\hline D_Lev & 0.002 & 0.892 \\
\hline Intercept & -0.052 & -3.065 \\
\hline$\overline{R^{2}}$ & \multicolumn{2}{|l|}{0.147} \\
\hline Adjusted $R^{2}$ & \multicolumn{2}{|l|}{0.145} \\
\hline$N$. & \multicolumn{2}{|l|}{59,289} \\
\hline \multicolumn{3}{|c|}{ 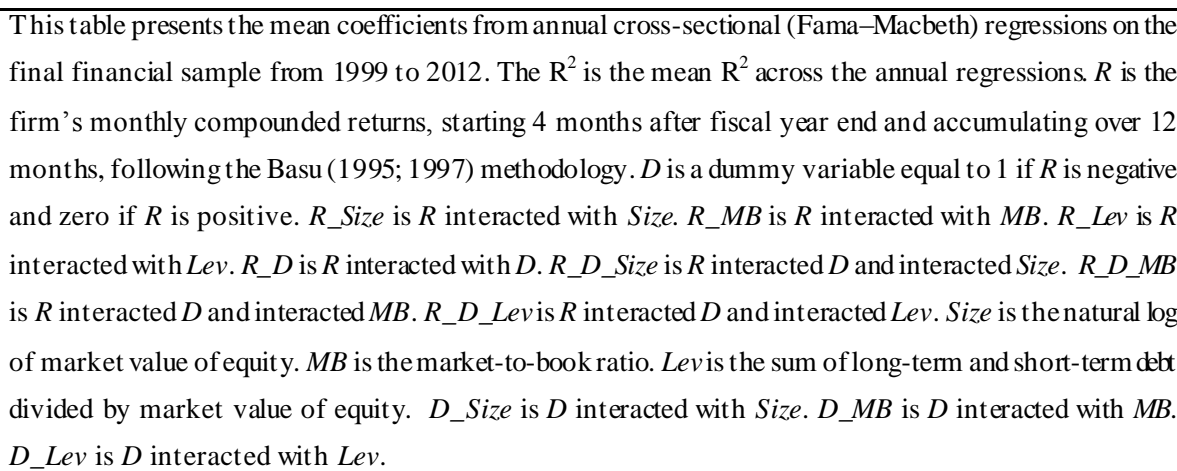 } \\
\hline
\end{tabular}


Table 5-3: Cscore and Gscore

\begin{tabular}{|c|c|c|c|c|c|}
\hline \multicolumn{6}{|c|}{ Panel A: Descriptive Statistics } \\
\hline Panel A & Mean & StdDev & Q1 & Median & Q3 \\
\hline Cscore & 0.301 & 0.246 & 0.190 & 0.260 & 0.350 \\
\hline Gscore & -0.638 & 49.736 & -1.480 & -0.079 & 0.558 \\
\hline \multicolumn{6}{|c|}{ Panel B: Correlation Matrix } \\
\hline & Spearman & $\begin{array}{c}\text { Spearman } \\
\text { p-value }\end{array}$ & Pearson & $\begin{array}{l}\text { Pearson } \\
\text { p-value }\end{array}$ & \\
\hline & $-0.131 * * *$ & 0.000 & $-0.384 * * *$ & 0.000 & \\
\hline$N$. & 59,289 & & & & \\
\hline \multicolumn{6}{|c|}{$\begin{array}{l}\text { Panel A presents the summary statistics and Panel B presents the Pearson and Spearman associations } \\
\text { between Cscore and Gscore. Cscore measures firm-year conditional accounting conservatism, following } \\
\text { the Khan and Watts (2009) methodology, as described in section 4.2. Gscore measures firm-year level of } \\
\text { good news timeliness, following the Khan and Watts (2009) methodology, as described in section 4.2. } \\
* * * \text { denotes (2-Tailed) significance at the } 0.1 \text { level. }\end{array}$} \\
\hline
\end{tabular}

\subsection{Correlation Matrix}

Table 5.4 presents the Pearson and Spearman associations from the governance sample for firm-year accounting conservatism (Cscore), the financial variables, and the governance variables. The correlations are based on the governance sample, as it is the only sample with a complete set of data for all variables used in this study.

Each model uses a subset of firm-years from the initial financial sample, or the final financial sample, or the governance sample. As such, the Pearson and Spearman associations presented in Table 5-4 will vary for each model.

The Pearson and Spearman measures of association between returns and the firm-year accounting conservatism measure (Cscore) are (0.191) and (0.375) respectively and are both significant at the $1 \%$ level. These 
values are in line with the corresponding findings of Khan and Watts (2009).

The Pearson and Spearman measures of association between Lev and the firm-year accounting conservatism measure (Cscore) are 0.044 and (0.001) respectively and are both significant at the $1 \%$ level. This association is consistent with Watts' (2003) theory of contracting demand for accounting conservatism, which argues that in the interests of ameliorating contracting inefficiencies, debt holders will demand the adoption of accounting conservatism. Firms which have higher debt obligations are theorised to be more susceptible to these demands (Khan and Watts 2009; Watts 2003).

The Pearson and Spearman measures of association between Size and the firm-year accounting conservatism measure (Cscore) are (-0.080) and (0.257 ) respectively and are both significant at the $1 \%$ level. The negative association is consistent with Watts' (2003) theory of contracting demand for accounting conservatism, which argues that larger firms are expected to have a lower level of shareholder information asymmetry, leading to reduced shareholder demands for conservative reporting practices (Easley et al. 2002; Watts, 2003).

The Pearson and Spearman measures of association between $M B$ and the firm-year accounting conservatism measure (Cscore) are (-0.234) and (0.095 ) respectively and are both significant at the $1 \%$ level. Literature on the contracting demand for accounting conservatism argues that the ratio of market-to-book can act as a proxy for growth options (Smith and Watts, 1992; Watts 2003). The literature further notes that growth options are associated with contracting efficiencies and accounting 
conservatism demand (Smith and Watts, 1992; Watts 2003). The negative association between $M B$ and the firm-year accounting conservatism measure (Cscore) is therefore not consistent with the literature in this area (Smith and Watts, 1992; Watts 2003). However, the Pearson and Spearman measures of association between $M B$ and Size are (0.059) and (0.376) respectively and are both significant at the $1 \%$ level. As Size is negatively associated with the firm-year accounting conservatism measure (Cscore), a possible explanation could be that the association between $M B$ and firm-year accounting conservatism (Cscore) is influenced by Size rather than firm growth options.

The Pearson and Spearman measures of association between the $R V$ and the firm-year accounting conservatism measure (Cscore) are (-0.028) and (-0.184) respectively and are both significant at the $1 \%$ level. Prior literature theorized that volatility in revenue can cause increased conflict of interest between bond holders and shareholders, leading to the adoption of accounting conservatism (Ahmed et al. 2002; Watts 2003). The negative association between $R V$ and the firm-year accounting conservatism measure (Cscore) is therefore not consistent with the literature. However, the Pearson and Spearman measures of association between $R V$ and Size are (0.378) and (0.716) respectively and are both significant at the $1 \%$ level. As Size is negatively associated with the firmyear accounting conservatism measure (Cscore), a possible explanation could be that the association between revenue volatility and firm-year accounting conservatism (Cscore) is influenced by the size of firms rather than firm growth options.

The Pearson (-0.019) measure of association indicates a negative association between $C F O$ and firm-year accounting conservatism 
(Cscore) at the $10 \%$ level. The Spearman (-0.147) measure of association indicates a negative association between $C F O$ and firm-year accounting conservatism (Cscore) at the $1 \%$ level. The literature argues that cash flow acts as a proxy for firm profitability and is theorized to be positively associated with accounting conservatism (Ahmed et al. 2002). However, the negative measures of association between cash flow and firm-year conservatism (Cscore) are consistent with the empirical findings of Ahmed and Duellman (2007).

The Spearman (-0.036) measure of association indicates a negative association between $S G$ and firm-year accounting conservatism (Cscore) at the $1 \%$ level. This indication is consistent with Ahmed and Duellman (2007) who noted that sales growth can negatively affect market-based measures of accounting conservatism, due to a relation between realised growth and the ratio of market-to-book. No significant Pearson association between $S G$ and Cscore was found.

Prior literature expects a positive association between research and development, marketing expenses, and firm-year accounting conservatism (Ahmed and Duellman, 2012; Watts 2003). No statistically significant Pearson or Spearman association between RDE and Cscore was found.

The Pearson and Spearman measures of association between $B M$ and Cscore are (0.084) and (0.049) respectively and are both significant at the $1 \%$ level. This finding is consistent with the theory presented in the literature, which argues that board meetings are expected to proxy for the monitoring effort of the board, with the monitoring effort of the board 
theorised to positively influence the adoption of accounting conservatis $m$ (Ahmed and Henry, 2011; Klein, 2002; Xie et al. 2003).

The Spearman measure of association finds a negative association between $B S$ (-0.051) and firm-year accounting conservatism (Cscore) at the $1 \%$ level. This association is not consistent with the existing literature, which theorized that board size acts as a proxy for the monitoring effort of the board, and positively influences the adoption of accounting conservatism (Ahmed and Henry, 2011; Klein, 2002; Xie et al. 2003). No significant Pearson association between BS and Cscore was found.

The Spearman measure of association indicates a positive association (0.137) between $A F$ and Cscore at the 1\% level. This finding is consistent with the literature which argued that more expensive audits are associated with an increase in the adoption of accounting conservatism (Lee, Li and Sami, 2015). No significant Pearson association between $A F$ and Cscore was found.

No significant Pearson or Spearman association between $O D$ and Cscore was found. The lack of significant association is inconsistent with Ahmed and Duellman (2007), who found that the percentage of insider directors is associated with accounting conservatism demand.

The correlation results are indicative of bivariate relationships but the hypotheses are ultimately tested in a multivariate context by the regressions reported in section 5.5. 
Table 5-4: Correlations Matrix

\begin{tabular}{|c|c|c|c|c|c|c|c|c|c|c|c|c|c|c|c|c|}
\hline & Cscore & Size & $M B$ & Lev & $R V$ & CFO & $S G$ & $R D E$ & $R D E \_D U M$ & $A F$ & $B S$ & $B M$ & $O D$ & $R$ & $D$ & $X$ \\
\hline Cscore & & $\begin{array}{l}-0.080 * * * \\
(.000)\end{array}$ & $\begin{array}{l}-0.234 * * * \\
(.000)\end{array}$ & $\begin{array}{l}0.044 * * * \\
(.000)\end{array}$ & $\begin{array}{l}-0.028^{* * * *} \\
(.000)\end{array}$ & $*-0.019 *$ & $\begin{array}{l}-0.009 \\
(.180)\end{array}$ & -0.007 & $\begin{array}{l}-0.009 * * \\
(.048)\end{array}$ & $\begin{array}{l}0.004 \\
(.594)\end{array}$ & $\begin{array}{l}-0.022 \\
(.101)\end{array}$ & $\begin{array}{l}0.084 * * * \\
(.005)\end{array}$ & $\left(\begin{array}{l}0.049 \\
(.100)\end{array}\right.$ & $\begin{array}{l}0.191 * * * \\
(.000)\end{array}$ & $=(-0.159 * * * *$ & * $\left(\begin{array}{l}-0.002 \\
(.712)\end{array}\right.$ \\
\hline Size & $\begin{array}{l}-0.257 * * * \\
(.000)\end{array}$ & & $\begin{array}{l}0.059 * * * \\
(.000)\end{array}$ & $\begin{array}{l}0.049 * * * \\
(.000)\end{array}$ & $\begin{array}{l}0.378 * * * \\
(.000)\end{array}$ & $=\begin{array}{l}0.219 * * * \\
(.000)\end{array}$ & $\begin{array}{l}0.004 \\
(.408)\end{array}$ & $\begin{array}{l}0.000 \\
(.957)\end{array}$ & $\begin{array}{l}-0.175^{* * * *} \\
(.000)\end{array}$ & $\begin{array}{l}-0.052 * * * \\
(.000)\end{array}$ & $* \begin{array}{l}0.029 * * * \\
(.000)\end{array}$ & $* \begin{array}{l}0.029 * * * \\
(.000)\end{array}$ & $=\begin{array}{l}0.162 * * * \\
(.000)\end{array}$ & $=\begin{array}{l}0.134 * * * \\
(.000)\end{array}$ & $\mid \begin{array}{l}-0.151^{* * * *} \\
(.000)\end{array}$ & * $\begin{array}{l}0.005 \\
(.254)\end{array}$ \\
\hline$M B$ & $\begin{array}{l}-0.095^{* * *} \\
(.000)\end{array}$ & $\begin{array}{l}0.376 * * * \\
(.000)\end{array}$ & & $\begin{array}{l}0.059 * * * \\
(.000)\end{array}$ & $\left(\begin{array}{l}0.004 \\
(.325)\end{array}\right.$ & $\begin{array}{l}0.047 * * * \\
(.000)\end{array}$ & $\begin{array}{l}0.007 \\
(.872)\end{array}$ & $\begin{array}{l}0.000 \\
(.997)\end{array}$ & $\begin{array}{l}-0.011 \text { *** } \\
(.003)\end{array}$ & $\begin{array}{l}0.007 \\
(.365)\end{array}$ & $\begin{array}{l}-0.016 * * \\
(.039)\end{array}$ & $\begin{array}{l}-0.016 * * \\
(.039)\end{array}$ & -0.008 & $\begin{array}{l}0.053 * * * \\
(.000)\end{array}$ & $=\begin{array}{l}-0.032^{* * * * *} \\
(.000)\end{array}$ & $\begin{array}{l}-0.001 \\
(.724)\end{array}$ \\
\hline Lev & $\begin{array}{l}0.001 * * * \\
(.000)\end{array}$ & $\begin{array}{l}0.107 * * * \\
(.000)\end{array}$ & $\begin{array}{l}0.089 * * * \\
(.000)\end{array}$ & & $\begin{array}{l}0.080 * * * \\
(.000)\end{array}$ & $=\begin{array}{l}0.052 * * * * \\
(.000)\end{array}$ & $\begin{array}{l}0.006 \\
(.873)\end{array}$ & $\begin{array}{l}-0.004 \\
(.366)\end{array}$ & $\begin{array}{l}0.330 * * * \\
(.000)\end{array}$ & $\begin{array}{l}-0.029 * * * \\
(.000)\end{array}$ & $* \begin{array}{l}0.147 * * * \\
(.000)\end{array}$ & $\begin{array}{l}0.146 * * * \\
(.000)\end{array}$ & $=\begin{array}{l}0.188 * * * \\
(.000)\end{array}$ & -0.002 & $\begin{array}{l}-0.038^{* * * *} \\
(.000)\end{array}$ & $\begin{array}{l}-0.000 \\
(.980)\end{array}$ \\
\hline$R V$ & $\begin{array}{l}-0.184 * * * \\
(.000)\end{array}$ & $\begin{array}{l}0.716 * * * \\
(.000)\end{array}$ & $\begin{array}{l}0.028 * * * \\
(.001)\end{array}$ & $=\begin{array}{l}0.200 * * * \\
(.000)\end{array}$ & & $\begin{array}{l}0.043 * * * \\
(.000)\end{array}$ & $\begin{array}{l}0.000 \\
(.958)\end{array}$ & $\begin{array}{l}0.000 \\
(.948)\end{array}$ & $\begin{array}{l}-0.054 * * * * \\
(.000)\end{array}$ & $\begin{array}{l}-0.013 * \\
(.081)\end{array}$ & $\begin{array}{l}0.036 * * * \\
(.000)\end{array}$ & {$\left[\begin{array}{l}0.036 * * * \\
(.000)\end{array}\right.$} & $\begin{array}{l}0.092 * * * \\
.000)\end{array}$ & $\begin{array}{l}0.010 * * \\
(.026)\end{array}$ & $\begin{array}{l}-0.030^{* * * *} \\
(.000)\end{array}$ & $\begin{array}{l}-0.001 \\
(.747)\end{array}$ \\
\hline $\mathrm{CFO}$ & $\begin{array}{l}-0.147 * * * \\
(.000)\end{array}$ & $\begin{array}{l}0.309 * * * \\
(.000)\end{array}$ & $\begin{array}{l}0.492 * * * \\
(.000)\end{array}$ & $=\begin{array}{l}0.437 * * * \\
(.000)\end{array}$ & $\begin{array}{l}0.120 * * * \\
(.000)\end{array}$ & & $\begin{array}{l}0.009 * \\
(.063)\end{array}$ & $\begin{array}{l}0.002 \\
(.644)\end{array}$ & $\begin{array}{l}-0.206 \text { **** } \\
(.000)\end{array}$ & $\begin{array}{l}0.028 * * * \\
(.000)\end{array}$ & $\begin{array}{l}-0.115^{* * *} \\
(.000)\end{array}$ & $* \begin{array}{l}-0.116 * * * \\
(.000)\end{array}$ & $*(-0.001$ & $\begin{array}{l}0.197 * * * \\
(.000)\end{array}$ & $=\begin{array}{l}-0.141^{* * * *} \\
(.000)\end{array}$ & $* \begin{array}{l}0.016 * * * \\
(.000)\end{array}$ \\
\hline$S G$ & $\begin{array}{l}-0.036^{* * *} \\
(.000)\end{array}$ & $\begin{array}{l}0.126 * * * \\
(.000)\end{array}$ & $\begin{array}{l}0.266 * * * \\
(.000)\end{array}$ & $\begin{array}{l}0.127 * * * \\
(.000)\end{array}$ & $\begin{array}{l}0.0017 \\
(.846)\end{array}$ & $\begin{array}{l}0.268 * * * \\
(.000)\end{array}$ & & $\begin{array}{l}0.047 * * * \\
(.000)\end{array}$ & $\begin{array}{l}-0.004 \\
(.366)\end{array}$ & $\begin{array}{l}-0.000 \\
(.959)\end{array}$ & $\begin{array}{l}-0.003 \\
(.683)\end{array}$ & $\begin{array}{l}-0.003 \\
(.683)\end{array}$ & -0.000 & -0.003 & $\begin{array}{l}-0.003 \\
(.458)\end{array}$ & $\begin{array}{l}0.000 \\
(.980)\end{array}$ \\
\hline$R D E$ & $\begin{array}{l}-0.002 \\
(.809)\end{array}$ & $\begin{array}{l}0.070 * * * \\
(.000)\end{array}$ & $\begin{array}{l}0.223 * * * \\
(.000)\end{array}$ & $\begin{array}{l}-0.361 \text { *** } \\
(.000)\end{array}$ & $* \begin{array}{l}0.017 \\
(.048)\end{array}$ & $\begin{array}{l}0.299 * * * \\
(.000)\end{array}$ & $\begin{array}{l}0.103 * * * \\
(.000)\end{array}$ & & $\begin{array}{l}-0.047 \text { **** } \\
(.000)\end{array}$ & $\begin{array}{l}0.001 \\
(.941)\end{array}$ & $\begin{array}{l}-0.001 \\
(.947)\end{array}$ & $\begin{array}{l}-0.004 \\
(.603)\end{array}$ & $\begin{array}{l}-0.003 \\
(.672)\end{array}$ & $\begin{array}{l}-0.003 \\
(.446)\end{array}$ & $\begin{array}{l}0.006 * * * \\
(.159)\end{array}$ & $\begin{array}{l}-0.000 \\
(.990)\end{array}$ \\
\hline$R D E \_D U M$ & $\begin{array}{l}-0.005 \\
(.524)\end{array}$ & $\begin{array}{l}-0.110^{* * * *} \\
(.000)\end{array}$ & $\begin{array}{l}-0.246^{* * * *} \\
(.000)\end{array}$ & $\begin{array}{l}0.33 * * * \\
(.000)\end{array}$ & $\begin{array}{l}-0.035^{* * * *} \\
(.000)\end{array}$ & $* \begin{array}{l}-0.382 * * * \\
(.000)\end{array}$ & $\begin{array}{l}-0.105^{* * * *} \\
(.000)\end{array}$ & $* \begin{array}{l}-0.941 \text { *** } \\
(.000)\end{array}$ & & $\begin{array}{l}0.003 \\
(.682)\end{array}$ & $\begin{array}{l}0.131 * * * \\
(.000)\end{array}$ & * $\begin{array}{l}0.082 * * * \\
(.000)\end{array}$ & $\begin{array}{l}0.014 * \\
(.073)\end{array}$ & $\begin{array}{l}-0.070 * * * \\
(.000)\end{array}$ & $* \begin{array}{l}0.029 * * * \\
(.000)\end{array}$ & $\begin{array}{l}-0.004 \\
(.356)\end{array}$ \\
\hline$A F$ & $\begin{array}{l}0.137 * * * \\
. .000)\end{array}$ & $\begin{array}{l}-0.504 * * * * \\
(.000)\end{array}$ & $\begin{array}{l}0.128 * * * \\
(.000)\end{array}$ & $\mid \begin{array}{l}-0.496 * * * \\
.000)\end{array}$ & $* \begin{array}{l}-0.363 * * * \\
(.000)\end{array}$ & $* \begin{array}{l}0.173 * * * \\
(.000)\end{array}$ & $\begin{array}{l}-0.007 \\
(.393)\end{array}$ & $\begin{array}{l}0.336 * * * \\
(.000)\end{array}$ & $\begin{array}{l}0.292 * * * \\
(.000)\end{array}$ & & $\begin{array}{l}-0.039 * * * \\
(.000)\end{array}$ & $\begin{array}{l}-0.009 \\
(.238)\end{array}$ & $(-0.004$ & $\begin{array}{l}-0.007 \\
(.314)\end{array}$ & $\begin{array}{l}0.006 \\
(.418)\end{array}$ & $\begin{array}{l}-0.013 * \\
(.073)\end{array}$ \\
\hline
\end{tabular}




\begin{tabular}{|c|c|c|c|c|c|c|c|c|c|c|c|c|c|c|c|c|}
\hline$B S$ & $\begin{array}{l}-0.051 \text { **** } \\
(.000)\end{array}$ & $\begin{array}{l}0.412 * * * * \\
(.000)\end{array}$ & $\begin{array}{l}-0.062 * * * * \\
(.000)\end{array}$ & $* \begin{array}{l}0.405 * * * \\
(.000)\end{array}$ & $\begin{array}{l}0.381 * * * \\
(.000)\end{array}$ & $\begin{array}{l}-0.116^{* * * *} \\
(.000)\end{array}$ & $\begin{array}{l}-0.084 * * * \\
(.000)\end{array}$ & $\begin{array}{l}-0.153 * * * \\
(.000)\end{array}$ & $\begin{array}{l}0.120 * * * * \\
(.000)\end{array}$ & $\begin{array}{l}-0.464 * * * * \\
(.000)\end{array}$ & & $\begin{array}{l}0.033 * * * \\
(.000)\end{array}$ & $\begin{array}{l}0.260 * * * \\
(.000)\end{array}$ & $\begin{array}{l}0.007 \\
(.326)\end{array}$ & $\mid \begin{array}{l}-0.044 * * * * \\
(.000)\end{array}$ & $* \begin{array}{l}0.080 * * * \\
(.000)\end{array}$ \\
\hline$B M$ & $\begin{array}{l}0.049 * * * \\
(.000)\end{array}$ & $\begin{array}{l}0.007 \\
(0.442)\end{array}$ & $\begin{array}{l}-0.129 * * * * \\
(.000)\end{array}$ & $* \begin{array}{l}0.200 * * * \\
(.000)\end{array}$ & $\begin{array}{l}0.029 * * * \\
(.001)\end{array}$ & $\begin{array}{l}-0.210^{* * * *} \\
(.000)\end{array}$ & $\begin{array}{l}-0.027 * * * \\
(.002)\end{array}$ & $\mid \begin{array}{l}-0.056 * * * \\
(.000)\end{array}$ & $\begin{array}{l}0.095 * * * \\
(.000)\end{array}$ & $\begin{array}{l}-0.100 * * * \\
(.000)\end{array}$ & $\begin{array}{l}0.091 * * * \\
(.000)\end{array}$ & & $\begin{array}{l}0.102 * * * \\
(.000)\end{array}$ & $=\frac{-0.033^{* * *}}{(.000)}$ & $* \begin{array}{l}0.032 * * * \\
(.000)\end{array}$ & $\begin{array}{l}-0.111 \text { *** } \\
(.000)\end{array}$ \\
\hline$O D$ & $\begin{array}{l}0.063 \\
(.102)\end{array}$ & $\begin{array}{l}0.222 * * * \\
(.000)\end{array}$ & $\begin{array}{l}-0.039 * * * \\
(.000)\end{array}$ & $* \begin{array}{l}0.242 * * * \\
(.000)\end{array}$ & $\begin{array}{l}0.231 * * * \\
(.000)\end{array}$ & $\begin{array}{l}-0.067 \text { *** } \\
(.000)\end{array}$ & $\begin{array}{l}-0.099 * * * \\
(.000)\end{array}$ & $\begin{array}{l}-0.008 \\
(.362)\end{array}$ & $\begin{array}{l}0.011 \\
(.187)\end{array}$ & $\begin{array}{l}-0.172 * * * * \\
(.000)\end{array}$ & $\begin{array}{l}0.408 * * * \\
(.000)\end{array}$ & $\begin{array}{l}0.129 * * * \\
(.000)\end{array}$ & & $\begin{array}{l}0.006 \\
(.390)\end{array}$ & $\begin{array}{l}-0.020 * * * * \\
(.006)\end{array}$ & $* \begin{array}{l}0.009 \\
(.196)\end{array}$ \\
\hline$R$ & $\begin{array}{l}0.375 * * * \\
(.000)\end{array}$ & $\begin{array}{l}0.162 * * * \\
(.000)\end{array}$ & $\begin{array}{l}0.219 * * * \\
(.000)\end{array}$ & $\begin{array}{l}-0.029^{* * * *} \\
(.001)\end{array}$ & $* \begin{array}{l}0.103 * * * \\
(.000)\end{array}$ & $\begin{array}{l}0.110 * * * \\
(.000)\end{array}$ & $\begin{array}{l}-0.027^{* * *} \\
(.000)\end{array}$ & $\begin{array}{l}-0.034 * * * \\
(.001)\end{array}$ & $\begin{array}{l}-0.048 \\
(.107)\end{array}$ & $\begin{array}{l}-0.014 * * * * \\
(.000)\end{array}$ & $\begin{array}{l}0.013 \\
(0.121)\end{array}$ & $\begin{array}{l}-0.033 * * * \\
(.000)\end{array}$ & $\begin{array}{l}0.021 * * * \\
(.012)\end{array}$ & & $\begin{array}{l}-0.703 * * * * \\
(.000)\end{array}$ & $* \begin{array}{l}0.013 * * * * \\
(.001)\end{array}$ \\
\hline$D$ & $\begin{array}{l}-0.291 \text { *** } \\
(.000)\end{array}$ & $\begin{array}{l}-0.19 * * * \\
(.000)\end{array}$ & $\begin{array}{l}-0.187^{* * * *} \\
(.000)\end{array}$ & * $\begin{array}{l}-0.007 \\
(.428)\end{array}$ & $\begin{array}{l}-0.106^{* * * *} \\
(.000)\end{array}$ & $\begin{array}{l}-0.102 * * * \\
(.000)\end{array}$ & $\begin{array}{l}-0.030^{* * *} \\
(.001)\end{array}$ & $\begin{array}{l}-0.016 \\
(.113)\end{array}$ & $\begin{array}{l}0.031 * * * \\
(.000)\end{array}$ & $\begin{array}{l}0.066 * * * \\
(.000)\end{array}$ & $\mid \begin{array}{l}-0.041^{* * * *} \\
(.000)\end{array}$ & $\left\{\begin{array}{l}0.024 * * * \\
(.005)\end{array}\right.$ & $\begin{array}{l}-0.051 \text { **** } \\
(.000)\end{array}$ & $\begin{array}{l}-0.837 * * * \\
(.000)\end{array}$ & & $\begin{array}{l}-0.009 * * * \\
(.016)\end{array}$ \\
\hline$X$ & $\begin{array}{l}0.075^{* * *} * \\
(.000)\end{array}$ & $\begin{array}{l}0.209 * * * \\
(.000)\end{array}$ & $\begin{array}{l}0.000 \\
(.994) \\
\end{array}$ & \begin{tabular}{|l}
$0.104 * * *$ \\
$(.000)$
\end{tabular} & $\begin{array}{l}0.227 * * * \\
(.000)\end{array}$ & $\begin{array}{l}0.482 * * * \\
(.000)\end{array}$ & $\begin{array}{l}0.124 * * * \\
(.000)\end{array}$ & $\begin{array}{l}-0.041 * * * \\
(.000)\end{array}$ & $\begin{array}{l}-0.053 \text { *** } \\
(.000)\end{array}$ & $\begin{array}{l}-0.173^{* * * *} \\
(.000)\end{array}$ & $\begin{array}{l}0.137 * * * \\
(.000)\end{array}$ & $\begin{array}{l}-0.030 * * * \\
(.001)\end{array}$ & $* \begin{array}{l}0.096 * * * \\
(.000)\end{array}$ & $\begin{array}{l}0.290 * * * \\
(.000)\end{array}$ & $\mid \begin{array}{l}-0.269 * * * \\
(.000)\end{array}$ & \\
\hline$N$. & \multicolumn{16}{|l|}{16,607} \\
\hline \multicolumn{17}{|c|}{$\begin{array}{l}\text { This table presents the correlations for the pooled governance sample between } 1999 \text { and } 2012 \text {. The upper (lower) right triangle of the matrix shows Pearson (Spearman) correlations. Cscore } \\
\text { measures firm-year conditional accounting conservatism, following the Khan and Watts (2009) methodology, as described in section } 4.2 . X \text { is net income before extraordinary items, scaled by } \\
\text { lagged market value of equity. } R \text { is the firm's monthly compounded returns, starting } 4 \text { months after fiscal year end and accumulating over } 12 \text { months, following the Basu (1995; } 1997 \text { methodology. } \\
D \text { is a dummy variable equal to } 1 \text { if } R \text { is negative and zero if } R \text { is positive. Size is the natural log of market value of equity. MB is the market-to-book ratio. Lev is the sum of long-term and short- } \\
\text { term debt divided by market value of equity. } R V \text { is the standard deviation of the change in revenue over the previous five years. } C F O \text { is cash flow before extraordinary items, deflated by total } \\
\text { assets. } S G \text { is the percentage change in sales from t-1 to t. } R D E \text { is research and development expenseplus advertising divided by the net sales. Themethodology follows Francis et al. ( } 2004) \text { with } \\
\text { missing data given a value of zero. } R D E \_D U M \text { is equal to one for firms which report zero } R D E \text { and zero otherwise. } A F \text { is the total amount of audit fees deflated by total assets. } B S \text { is the total } \\
\text { number of directors on the board. } B M \text { is the total number of board meetings. } O D \text { is the number of outside directors on the board divided by the total number of directors on the board. *, **, and } \\
* * * \text { denote significance at the } 0.1,0.05 \text { and } 0.01 \text { levels respectively. }\end{array}$} \\
\hline
\end{tabular}




\subsection{Regression Results}

The results from estimating the models used to test the hypotheses are presented in Tables 5-5 to 5-22. Additionally, an initial interpretation of the results is provided. The size of the sample used for the regressions varies according to the relevant intersection of the lawsuit, financial and governance samples.

\subsubsection{Securities Lawsuits and Conservatism (H1 and H2)}

Hypotheses one and two are tested by estimation of model $2 \mathrm{a}$ and $2 \mathrm{~b}$ respectively, as specified in Table 4-3. Model $2 \mathrm{a}$ and model $2 \mathrm{~b}$ are based on the final financial sample and the lawsuit sample. Model $2 a$ and $2 b$ have as the dependent variable, firm-year accounting conservatism (Cscore). The lawsuit variable in model $2 \mathrm{a}$ is $L C$, as described in section 4.3.1. The lawsuit variable in model $2 \mathrm{~b}$ is $L F$, as described in section 4.3.2. Financial variables which have been noted in the literature as impacting on accounting conservatism are included as controls (Khan and Watts, 2009; Watts 2003).

In model $2 \mathrm{a}$, if the coefficient on $L C$ is positive and statistically significant, it indicates that following the conduct that gave rise to a securities lawsuit, firms adopt a higher level of accounting conservatis $\mathrm{m}$. In model $2 \mathrm{~b}$, if the coefficient on $L F$ is positive and statistically significant, it indicates that following the filing of a securities lawsuit, firms adopt a higher level of accounting conservatism. 
Table 5-5 presents the results of the estimation of model 2a. The results of model 2a show the coefficient on LC (0.077) is positive and statistically significant at the $1 \%$ level, indicating that, following the conduct that gave rise to a securities lawsuit, firms adopt a higher level of accounting conservatism. The results of the estimation of model $2 \mathrm{a}$ thus provide support for hypothesis one.

Table 5-6 presents the results of the estimations of model $2 \mathrm{~b}$. The results of model $2 \mathrm{~b}$ show the coefficient on $L F(0.090)$ is positive and statistically significant at the $1 \%$ level, indicating that, following the filing of a securities lawsuit, firms adopt a higher level of accounting conservatism. The results of the estimation of model $2 b$ thus provide support for hypothesis one. 
Table 5-5: Model 2a Regression Results

\begin{tabular}{|c|c|c|c|c|}
\hline & Predicted Sign & Coefficient & $p$-value & $t$-Statistic \\
\hline$\overline{L C}$ & + & 0.077 & $0.000 * * *$ & 12.34 \\
\hline Size & - & -0.009 & $0.000 * * *$ & -4.77 \\
\hline$M B$ & + & 0.003 & $0.000 * * *$ & 9.05 \\
\hline Lev & + & 0.034 & $0.022 * *$ & 2.29 \\
\hline$R V$ & + & 1.580 & 0.212 & -1.25 \\
\hline$C F O$ & - & -0.002 & 0.913 & -0.11 \\
\hline$S G$ & + & 4.870 & 0.608 & 0.51 \\
\hline$R D E$ & + & -0.002 & 0.494 & -0.68 \\
\hline$R D E \_D U M$ & $?$ & 0.004 & 0.567 & 0.57 \\
\hline Intercept & $?$ & 0.173 & $0.000 * * *$ & 0.00 \\
\hline$\overline{R^{2}}$ & \multicolumn{4}{|l|}{0.122} \\
\hline Adjusted $R^{2}$ & \multicolumn{4}{|l|}{0.120} \\
\hline$N$ & \multicolumn{4}{|l|}{4,087} \\
\hline \multicolumn{5}{|c|}{$\begin{array}{l}\text { This table presents the regression results based on the pooled lawsuit and final financial sample from } 1999 \text { to } 2012 . L C \text { is as described in section } 4.3 .1 . S i z e \text { is the natural } \\
\log \text { of market value of equity. } M B \text { is the market-to-book ratio. } L e v \text { is the sum of long-term and short-term debt divided by market value of equity. } R V \text { is the standard } \\
\text { deviation of the change in revenue over the previous five years. } C F O \text { is cash flow before extraordinary items, deflated by total assets. } S G \text { is the percentage change in } \\
\text { sales from }{ }_{\mathrm{t}-1} \text { to }{ }_{\mathrm{t}} . R D E \text { is research and development expense plus advertising divided by the net sales. The methodology follows Francis et al. ( } 2004 \text { ) with missing data } \\
\text { given a value of zero. } R D E \_D U M \text { is equal to one for firms which report zero } R D E \text { and zero otherwise. *,**, and } * * * \text { denote (1-Tailed) significance at the } 0.1,0.05 \text { and } \\
0.01 \text { levels respectively. }\end{array}$} \\
\hline
\end{tabular}


Table 5-6: Model 2b Regression Results

\begin{tabular}{|c|c|c|c|c|}
\hline & Predicted Sign & Coefficient & $p$-value & $t$-Statistic \\
\hline$L F$ & + & 0.090 & $0.000^{* * * *}$ & 14.64 \\
\hline Size & - & -0.011 & $0.000 * * *$ & -5.96 \\
\hline$M B$ & + & -0.002 & 0.457 & -0.74 \\
\hline Lev & + & 0.025 & $0.084 * *$ & 1.73 \\
\hline$R V$ & + & -9.450 & 0.187 & -1.32 \\
\hline $\mathrm{CFO}$ & - & 0.016 & 0.458 & 0.74 \\
\hline$S G$ & + & 4.390 & 0.458 & 0.45 \\
\hline$R D E$ & + & 0.002 & 0.620 & 0.50 \\
\hline$R D E_{-} D U M$ & $?$ & 0.004 & 0.614 & 0.50 \\
\hline Intercept & $?$ & 0.185 & $0.000 * * *$ & 12.87 \\
\hline$\overline{R^{2}}$ & \multicolumn{4}{|l|}{0.145} \\
\hline Adjusted $R^{2}$ & \multicolumn{4}{|l|}{0.143} \\
\hline$N$. & \multicolumn{4}{|l|}{4,305} \\
\hline \multicolumn{5}{|c|}{$\begin{array}{l}\text { This table presents the regression results based on the pooled lawsuit and final financial sample from } 1999 \text { to } 2012 . L F \text { is as described in section } 4.3 .2 . \text { Size is the natural } \\
\log \text { of market value of equity. } M B \text { is the market-to-book ratio. } L e v \text { is the sum of long-term and short-term debt divided by market value of equity. } R V \text { is the standard } \\
\text { deviation of the change in revenue over the previous five years. } C F O \text { is cash flow before extraordinary items, deflated by total assets. } S G \text { is the percentage change in } \\
\text { sales from }{ }_{t-1} \text { to } t . R D E \text { is research and development expense plus advertising divided by the net sales. The methodology follows Francis et al. (2004) with missing data } \\
\text { given a value of zero. } R D E \_D U M \text { is equal to one for firms which report zero } R D E \text { and zero otherwise. *,**, and *** denote (1-Tailed) significance at the } 0.1,0.05 \text { and } \\
0.01 \text { levels respectively. }\end{array}$} \\
\hline
\end{tabular}




\subsubsection{The Impact of Governance (H3 and H4)}

Hypotheses three and four are tested using models $3 \mathrm{a}$ and $3 \mathrm{~b}$ respectively, as specified in Table 4-6. Models $3 \mathrm{a}$ and $3 \mathrm{~b}$ are based on the governance sample and the lawsuit sample. Models $3 \mathrm{a}$ and $3 \mathrm{~b}$ have Cscore as the dependent variable. The lawsuit variable in model $3 \mathrm{a}$ is $L C$, as described in section 4.3.1. The lawsuit variable in model $3 \mathrm{~b}$ is $L F$, as described in section 4.3.2. Financial and governance variables which have been noted in the literature as impacting on accounting conservatism are included as controls (Ahmed and Duellman, 2007; Khan and Watts, 2009; Watts 2003). Models 3a and 3b include lawsuit variables interacted with governance variables as defined in Table 4-7.

In model $3 \mathrm{a}$, if the coefficient on $L C$ is positive and statistically significant, it indicates that following the conduct that gave rise to a securities lawsuit, firms adopt a higher level of accounting conservatis m. If the coefficients on the interacted lawsuit governance variables, as defined in Table 4-7, are statistically significant and either positive or negative it indicates that the corporate governance moderates the association between the conduct that gave rise to a lawsuit and the adoption of a higher level of accounting conservatism.

In model $3 b$, if the coefficient on $L F$ is positive and statistically significant, it indicates that following the filing of a lawsuit, firms adopt a higher level of accounting conservatism. If the coefficients on the interacted lawsuit governance variables, as defined in Table 4-7, are statistically significant and either positive or negative it indicates that the corporate governance variable used in the lawsuit governance variable 
moderates the association between the filing of a lawsuit and the adoption of a higher level of accounting conservatism.

Table 5-7 presents the estimation of model $3 \mathrm{a}$. The results for model 3a show the coefficients on $L C$, the governance variables, and the interacted lawsuit governance variables were not statistically significant. Therefore, the results of the estimation of model $3 \mathrm{a}$ do not provide support for hypothesis three.

Table 5-8 presents the estimation of model $3 \mathrm{~b}$. The results for model $3 \mathrm{~b}$ show that the coefficient on $L F \_B M(-0.004)$ was found to be negative and statistically significant at the $10 \%$ level. However, the coefficients on $L F$, and the other interacted lawsuit governance variables were not statistically significant. The results of model $3 \mathrm{~b}$ thus provide limited support for hypothesis four, in respect of board meetings, but the lawsuit variable is not significant.

Table 5-9 reports the variance inflation factors for models $3 a$, and $3 b$. The results indicate an absence of multicollinearity problems. 
Table 5-8: Model 3b Regression Results

\begin{tabular}{|c|c|c|c|c|}
\hline & Predicted Sign & Coefficient & $p$-value & $t$-Statistic \\
\hline$L F$ & + & 0.010 & 0.911 & 0.11 \\
\hline Size & - & -0.011 & $0.002 * * *$ & -3.05 \\
\hline$M B$ & + & 0.000 & 0.749 & 0.32 \\
\hline Lev & + & -0.003 & 0.904 & -0.12 \\
\hline$R V$ & + & -4.870 & 0.633 & -0.48 \\
\hline CFO & - & -0.004 & 0.911 & -0.11 \\
\hline$S G$ & + & 9.360 & 0.436 & 0.78 \\
\hline$R D E$ & + & 0.009 & 0.304 & 1.03 \\
\hline$R D E \_D U M$ & $?$ & 0.001 & 0.329 & 0.98 \\
\hline$A F$ & $?$ & 0.001 & 0.377 & 0.88 \\
\hline$B S$ & $?$ & -0.001 & 0.714 & -0.37 \\
\hline$B M$ & $?$ & 0.004 & $0.042 * *$ & 1.94 \\
\hline$O D$ & + & 0.027 & 0.737 & 0.34 \\
\hline$L F \_A F$ & $?$ & 0.140 & 0.755 & 0.31 \\
\hline$L F \_B S$ & $?$ & -0.002 & 0.557 & -0.59 \\
\hline$L F \_B M$ & $?$ & -0.004 & $0.071^{*}$ & -1.81 \\
\hline$L F \_O D$ & $?$ & 0.150 & 0.170 & 1.37 \\
\hline Intercept & $?$ & 0.163 & 0.018 & 2.38 \\
\hline$\overline{R^{2}}$ & 0.156 & & & \\
\hline Adjusted $R^{2}$ & 0.150 & & & \\
\hline
\end{tabular}

This table presents the regression results based on the pooled lawsuit and governance sample from 1999 to 2012. $L F$ is as described in section 4.3.2. Size is the natural log of market value of equity. $M B$ is the market-to-book ratio. $L e v$ is the sum of long-term and short-term debt divided by market value of equity. $R V$ is the standard deviation of the change in revenue over the previous five years. $C F O$ is cash flow before extraordinary items, deflated by total assets. $S G$ is the percentage change in sales from $\mathrm{t}_{\mathrm{t}-1} \mathrm{to}_{\mathrm{t}} \cdot R D E$ is research and development expense plus advertising divided by the net sales. The methodology follows Francis et al. (2004) with missing data given a value of zero. $R D E \_D U M$ is equal to one for firms which report zero $R D E$ and zero otherwise. $A F$ is the total amount of audit fees deflated by total assets. $B S$ is the total number of directors on the board. $B M$ is the total number of board meetings. $O D$ is the number of outside directors on the board divided by the total number of directors on the board. $L F \_A F$ is $L F$ interacted with $A F$. $L F \_B S$ is $L F$ interacted with $B S$. $L F \_B M$ is $L F$ interacted with $B M . L F \_O D$ is $L F$ interacted with $O D . *, * *$, and $* * *$ denote (2-Tailed) significance at the $0.1,0.05$ and 0.01 levels respectively. 
Table 5-9: Variance Inflation Factor

\begin{tabular}{lcc}
\hline & Model 3a & Model 3b \\
\hline Size & 2.04 & 1.95 \\
$B S$ & 1.84 & 1.80 \\
Lev & 1.57 & 1.49 \\
$R V$ & 1.36 & 1.24 \\
$R D E \_D U M$ & 1.29 & 1.26 \\
$C F O$ & 1.20 & 1.18 \\
$M B$ & 1.16 & 1.06 \\
$O D$ & 1.14 & 1.16 \\
$A F$ & 1.13 & 1.13 \\
$B M$ & 1.09 & 1.09 \\
$L C$ & 1.07 & $\mathrm{~N} / \mathrm{A}$ \\
$L F$ & $\mathrm{~N} / \mathrm{A}$ & 1.08 \\
$R D E$ & 1.05 & 1.05 \\
$S G$ & 1.01 & 1.01 \\
Mean & 1.30 & 1.27 \\
\hline$N$. & 2,204 & 2,490 \\
\hline
\end{tabular}

This table shows the variance inflation factor for Model 3 a and Model 3 b. $L C$ is as described in section

4.3.1. $L F$ is as described in section 4.3.2. Size is the natural $\log$ of market value of equity. $M B$ is the market-to-book ratio. Lev is the sum of long-term and short-term debt divided by market value of equity. $R V$ is the standard deviation of the change in revenue over the previous five years. $C F O$ is cash flow before extraordinary items, deflated by total assets. $S G$ is the percentage change in sales from ${ }_{t-1}$ to ${ }_{t} . R D E$ is research and development expense plus advertising divided by the net sales. The methodology follows Francis et al. (2004) with missing data given a value of zero. $R D E \_D U M$ is equal to one for firms which report zero $R D E$ and zero otherwise. $A F$ is the total amount of audit fees deflated by total assets. $B S$ is the total number of directors on the board. $B M$ is the total number of board meetings. $O D$ is the number of out side directors on the board divided by the total number of directors on the board. 


\subsection{Robustness Testing}

\subsubsection{Lagged Conservatism (H1 and H2)}

Khan and Watts (2009) noted that the prior level of accounting conservatism (Cscore $\left._{(t-1)}\right)$ is expected to influence the current level of accounting conservatism. To ensure the tests of hypotheses one and two are robust to prior year use of accounting conservatism, this study estimates models $4 \mathrm{a}$ and $4 \mathrm{~b}$ respectively, as specified in Table 4-13.

Models $4 \mathrm{a}$ and $4 \mathrm{~b}$ have as the dependent variable Cscore. The lawsuit variable in model $4 \mathrm{a}$ is $L C$. The lawsuit variable in model $4 \mathrm{~b}$ is $L F$. In model $4 \mathrm{a}$, if the coefficient on $L C$ is positive and statistically significant, it indicates that the results of model $2 \mathrm{a}$ are robust to $\operatorname{Cscore}_{(t-1)}$ and provides additional support for hypothesis one. In model $4 \mathrm{~b}$, if the coefficient on $L F$ is positive and statistically significant, it indicates that the findings of model $2 \mathrm{~b}$ are robust to Cscore $_{(t-1)}$ and provides additional support for hypothesis two.

Table 5-10 presents the estimates of model 4a. The results for model $4 \mathrm{a}$ show that the coefficient on $L C(0.077)$ is positive and statistically significant at the $1 \%$ level. This finding indicates that model $4 \mathrm{a}$ is robust to $\operatorname{Cscore}_{(t-1)}$. This finding also supports the acceptance of hypothesis one. The signs on the coefficients of the control variables Size, $M B$, and $L e v$ are consistent with the predicted signs stated in Table 4-5. The coefficient on $\operatorname{Cscore}_{(t-1)}(0.002)$ is positive and statistically significant at the 5\% level. This finding is consistent with Khan and Watts (2009).

Table 5-11 presents the estimates of model $4 \mathrm{~b}$. The results for model $4 \mathrm{~b}$ show that the coefficient on $L F(0.089)$ is positive and statistically significant at the $1 \%$ level. This finding indicates that model $2 \mathrm{~b}$ is robust to Cscore $(t-1)$. This finding also supports the acceptance of hypothesis two. The signs on the coefficients of the control variables Size, $M B$, and $L e v$ are consistent with the predicted signs stated in Table 4-5. The coefficient on Cscore $_{(t-1)}(0.003)$ is positive and statistically significant at the $1 \%$ level. This finding is consistent with Khan and Watts (2009). 
Table 5-10: Model 4a Regression Results

\begin{tabular}{|c|c|c|c|c|}
\hline & Predicted Sign & Coefficient & p-value & t-Statistic \\
\hline $\operatorname{Cscore}_{(t-1)}$ & + & 0.002 & $0.043^{* *}$ & 2.02 \\
\hline$L C$ & + & 0.077 & $0.000 * * *$ & 12.37 \\
\hline Size & - & -0.009 & $0.000 * * *$ & -4.78 \\
\hline$M B$ & + & 0.003 & $0.000 * * *$ & 9.02 \\
\hline Lev & + & 0.034 & $0.022 * *$ & 2.29 \\
\hline$R V$ & + & -1.570 & 0.215 & -1.24 \\
\hline$C F O$ & - & -0.003 & 0.887 & -0.14 \\
\hline$S G$ & + & 4.800 & 0.613 & 0.51 \\
\hline$R D E$ & + & -0.000 & 0.496 & -0.68 \\
\hline$R D E \_D U M$ & $?$ & 0.004 & 0.550 & 0.60 \\
\hline Intercept & $?$ & 0.171 & $0.000 * * *$ & 11.92 \\
\hline$\overline{R^{2}}$ & \multicolumn{4}{|l|}{0.128} \\
\hline$\overline{\text { Adjusted } R^{2}}$ & \multicolumn{4}{|l|}{0.126} \\
\hline $\bar{N}$. & \multicolumn{4}{|l|}{4,087} \\
\hline \multicolumn{5}{|c|}{ 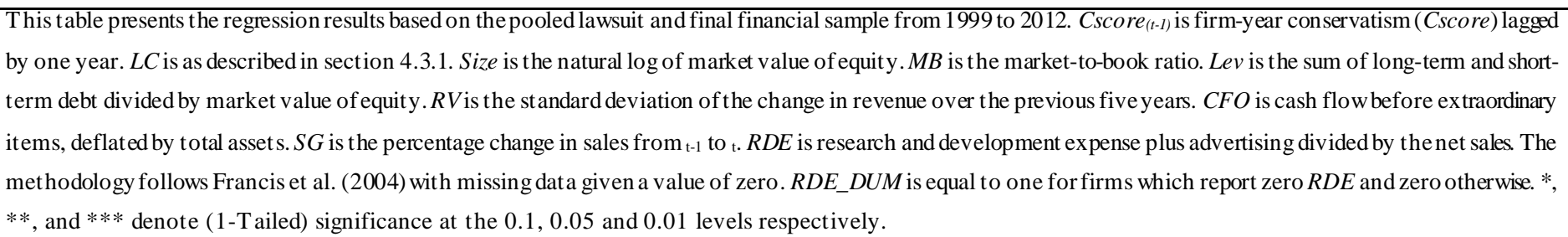 } \\
\hline
\end{tabular}


Table 5-11: Model 4b Regression Results

\begin{tabular}{|c|c|c|c|c|}
\hline & Predicted Sign & Coefficient & $p$-value & $t$-Statistic \\
\hline $\operatorname{Cscore}_{(t-1)}$ & + & 0.003 & $0.012 * * *$ & 2.50 \\
\hline$L F$ & + & 0.089 & $0.000 * * *$ & 14.65 \\
\hline Size & - & -0.011 & $0.000 * * *$ & -5.98 \\
\hline$M B$ & + & -0.000 & 0.430 & -0.79 \\
\hline Lev & + & 0.025 & $0.083^{*}$ & 1.74 \\
\hline$R V$ & + & -9.510 & 0.188 & -1.32 \\
\hline CFO & - & 0.015 & 0.484 & 0.70 \\
\hline$S G$ & + & 4.310 & 0.657 & 0.44 \\
\hline$R D E$ & + & 0.000 & 0.623 & 0.49 \\
\hline$R D E \_D U M$ & $?$ & 0.004 & 0.590 & 0.54 \\
\hline Intercept & $?$ & 0.184 & $0.000 * * *$ & 12.81 \\
\hline$\overline{R^{2}}$ & \multicolumn{4}{|l|}{0.153} \\
\hline Adjusted $R^{2}$ & \multicolumn{4}{|l|}{0.151} \\
\hline$N$ & \multicolumn{4}{|l|}{4,305} \\
\hline \multicolumn{5}{|c|}{ 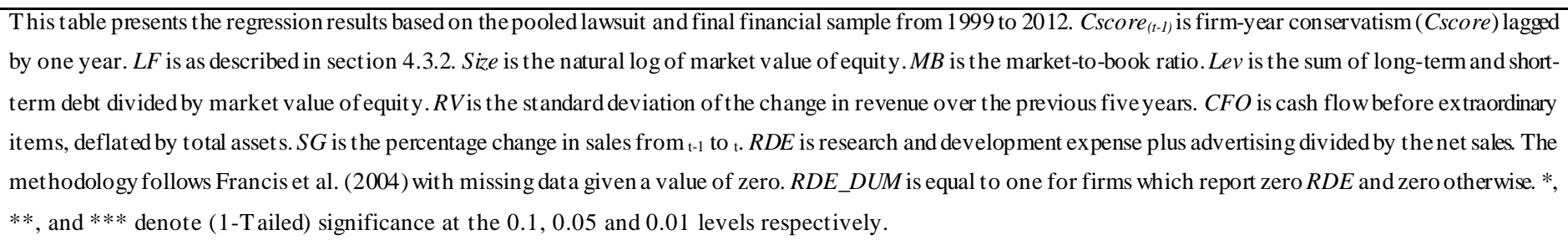 } \\
\hline
\end{tabular}


To ensure the tests of hypotheses one, two, three, and four are robust to an alternative lawsuit measurement, this study estimates model 2aa, 2bb, 3aa, 3bb, 4aa, and 4bb with the alternative lawsuit measurements $L C S$ and $L F S$ respectively, as specified in Table 4-16.

The lawsuit variable in models $2 \mathrm{aa}, 3 \mathrm{aa}$, and $4 \mathrm{aa}$ is $L C S$. The lawsuit variable in models $2 \mathrm{bb}, 3 \mathrm{bb}$, and $4 \mathrm{bb}$ is $L F S$. Financial and governance variables which have been noted in the literature as impacting on accounting conservatism are included as controls (Ahmed and Duellman, 2007; Khan and Watts, 2009; Watts 2003).

In models $2 \mathrm{aa}, 3 \mathrm{aa}$, and $4 \mathrm{aa}$, if the coefficient on $L C S$ is positive and statistically significant, it indicates that the findings of models $2 \mathrm{a}, 3 \mathrm{a}$, and $4 \mathrm{a}$ respectively are robust to a shorter lawsuit measurement window and supports the acceptance of hypothesis one. If the results of model 3aa show that the coefficient on a lawsuit governance interaction variable is statistically significant and either positive or negative it provides support for hypothesis three.

In models $2 \mathrm{bb}, 3 \mathrm{bb}$, and $4 \mathrm{bb}$, if the coefficient on $L F S$ is positive and statistically significant, it indicates that the findings of models $2 \mathrm{~b}, 3 \mathrm{~b}$ and $4 \mathrm{~b}$ respectively are robust to a shorter lawsuit measurement window and supports the acceptance of hypothesis two. If the results of model $3 \mathrm{bb}$ show that the coefficient on a lawsuit governance interaction variable is statistically significant and either positive or negative it provides support for hypothesis four. 
Table 5-12 presents the results of the estimation of model $2 \mathrm{aa}$. The results show that the coefficient on $\operatorname{LCS}(0.061)$ is positive and statistically significant at the $1 \%$ level. This finding indicates that model $2 \mathrm{a}$ is robust to a shorter lawsuit measurement window and provides support for the acceptance of hypothesis one.

Table 5-13 presents the results of the estimation of model $2 \mathrm{bb}$. The results show that the coefficient on $\operatorname{LFS}(0.054)$ is positive and statistically significant at the $1 \%$ level. This finding indicates that model $2 \mathrm{~b}$ is robust to a shorter lawsuit measurement window and provides support for the acceptance of hypothesis two.

Table 5-14 presents the estimation of model $3 \mathrm{aa}$. The results show that the coefficient on the $L C S \_B M(0.010)$ is statistically significant at the $10 \%$ level and positive, thus supporting hypothesis three, in respect of board meetings. However, the results also show that the coefficients on LCS and the coefficients on the other lawsuit governance interacted variables, as defined in Table 4-7, are not statistically significant.

Table 5-15 presents the estimation of model $3 \mathrm{bb}$. The results show that the coefficie nt on LFS and the lawsuit governance interacted variables, as defined in Table 4-7, are not statistically significant. Table 5-16 reports on the variance inflation factors for models $3 \mathrm{aa}$ and $3 \mathrm{bb}$ and indicates the absence of multicollinearity.

Table 5-17 presents the estimates of model $4 \mathrm{aa}$. The results show that the coefficient on $\operatorname{LCS}(0.034)$ is positive and statistically significant at the $1 \%$ level. This finding indicates that model $4 \mathrm{aa}$ is robust to a shorter lawsuit measurement window and 
provides further support for the adoption of hypothesis one. The resulting coefficient on $\operatorname{Cscore}_{(t-1)}(0.005)$ is also positive and statistically significant at the $1 \%$ level. This finding is consistent with the findings of Khan and Watts (2009).

Table 5-18 presents the estimates of model $4 \mathrm{bb}$. The results of model $4 \mathrm{bb}$ show the coefficient on LFS (0.034) is positive and statistically significant at the $1 \%$ level. This finding indicates that model $4 \mathrm{bb}$ is robust to a shorter lawsuit measurement window and provides support for the adoption of hypothesis two. The resulting coefficient on $\operatorname{Cscore}(t-1)_{(0.006)}$ is also positive and statistically significant at the $1 \%$ level. This finding is consistent with the findings of Khan and Watts (2009). 
Table 5-12: Model 2aa Regression Results

\begin{tabular}{|c|c|c|c|c|}
\hline & Predicted Sign & Coefficient & $p$-value & t-Statistic \\
\hline$L C S$ & + & 0.061 & $0.000 * *$ & 0.98 \\
\hline Size & - & -0.008 & $0.000 * * *$ & -3.56 \\
\hline$M B$ & + & 0.002 & $0.000 * * *$ & 9.58 \\
\hline Lev & + & 0.037 & $0.032 * *$ & 2.15 \\
\hline$R V$ & + & -2.350 & 0.111 & -1.60 \\
\hline $\mathrm{CFO}$ & - & -0.001 & 0.937 & -0.08 \\
\hline$S G$ & + & 0.000 & 0.305 & 1.03 \\
\hline$R D E$ & + & -0.000 & 0.550 & -0.60 \\
\hline$R D E \_D U M$ & $?$ & 0.012 & 0.148 & 1.45 \\
\hline Intercept & $?$ & 0.178 & $0.000 * * *$ & 10.15 \\
\hline$R^{2}$ & 0.109 & & & \\
\hline Adjusted $R^{2}$ & 0.106 & & & \\
\hline
\end{tabular}

This table presents the regression results based on the pooled lawsuit and the final financial sample from 1999 to 2012. LCS is as described in section 4.6.2. Size is the natural log of market value of equity. $M B$ is the market-to-book ratio. $L e v$ is the sum of long-term and short-term debt divided by market value of equity. $R V$ is the standard deviation of the change in revenue over the previous five years. $C F O$ is cash flow before extraordinary items, deflated by total assets. $S G$ is the percentage change in sales from ${ }_{\mathrm{t}-1}$ to ${ }_{\mathrm{t}} . R D E$ is research and development expense plus advertising divided by the net sales. The methodology follows Francis et al. (2004) with missing data given a value of zero. $R D E \_D U M$ is equal to one for firms which report zero $R D E$ and zero otherwise. *,**, and *** denote (1-T ailed) significance at the $0.1,0.05$ and 0.01 levels respectively. 


\section{Table 5-13: Model 2bb Regression Results}

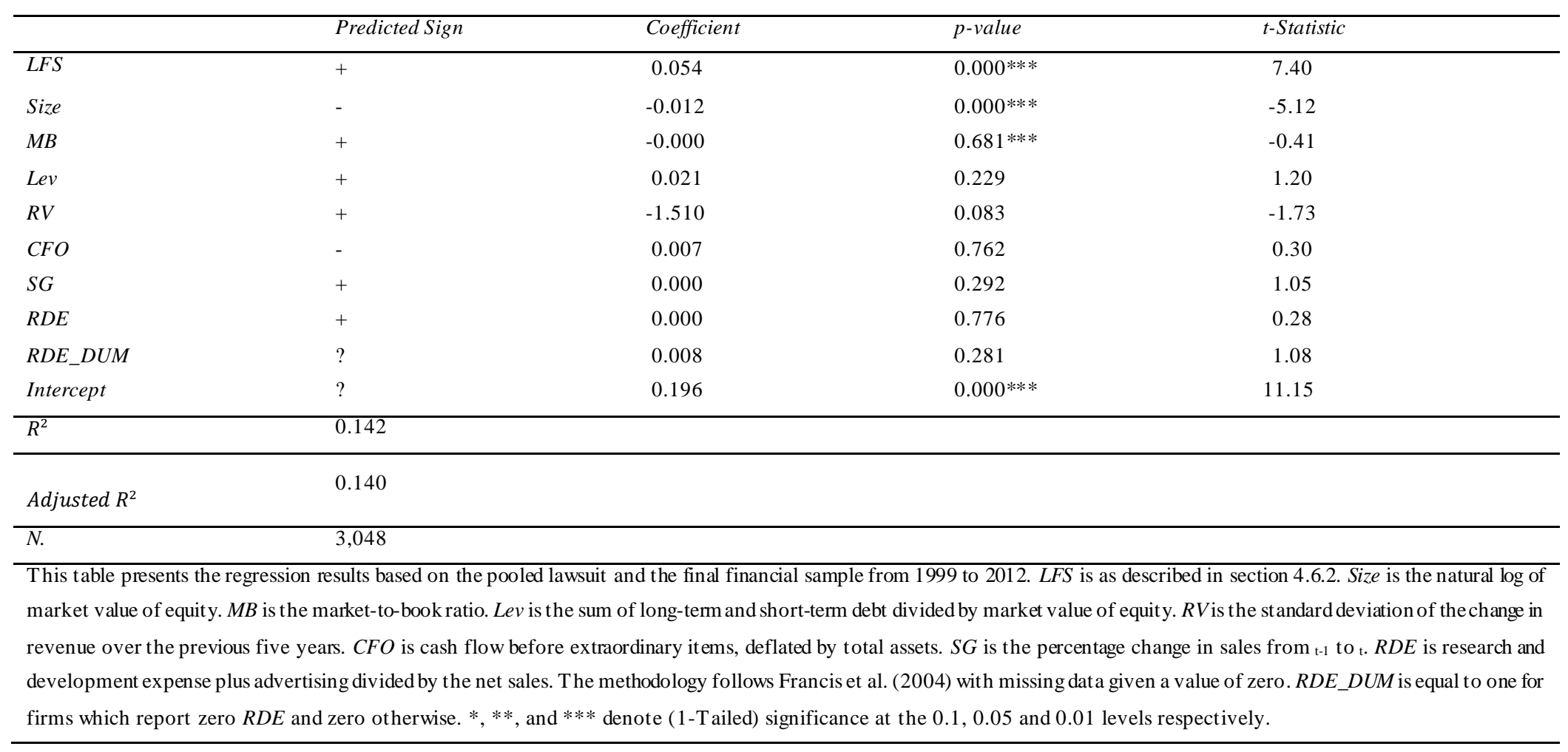


Table 5-14: Model 3aa Regression Results

\begin{tabular}{|c|c|c|c|c|}
\hline & Predicted Sign & Coefficient & $p$-value & t-Statistic \\
\hline$L C S$ & + & -0.109 & 0.559 & -0.58 \\
\hline Size & - & -0.052 & $0.000 * * *$ & -6.76 \\
\hline$M B$ & + & -0.001 & 0.390 & -0.86 \\
\hline Lev & + & 0.396 & $0.000 * * *$ & 7.84 \\
\hline$R V$ & + & -5.250 & 0.187 & -1.32 \\
\hline$C F O$ & - & 0.095 & 0.229 & 1.20 \\
\hline$S G$ & + & 0.000 & 0.322 & 0.99 \\
\hline$R D E$ & + & 0.000 & 0.986 & 0.02 \\
\hline$R D E \_D U M$ & $?$ & 0.013 & 0.521 & 0.64 \\
\hline$A F$ & $?$ & 0.006 & 0.763 & 0.30 \\
\hline$B S$ & $?$ & 0.004 & 0.519 & 0.65 \\
\hline$B M$ & $?$ & -0.002 & 0.697 & -0.39 \\
\hline$O D$ & + & -0.098 & 0.582 & -0.55 \\
\hline$L C S \_A F$ & $?$ & 0.000 & 0.124 & 2.26 \\
\hline$L C S \_B S$ & $?$ & -0.006 & 0.420 & -0.81 \\
\hline$L C S \_B M$ & $?$ & 0.010 & $0.090^{*}$ & 1.02 \\
\hline$L C S \_O D$ & $?$ & 0.184 & 0.414 & 0.82 \\
\hline Intercept & $?$ & 0.239 & 0.108 & 1.61 \\
\hline$\overline{R^{2}}$ & 0.155 & & & \\
\hline Adjusted $R^{2}$ & 0.146 & & & \\
\hline
\end{tabular}

This table presents the regression results based on the pooled lawsuit and governance sample from 1999 to 2012. LCS is as described in section 4.6.2. Size is the natural log of market value of equity. $M B$ is the market-to-book ratio. $L e v$ is the sum of long-term and short-term debt divided by market value of equity. $R V$ is the standard deviation of the change in revenue over the previous five years. $C F O$ is cash flow before extraordinary items, deflated by total assets. $S G$ is the percentage change in sales from $\mathrm{t}_{\mathrm{t}-1} \mathrm{to}_{\mathrm{t}}$. $R D E$ is research and development expense plus advertising divided by the net sales. The methodology follows Francis et al. (2004) with missing data given a value of zero. $R D E \_D U M$ is equal to one for firms which report zero $R D E$ and zero otherwise. $A F$ is the total amount of audit fees deflated by total assets. $B S$ is the total number of directors on the board. $B M$ is the totalnumber of board meetings. $O D$ is the number of outside directors on the board divided by the total number of directors on the board. $L C S \_A F$ is $L C S$ interacted with $A F$. $L C S \_B S$ is $L C S$ interacted with $B S$. $L C S \_B M$ is $L C S$ interacted with $B M$. LCS_OD is $L C S$ interacted with $O D . *, * *$, and *** denote (2-Tailed) significance at the $0.1,0.05$ and 0.01 levels respectively. 
Table 5-15: Model 3bb Regression Results

\begin{tabular}{|c|c|c|c|c|}
\hline & Predicted Sign & Coefficient & $p$-value & $t$-Statistic \\
\hline$L F S$ & + & -0.084 & 0.616 & -0.50 \\
\hline Size & - & -0.047 & $0.000 * * *$ & -6.50 \\
\hline$M B$ & + & 0.001 & 0.324 & 0.99 \\
\hline Lev & + & 0.378 & $0.000 * * *$ & 8.34 \\
\hline$R V$ & + & -2.560 & 0.202 & -1.28 \\
\hline CFO & - & 0.061 & 0.418 & 0.81 \\
\hline$S G$ & + & 0.000 & 0.335 & 0.97 \\
\hline$R D E$ & + & 0.001 & 0.695 & 0.39 \\
\hline$R D E \_D U M$ & $?$ & 0.009 & 0.619 & 0.50 \\
\hline$A F$ & $?$ & 0.005 & 0.434 & 0.78 \\
\hline$B S$ & $?$ & -0.004 & 0.431 & -0.79 \\
\hline$B M$ & $?$ & 0.003 & 0.383 & 0.87 \\
\hline$O D$ & + & 0.056 & 0.704 & -0.38 \\
\hline$L F S \_A F$ & $?$ & 1.740 & 0.833 & 0.21 \\
\hline$L F S \_B S$ & $?$ & -0.000 & 0.951 & -0.06 \\
\hline$L F S \_B M$ & $?$ & -0.005 & 0.216 & -1.24 \\
\hline$L F S \_O D$ & $?$ & 0.286 & 0.157 & 1.42 \\
\hline Intercept & $?$ & 0.194 & 0.124 & 1.54 \\
\hline$\overline{R^{2}}$ & 0.143 & & & \\
\hline Adjusted $R^{2}$ & 0.135 & & & \\
\hline N. & 1,858 & & & \\
\hline
\end{tabular}

This table presents the regression results based on the pooled lawsuit and governance sample from 1999 to 2012. LFS is as described in section 4.6.2. Size is the natural $\log$ of market value of equity. $M B$ is the market-to-book ratio. $L e v$ is the sum of long-term and short-term debt divided by market value of equity. $R V$ is the st andard deviation of the change in revenue over the previous five years. $C F O$ is cash flow before extraordinary items, deflated by total assets. $S G$ is the percentage change in sales from $\mathrm{t}_{-1}$ to $\mathrm{t}$. $R D E$ is research and development expense plus advertising divided by the net sales. The methodology follows Francis et al. (2004) with missing data given a value of zero. $R D E \_D U M$ is equal to one for firms which report zero $R D E$ and zero otherwise. $A F$ is the total amount of audit fees deflated by total assets. $B S$ is the total number of directors on the board. $B M$ is the total number of board meetings. $O D$ is the number of out side directors on the board divided by the total number of directors on the board. $L F S \_A F$ is $L F S$ interacted with $A F$. LFS_BS is $L F S$ interacted with $B S . L F S \_B M$ is $L F S$ interacted with $B M$. LFS_OD is $L F S$ interacted with $O D . *, *$, and $* * *$ denote (2-Tailed) significance at the $0.1,0.05$ and 0.01 levels respectively. 
Table 5-16: Variance Inflation Factor

\begin{tabular}{lll}
\hline & Model 3aa & Model 3bb \\
\hline Size & 2.02 & 2.16 \\
$B S$ & 1.92 & 1.81 \\
Lev & 1.59 & 1.48 \\
$R V$ & 1.37 & 1.25 \\
$R D E \_D U M$ & 1.32 & 1.28 \\
$C F O$ & 1.19 & 1.17 \\
$M B$ & 1.17 & 1.07 \\
$O D$ & 1.15 & 1.15 \\
$A F$ & 1.11 & 1.36 \\
$B M$ & 1.10 & 1.08 \\
$R D E$ & 1.07 & 1.05 \\
$L F S$ & N/A & 1.07 \\
$L C S$ & 1.07 & N/A \\
$S G$ & 1.01 & 1.01 \\
$M e a n$ & 1.31 & 1.30 \\
\hline$N$. & 1,541 & 1,858 \\
\hline
\end{tabular}

This table shows the variance inflation factor for $3 \mathrm{aa}$, and 3bb. $L F S$ is as described in section 4.6.2. $L C S$ is as described in section 4.6.2. Size is the natural log of market value of equity. $M B$ is the market-to-book ratio. Lev is the sum of long-term and short-term debt divided by market value of equity. $R V$ is the standard deviation of the change in revenue over the previous five years. $C F O$ is cash flow before extraordinary items, deflated by total assets. $S G$ is the percentage change in sales from $\mathrm{t}_{-1}$ to $\mathrm{t} . R D E$ is research and development expense plus advertising divided by the net sales. The methodology follows Francis et al. (2004) with missing data given a value of zero. $R D E \_D U M$ is equal to one for firms which report zero $R D E$ and zero otherwise. $A F$ is the total amount of audit fees deflated by total assets. $B S$ is the total number of directors on the board. $B M$ is the total number of board meetings. $O D$ is the number of outside directors on the board divided by the total number of directors on the board. *,**, and *** denote (2-Tailed) significance at the $0.1,0.05$ and 0.01 levels respectively. 
Table 5-17: Model 4aa Regression Results

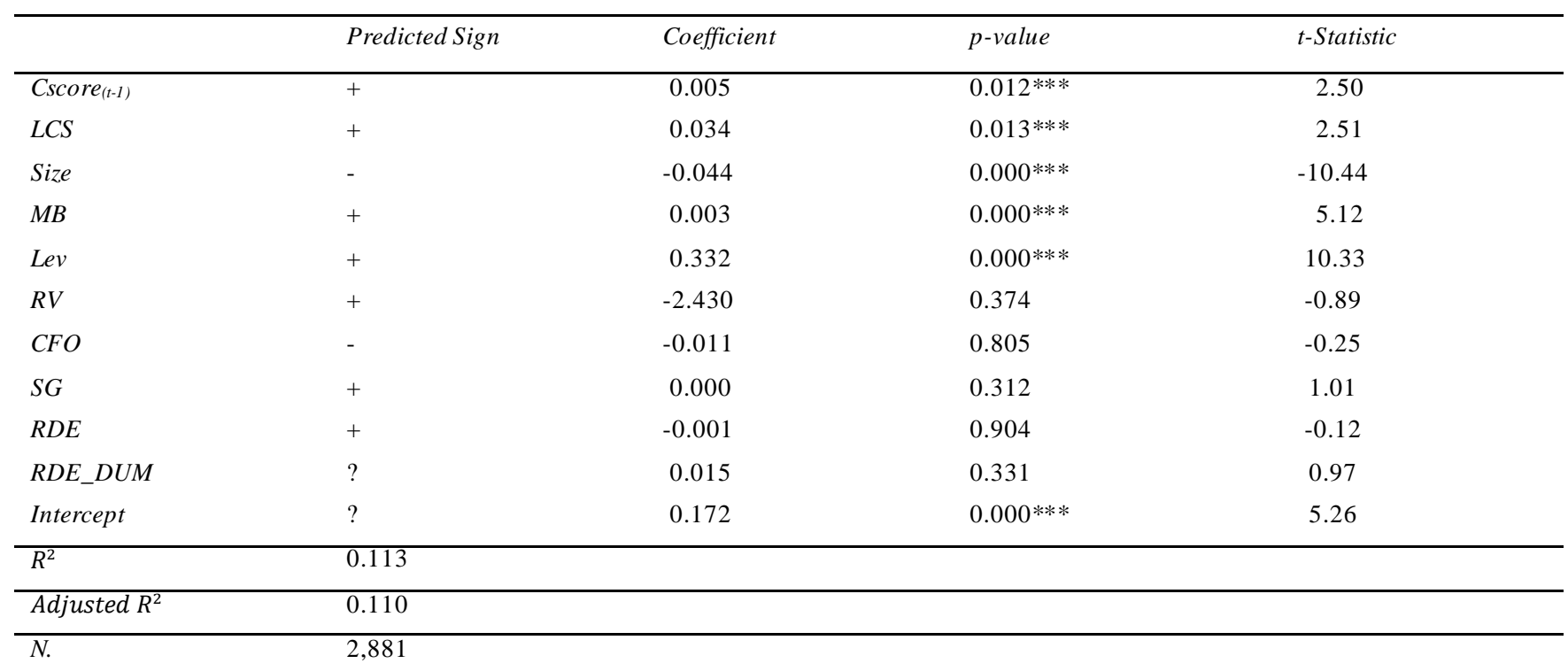

This table presents the regression results based on the pooled lawsuit and the final financial sample from 1999 to 2012. Cscore $_{(t-1)}$ is firm-year conservatism (Cscore) lagged by one year. LCS is as described in section 4.6.2. Size is the natural log of market value of equity. MB is the market-to-book ratio. Lev is the sum of long-term and short-term debt divided by market value of equity. $R V$ is the st andard deviation of the change in revenue over the previous five years. $C F O$ is cash flow before extraordinary items, deflated by total assets. $S G$ is the percentage change in sales from t-1 to $t_{t} R D E$ is research and development expense plus advertising divided by the net sales. The methodology follows Francis et al. (2004) with missing data given a value of zero. $R D E \_D U M$ is equal to one for firms which report zero $R D E$ and zero otherwise. *,**, and $* * *$ denote (1-Tailed) significance at the $0.1,0.05$ and 0.01 levels respectively. 
Table 5-18: Model 4bb Regression Results

\begin{tabular}{|c|c|c|c|c|}
\hline & Predicted Sign & Coefficient & $p$-value & $t$-Statistic \\
\hline Cscore $_{(t-1)}$ & + & 0.006 & $0.012 * * *$ & 2.50 \\
\hline$L F S$ & + & 0.034 & $0.013 * * *$ & 2.51 \\
\hline Size & - & -0.044 & $0.000 * * *$ & -10.44 \\
\hline$M B$ & + & 0.003 & $0.000 * * *$ & -5.12 \\
\hline Lev & + & 0.332 & $0.000 * * *$ & 10.33 \\
\hline$R V$ & + & -2.430 & 0.374 & -0.89 \\
\hline $\mathrm{CFO}$ & - & -0.011 & 0.805 & -0.25 \\
\hline$S G$ & + & 0.000 & 0.312 & 1.01 \\
\hline$R D E$ & + & -0.000 & 0.904 & -0.12 \\
\hline$R D E \_D U M$ & $?$ & 0.015 & 0.331 & 0.97 \\
\hline Intercept & $?$ & 0.172 & $0.000 * * *$ & 5.26 \\
\hline$R^{2}$ & 0.349 & & & \\
\hline Adjusted $R^{2}$ & 0.347 & & & \\
\hline$N$ & 2,815 & & & \\
\hline
\end{tabular}

This table presents the regression results based on the pooled lawsuit and the final financial sample from 1999 to 2012 . Cscore $(t-1)$ is firm-year conservatism (Cscore) lagged by one year. LFS is as described in section 4.6.2. Size is the natural log of market value of equity. MB is the market-to-book ratio. Lev is the sum of long-term and short-term debt divided by market value of equity. $R V$ is the standard deviation of the change in revenue over the previous five years. $C F O$ is cash flow before extraordinary items, deflated by total assets. $S G$ is the percentage change in sales from ${ }_{\mathrm{t}-1}$ to $_{\mathrm{t}} . R D E$ is research and development expense plus advertising divided by the net sales. The methodology follows Francis et al. (2004) with missing dat a given a value of zero. $R D E \_D U M$ is equal to one for firms which report zero $R D E$ and zero otherwise.*, **, and $* * *$ denote (1-Tailed) significance at the $0.1,0.05$ and 0.01 levels respectively. 


\subsubsection{Alternative Conservatism Measure (H1 and H2)}

To ensure that the results of the tests of hypotheses one and two are robust to an alternative measure of accounting conservatism, models $5 \mathrm{a}$ and $5 \mathrm{~b}$ are estimated, using the Basu $(1995 ; 1997)$ earnings measure of accounting conservatism, as specified in Table 4-17. Additionally, model $5 \mathrm{c}$, and $5 \mathrm{~d}$ are estimated, to ensure that the results using the alternative measure of accounting conservatism are robust to a shorter lawsuit measurement window, as also specified in Table 4-17.

In models $5 \mathrm{a}, 5 \mathrm{~b}, 5 \mathrm{c}$, and $5 \mathrm{~d}$, the dependent variable is $X$, the independent variables include; $R, D$, and $R \_D$. In model 5 a, the lawsuit variable is $L C$ and the interacted lawsuit returns variables are, $L C_{-} R, L C_{-} D$, and $L C \_R \_D$. In model $5 \mathrm{~b}$, the lawsuit variable is $L F$ and the interacted lawsuit returns variables are, $L F_{-} R, L F_{-} D$, and $L F_{-} R_{-} D$. In model $4 \mathrm{c}$, the lawsuit variable is $L C S$ and the interacted lawsuit returns variables are, $L C S \_R, L C S \_D$, and $L C S \_R \_D$. In model $5 \mathrm{~d}$, the lawsuit variable is $L F S$ and the interacted lawsuit returns variables are, $L F S \_R, L F S \_D$, and $L F S \_R \_D$.

In models $5 \mathrm{a}, 5 \mathrm{~b}, 5 \mathrm{c}$, and $5 \mathrm{~d}$, if the coefficient on $R \_D$ is higher than the coefficient on $R$, it indicates that the sample of firms are engaging in the adoption of accounting conservatism (Basu 1997; 1995). In model 5a, when the coefficient on $L C \_R \_D$ is higher than the coefficient on $R \_D$, it indicates the adoption of a higher level of accounting conservatis $m$ following the conduct which gives rise to a lawsuit. In model $5 \mathrm{~b}$, if the coefficient on $L F \_R \_D$ is higher than the coefficient on $R \_D$, it indicates the adoption of higher levels of accounting conservatism, following the 
filing of a lawsuit. In model $5 \mathrm{c}$, if the estimate on $L C S \_R \_D$ is higher than the estimate on the $R \_D$ coefficient it indicates that model $5 \mathrm{a}$ is robust to a shorter lawsuit window. In model $5 \mathrm{~d}$, if the coefficient on $L F S \_R \_D$ is higher than the coefficient on $R \_D$ it indicates that model $5 \mathrm{~b}$ is robust to a shorter lawsuit measurement window.

Table 5-19 presents the estimates of model $5 \mathrm{a}$. The results of model $5 \mathrm{a}$ show the coefficient on $R(-0.037)$ is negative and statistically significant at the $1 \%$ level. The coefficient on $R \_D(0.100)$ is positive and statistically significant at the $1 \%$ level. The incremental difference between the coefficient on $R$ and the coefficient on $R \_D$ indicates that firms are engaging in accounting conservatism. The coefficient on $L C \_R \_D(0.167)$ is positive and statistically significant at the $1 \%$ level. The incremental difference between the estimate on $R \_D$ and the estimate on $L C \_R \_D$ indicates that firms adopt a higher level of accounting conservatism following the conduct which gives rise to a securities lawsuit. This finding is consistent with the findings of model 2a and supports the results obtained using Cscore as the measure of accounting conservatism. The results of the estimation of model $5 \mathrm{a}$ provide further support for the acceptance of hypothesis one.

Table $5-20$ presents the estimates of model $5 \mathrm{~b}$. The results of model $5 \mathrm{~b}$ show the coefficient on $R(-0.031)$ is negative and statistically significant at the $1 \%$ level. The coefficient on $R \_D(0.108)$ is positive and statistically significant at the $1 \%$ level. The incremental difference between the coefficient on $R$ and the coefficient on $R \_D$ indicates that firms are engaging in accounting conservatism. The coefficient on $L F \_R \_D(0.187)$ is positive and statistically significant at the $1 \%$ level. The incremental difference between the coefficient on $R \_D$ and the 
coefficient on $L F \_R \_D$ indicates that firms adopt a higher level of accounting conservatism following the filing of a securities lawsuit. This finding is consistent with model $2 \mathrm{~b}$ and supports the results obtained using Cscore as the measure of accounting conservatism. The results of the estimation of model $5 \mathrm{~b}$ provide further support for the acceptance of hypothesis two.

Table 5-21 presents the estimates of model $5 \mathrm{c}$. The results of model $5 \mathrm{c}$ show the coefficient on $R(-0.039)$ is negative and statistically significant at the $5 \%$ level. The coefficient on $R \_D(0.104)$ is positive and statistically significant at the $1 \%$ level. The incremental difference between the coefficient on $R$ and the coefficient on $R \_D$ indicates that firms are engaging in accounting conservatism. The coefficient on $L C S \_R \_D(0.160)$ is positive and statistically significant at the $1 \%$ level. The incremental increase between the estimate on $R \_D$ and the estimate on $L C S \_R \_D$ indicates that firms adopt a higher level of accounting conservatism, following the conduct which gives rise to a lawsuit. This finding is consistent with model $2 \mathrm{aa}$ and supports the results obtained using Cscore as the measure of accounting conservatism. The results of the estimation of model $5 \mathrm{c}$ provide further support for the acceptance of hypothesis one.

Table 5-22 presents the estimates of model $5 \mathrm{~d}$. The results of model $5 \mathrm{~d}$ show the coefficient on $R(-0.016)$ is not statistically significant. The coefficient on $R \_D(0.089)$ is positive and statistically significant at the $1 \%$ level. The coefficient on $L F S_{-} R \_D(0.248)$ is positive and statistically significant at the $1 \%$ level. The incremental increase between the estimate on $R \_D$ and the estimate on $L F S \_R \_D$ indicates that firms are adopting a higher level of accounting conservatism, following the 
filing of a lawsuit. This finding is consistent with model $2 \mathrm{bb}$ and supports the results obtained using Cscore as the measure of accounting conservatism. The results of the estimation of model $5 \mathrm{~d}$ provide further support for the acceptance of hypothesis two. 
Table 5-19: Model 5a Regression Results

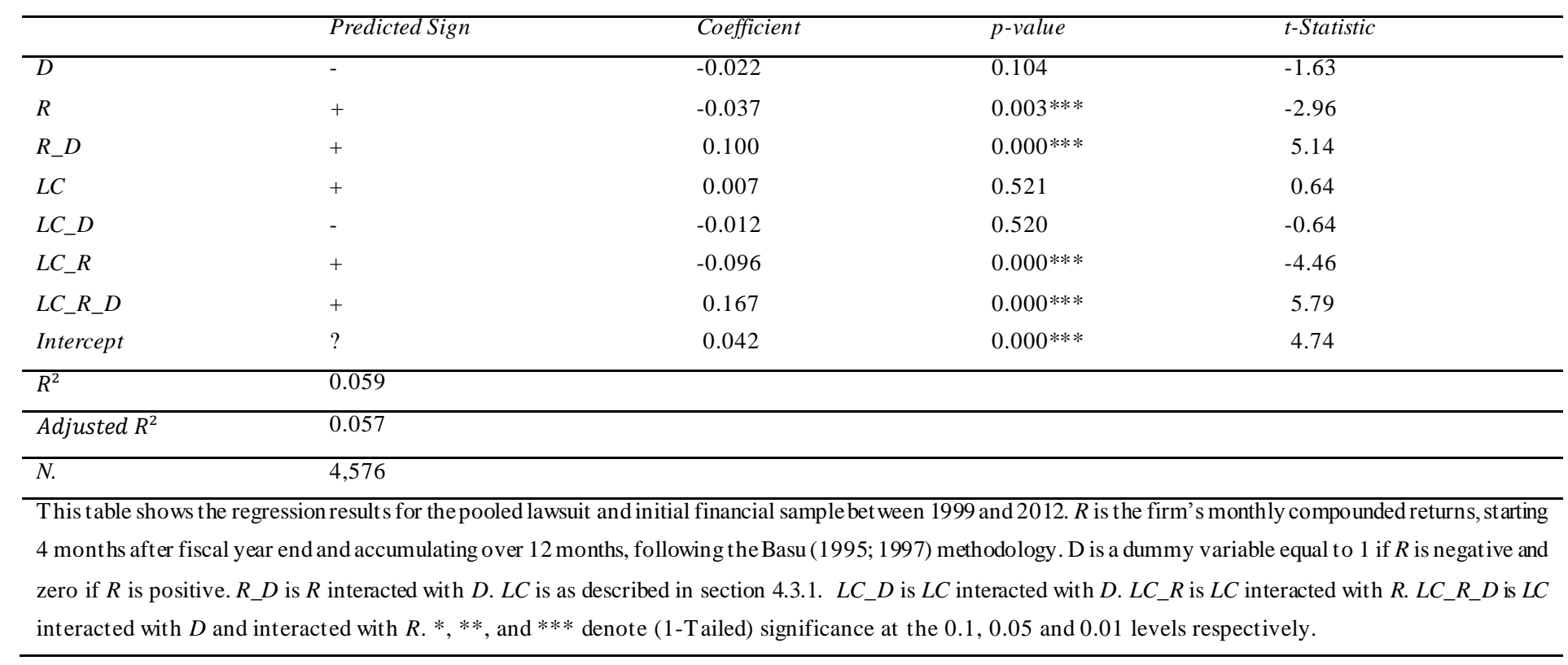


Table 5-21: Model 5c Regression Results

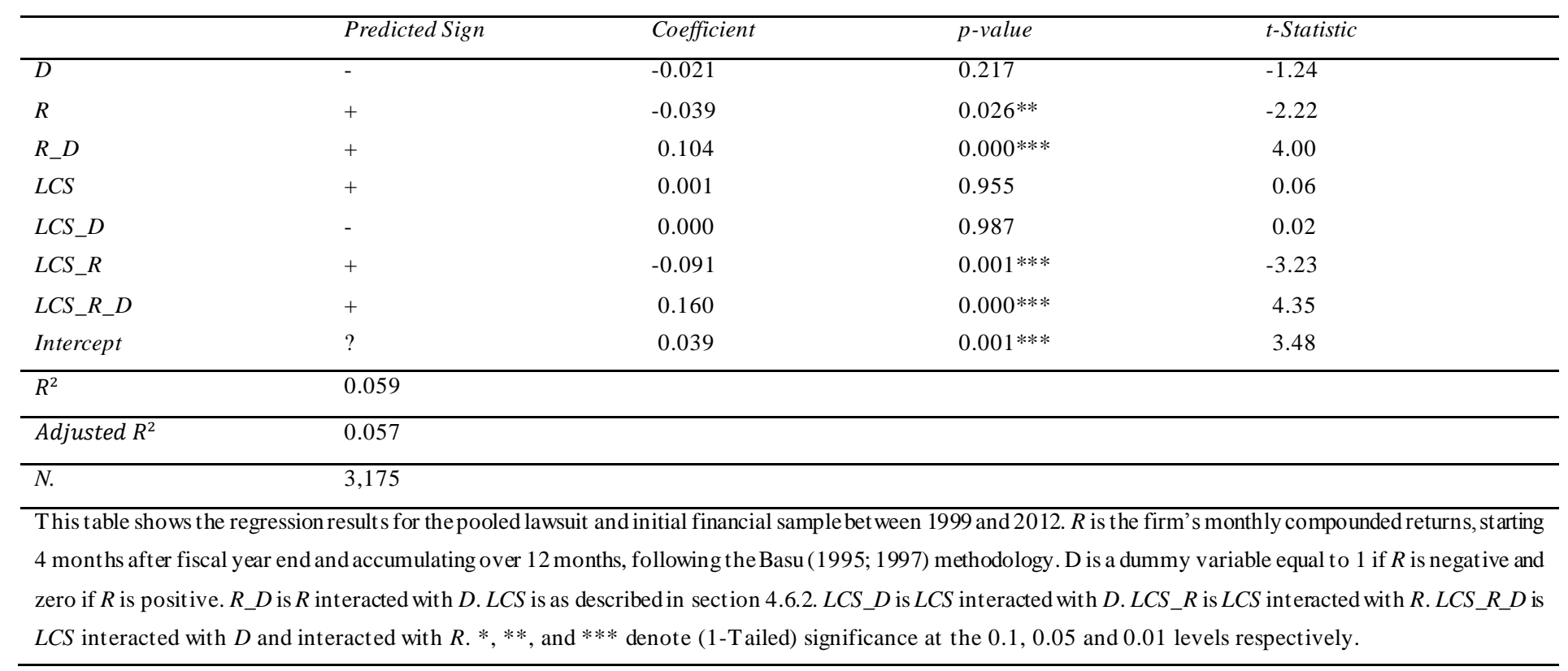


Table 5-22: Model 5d Regression Results

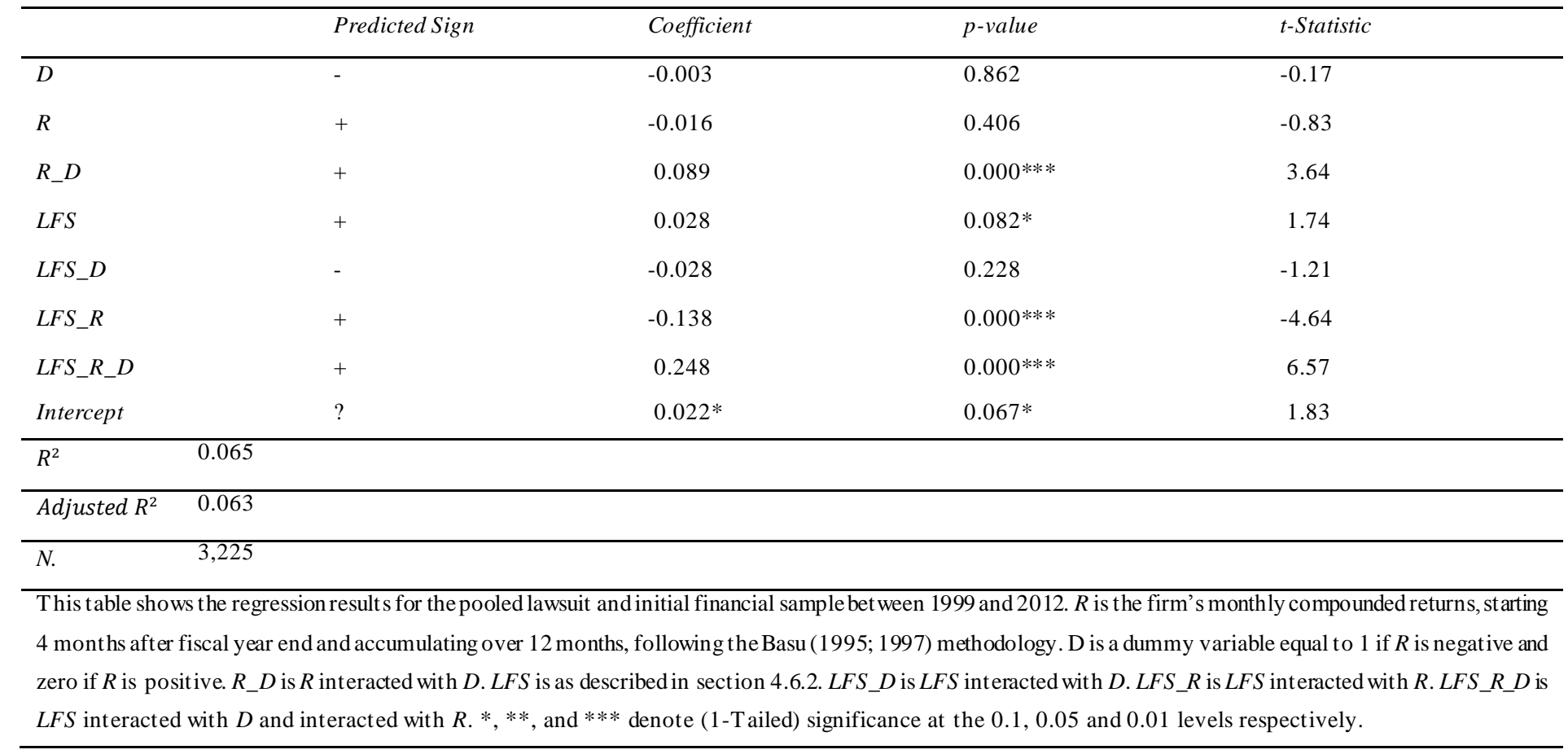


To ensure the tests of hypotheses one to four are robust to any potential selfselection bias, the Heckman two-stage procedure is employed on models $2 \mathrm{a}, 2 \mathrm{~b}, 3 \mathrm{a}$, and 3b. In Table 5-23, Table 5-24, Table 5-25, and Table 5-26. The results in Tables 5-23 to 5-26 show that the Mills Lambda is not significant ( $>.10)$ and thus selfselection bias is not a concern. 
Table 5-23: Model 2a Heckman Results

\begin{tabular}{|c|c|c|c|c|}
\hline \multicolumn{5}{|l|}{$\begin{array}{l}\text { Panel A } \\
\end{array}$} \\
\hline & Predicted Sign & Coefficient & $p$-value & Z-Statistic \\
\hline Cash_Change & + & -0.009 & .865 & -0.17 \\
\hline$L C$ & + & 0.472 & .000 & 8.77 \\
\hline Size & - & -0.086 & .000 & -5.07 \\
\hline$M B$ & + & -0.001 & .406 & -0.83 \\
\hline Lev & + & 0.268 & .026 & 2.23 \\
\hline$R V$ & + & 0.000 & .055 & 1.92 \\
\hline$C F O$ & - & -0.051 & .659 & -0.44 \\
\hline$S G$ & + & 0.000 & .665 & 0.43 \\
\hline$R D E$ & + & -0.000 & .000 & -3.92 \\
\hline$R D E \_D U M$ & $?$ & 0.001 & .663 & 2.20 \\
\hline Intercept & $?$ & 0.195 & .116 & 1.57 \\
\hline Pseudo $R^{2}$ & 0.050 & & & \\
\hline$N$. & 4,087 & & & \\
\hline \multicolumn{5}{|l|}{ Panel B } \\
\hline$L C$ & + & 0.123 & .736 & 0.34 \\
\hline $\begin{array}{l}\text { Size } \\
M B\end{array}$ & - & $\begin{array}{l}-0.033 \\
-0.037\end{array}$ & $\begin{array}{l}.638 \\
.330\end{array}$ & $\begin{array}{l}-0.47 \\
-0.97\end{array}$ \\
\hline Lev & + & -0.213 & .895 & -0.13 \\
\hline $\begin{array}{l}R V \\
C F O\end{array}$ & + & $\begin{array}{l}0.186 \\
0.000\end{array}$ & $\begin{array}{l}.922 \\
.342\end{array}$ & $\begin{array}{l}0.10 \\
0.95\end{array}$ \\
\hline$S G$ & - & 0.000 & .629 & 0.48 \\
\hline$R D E$ & + & -0.000 & .588 & -0.54 \\
\hline$R D E \_D U M$ & $?$ & 0.001 & .663 & 1.01 \\
\hline Intercept & + & -0.461 & .726 & -0.35 \\
\hline
\end{tabular}




\begin{tabular}{|c|c|c|c|c|}
\hline \multicolumn{5}{|l|}{ Select } \\
\hline Cash_Change & + & -0.009 & .865 & -0.17 \\
\hline$L C$ & + & 0.472 & .000 & 8.77 \\
\hline Size & - & -0.086 & .000 & -5.07 \\
\hline$M B$ & + & -0.002 & .406 & -0.83 \\
\hline Lev & + & 0.267 & .026 & 2.23 \\
\hline$R V$ & + & 0.000 & .055 & 1.92 \\
\hline CFO & - & -0.052 & .659 & -0.44 \\
\hline$S G$ & + & 0.000 & .665 & 0.43 \\
\hline$R D E$ & + & -0.000 & .000 & -0.39 \\
\hline$R D E \_D U M$ & $?$ & 0.021 & .534 & 0.23 \\
\hline Intercept & $?$ & 0.196 & .116 & 1.57 \\
\hline Censored observations & \multicolumn{4}{|l|}{571} \\
\hline Uncensored observations & \multicolumn{4}{|l|}{3,516} \\
\hline \multicolumn{2}{|l|}{ Mills Lambda } & 1.302 & 0.580 & 0.55 \\
\hline \multicolumn{5}{|c|}{$\begin{array}{l}\text { This table presents the regression results based on the pooled lawsuit and final financial sample from } 1999 \text { to } 2012 \text {. Cash_Change is a dummy variable equal to one if cashflow change is positive and zero if cash } \\
\text { flow change is negative. LC is as described in section } 4.3 .1 \text {. Size is the nat ural log of market value of equity. } M B \text { is the market-to-book ratio. Lev is the sum of long-term and short-term debt divided by market } \\
\text { value of equity. } R V \text { is the standard deviation of the change in revenue over the previous five years. } C F O \text { is cash flow before extraordinary items, deflated by total assets. } S G \text { is the percentage change in sales from } \\
t-1 \text { to to } . R D E \text { is research and development expense plus advertising divided by the net sales. The methodology follows Francis et al. (2004) with missing data given a value of zero. } R D E \_D U M \text { is equal to one for } \\
\text { firms which report zero } R D E \text { and zero otherwise. *, } * * \text {, and } * * * \text { denote (2-Tailed) significance at the } 0.1,0.05 \text { and } 0.01 \text { levels respectively. }\end{array}$} \\
\hline
\end{tabular}


Table 5-24: Model 2b Heckman Results

\begin{tabular}{|c|c|c|c|c|}
\hline \multicolumn{5}{|l|}{ Panel A } \\
\hline & Predicted Sign & Coefficient & $p$-value & Z-Statistic \\
\hline Cash_Change & + & 0.014 & .852 & 0.852 \\
\hline$L F$ & + & -0.078 & .005 & -0.292 \\
\hline Size & - & -0.014 & .008 & -0.49 \\
\hline$M B$ & + & -0.004 & .017 & -2.39 \\
\hline Lev & + & 0.039 & .021 & 0.23 \\
\hline$R V$ & + & 0.000 & .001 & 3.33 \\
\hline$C F O$ & - & 0.247 & .029 & 2.19 \\
\hline$S G$ & + & 0.000 & .355 & 0.20 \\
\hline$R D E$ & + & 0.000 & .355 & 0.92 \\
\hline$R D E \_D U M$ & & 0.005 & .852 & 0.20 \\
\hline Intercept & $?$ & 1.509 & .000 & 8.00 \\
\hline Pseudo $R^{2}$ & 0.053 & & & \\
\hline$N$. & 4,305 & & & \\
\hline \multicolumn{5}{|l|}{ Panel B } \\
\hline$L F$ & + & -0.013 & .863 & -0.17 \\
\hline $\begin{array}{l}\text { Size } \\
M B\end{array}$ & - & $\begin{array}{l}-0.007 \\
-0.003\end{array}$ & $\begin{array}{l}.812 \\
559\end{array}$ & $\begin{array}{r}-0.24 \\
0.58\end{array}$ \\
\hline Lev & $\begin{array}{l}+ \\
+\end{array}$ & -0.056 & .751 & -0.32 \\
\hline$R V$ & + & -4.150 & .966 & -0.04 \\
\hline$C F O$ & + & 0.211 & .240 & 1.18 \\
\hline$S G$ & - & 0.000 & .682 & 0.41 \\
\hline$R D E$ & + & -5.030 & .938 & -0.08 \\
\hline$R D E \_D U M$ & $?$ & 0.004 & .842 & 0.02 \\
\hline Intercept & + & 0.088 & .809 & 0.24 \\
\hline
\end{tabular}




\begin{tabular}{|c|c|c|c|c|}
\hline \multicolumn{5}{|l|}{ Select } \\
\hline Cash_Change & + & 0.014 & .852 & 0.19 \\
\hline$L F$ & + & -0.078 & .292 & -1.05 \\
\hline Size & - & -0.014 & .621 & -0.49 \\
\hline$M B$ & + & -0.005 & .017 & -2.39 \\
\hline Lev & + & 0.039 & .815 & 0.23 \\
\hline$R V$ & + & 0.000 & .001 & 3.33 \\
\hline CFO & - & 0.246 & .029 & 2.19 \\
\hline$S G$ & + & 0.000 & .845 & 0.20 \\
\hline$R D E$ & + & -0.000 & .355 & -0.92 \\
\hline$R D E \_D U M$ & $?$ & 0.001 & .230 & 0.05 \\
\hline Intercept & $?$ & 1.509 & .000 & 1.14 \\
\hline \multicolumn{5}{|l|}{ Censored observations } \\
\hline Uncensored observations & 4,035 & & & \\
\hline \multicolumn{2}{|l|}{ Mills Lambda } & 0.719 & 0.660 & 0.44 \\
\hline \multicolumn{5}{|c|}{$\begin{array}{l}\text { This table presents the regression results based on the pooled lawsuit and final financial sample from } 1999 \text { to } 2012 \text {. Cash_Change is a dummy variable equal to one if cashflow change is positive and zero if cash } \\
\text { flow change is negative. LC is as described in section } 4.3 .1 \text {. Size is the nat ural log of market value of equity. } M B \text { is the market-to-book ratio. Lev is the sum of long-term and short-term debt divided by market } \\
\text { value of equity. } R V \text { is the standard deviation of the change in revenue over the previous five years. } C F O \text { is cash flow before extraordinary items, deflated by total assets. } S G \text { is the percentage change in sales from } \\
t-1 \text { to to } R D E \text { is research and development expense plus advertising divided by the net sales. The methodology follows Francis et al. (2004) with missing data given a value of zero. } R D E \_D U M \text { is equal to one for } \\
\text { firms which report zero } R D E \text { and zero otherwise. } *, * * \text {, and } * * * \text { denote (2-Tailed) significance at the } 0.1,0.05 \text { and } 0.01 \text { levels respectively. }\end{array}$} \\
\hline
\end{tabular}


Table 5-25: Model 3a Heckman Results

\begin{tabular}{|c|c|c|c|c|}
\hline \multicolumn{5}{|l|}{ Panel A } \\
\hline & Predicted Sign & Coefficient & $p$-value & Z-Statistic \\
\hline Cash_Change & + & 0.017 & .845 & 0.20 \\
\hline$L C$ & + & 0.261 & .008 & 2.64 \\
\hline Size & - & -0.107 & .009 & -2.65 \\
\hline$M B$ & + & -0.069 & .002 & -3.05 \\
\hline Lev & + & -0.197 & .368 & -0.09 \\
\hline$R V$ & + & 0.000 & .006 & 2.73 \\
\hline $\mathrm{CFO}$ & - & 0.404 & .107 & 1.61 \\
\hline$S G$ & + & 8.710 & .900 & 0.13 \\
\hline$R D E$ & + & -0.000 & .002 & -3.05 \\
\hline$R D E \_D U M$ & $?$ & 0.001 & .206 & 0.26 \\
\hline$A F$ & $?$ & -2.530 & .818 & -0.23 \\
\hline$B S$ & $?$ & 0.012 & .000 & 4.20 \\
\hline$B M$ & $?$ & 0.123 & .251 & 1.15 \\
\hline$O D$ & + & 0.485 & .345 & 0.94 \\
\hline Intercept & $?$ & 0.463 & .318 & 1.00 \\
\hline Pseudo $R^{2}$ & 0.058 & & & \\
\hline$N$ & 2,204 & & & \\
\hline \multicolumn{5}{|l|}{ Panel B } \\
\hline$\overline{L C}$ & + & 0.040 & .173 & 1.36 \\
\hline $\begin{array}{l}\text { Size } \\
M B\end{array}$ & - & $\begin{array}{r}-0.001 \\
0.002\end{array}$ & $\begin{array}{l}.928 \\
.311\end{array}$ & $\begin{array}{c}-0.09 \\
1.01\end{array}$ \\
\hline Lev & + & -0.027 & .625 & -0.49 \\
\hline $\begin{array}{l}R V \\
C F O\end{array}$ & $\begin{array}{l}+ \\
+\end{array}$ & $\begin{array}{c}-3.640 \\
0.031\end{array}$ & $\begin{array}{l}.509 \\
.660\end{array}$ & $\begin{array}{r}-0.66 \\
0.44\end{array}$ \\
\hline$S G$ & - & 0.000 & .057 & 1.91 \\
\hline$R D E$ & + & -2.720 & .870 & -0.16 \\
\hline$R D E \_D U M$ & $?$ & 0.000 & .645 & 0.55 \\
\hline$A F$ & $?$ & 3.290 & .237 & 1.18 \\
\hline$B S$ & $?$ & 0.012 & .135 & 1.49 \\
\hline$B M$ & $?$ & 0.002 & .419 & 0.81 \\
\hline$O D$ & + & -0.009 & .942 & -0.07 \\
\hline Intercept & + & -0.021 & .900 & -0.13 \\
\hline
\end{tabular}




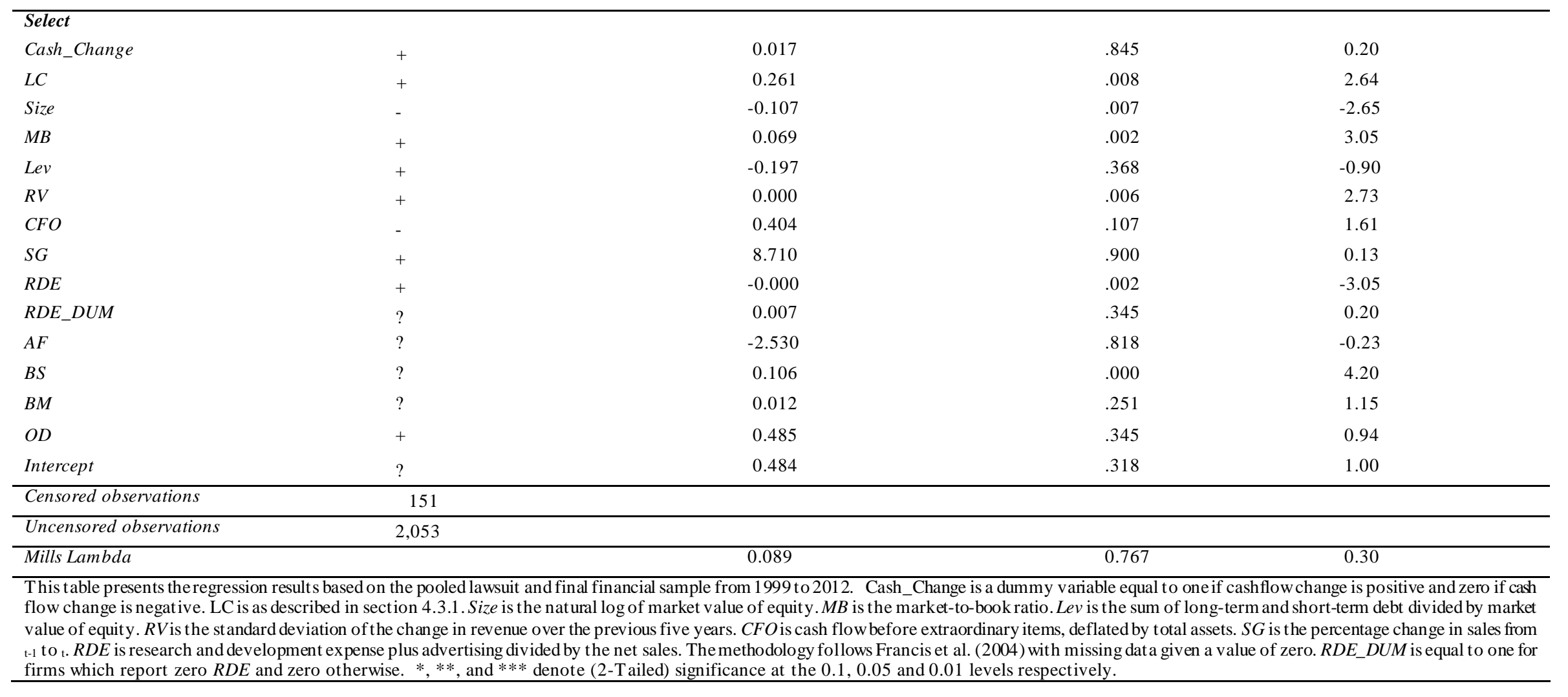


Table 5-26: Model 3b Heckman Results

\begin{tabular}{|c|c|c|c|c|}
\hline \multicolumn{5}{|l|}{ Panel A } \\
\hline & Predicted Sign & Coefficient & $p$-value & Z-Statistic \\
\hline Cash_Change & + & 0.084 & .430 & 0.79 \\
\hline$L F$ & + & -0.136 & .256 & -1.14 \\
\hline Size & - & -0.034 & .517 & -0.65 \\
\hline$M B$ & + & -0.007 & .019 & -2.34 \\
\hline Lev & + & -0.049 & .850 & -0.19 \\
\hline$R V$ & + & 0.001 & .006 & 2.72 \\
\hline CFO & - & 0.484 & .046 & 1.99 \\
\hline $\begin{array}{l}S G \\
R D E\end{array}$ & + & 0.000 & .761 & 0.30 \\
\hline & + & 0.000 & .640 & 0.47 \\
\hline$R D E \_D U M$ & $?$ & 0.051 & .552 & 0.33 \\
\hline$A F$ & $?$ & -0.000 & .223 & -1.22 \\
\hline$B S$ & $?$ & 0.005 & .855 & 0.18 \\
\hline$B M$ & $?$ & 0.012 & .313 & 1.01 \\
\hline$O D$ & + & 0.364 & .552 & 0.59 \\
\hline Intercept & $?$ & 1.510 & .009 & 2.62 \\
\hline Pseudo $R^{2}$ & 0.075 & & & \\
\hline$N$. & 2,490 & & & \\
\hline \multicolumn{5}{|l|}{ Panel B } \\
\hline$L F$ & + & 0.047 & .040 & 2.06 \\
\hline Size & - & -0.004 & .654 & -0.45 \\
\hline$M B$ & + & 0.001 & .973 & 0.03 \\
\hline Lev & + & -0.014 & .786 & -0.27 \\
\hline$R V$ & + & -4.150 & .866 & -0.17 \\
\hline CFO & + & 0.063 & .390 & 0.86 \\
\hline$S G$ & - & 0.000 & .052 & 1.94 \\
\hline$R D E$ & + & -0.000 & .383 & -0.87 \\
\hline$R D E \_D U M$ & $?$ & 0.042 & .543 & 1.37 \\
\hline$A F$ & $?$ & 4.020 & .169 & 1.44 \\
\hline$B S$ & $?$ & 0.007 & .149 & 0.32 \\
\hline$B M$ & + & 0.008 & .748 & 0.64 \\
\hline$O D$ & $?$ & 0.079 & .520 & -0.58 \\
\hline Intercept & + & -0.077 & .565 & -0.35 \\
\hline
\end{tabular}




\begin{tabular}{|c|c|c|c|c|}
\hline \multicolumn{5}{|l|}{ Select } \\
\hline Cash_Change & + & 0.084 & .430 & 0.79 \\
\hline$L F$ & + & -0.136 & .256 & -1.14 \\
\hline Size & - & -0.337 & .517 & -0.65 \\
\hline$M B$ & + & -0.007 & .019 & -2.34 \\
\hline Lev & + & -0.049 & .850 & -0.19 \\
\hline$R V$ & + & 0.001 & .006 & 2.72 \\
\hline CFO & - & 0.484 & .046 & 1.99 \\
\hline$S G$ & + & 0.000 & .761 & 0.30 \\
\hline$R D E$ & + & 0.000 & .640 & 0.47 \\
\hline$R D E \_D U M$ & $?$ & 0.002 & .223 & 0.45 \\
\hline$A F$ & $?$ & -0.000 & .432 & -1.22 \\
\hline$B S$ & $?$ & 0.005 & .855 & 0.18 \\
\hline$B M$ & $?$ & 0.012 & .313 & 1.01 \\
\hline$O D$ & + & 0.363 & .552 & 0.59 \\
\hline Intercept & $?$ & 1.51 & .009 & 2.62 \\
\hline \multicolumn{5}{|l|}{ Censored observations } \\
\hline Uncensored observations & \multicolumn{4}{|l|}{1,970} \\
\hline \multicolumn{2}{|l|}{ Mills Lambda } & 0.230 & 0.552 & 0.60 \\
\hline \multicolumn{5}{|c|}{$\begin{array}{l}\text { This table presents the regression results based on the pooled lawsuit and final financial sample from } 1999 \text { to } 2012 \text {. Cash_Change is a dummy variable equal to one if cashflow change is positive and zero if cash } \\
\text { flow change is negative. LC is as described in section } 4.3 .1 \text {. Size is the nat ural log of market value of equity. } M B \text { is the market-to-book ratio. } L e v \text { is the sum of long-term and short-term debt divided by market } \\
\text { value of equity. } R V \text { is the standard deviation of the change in revenue over the previous five years. } C F O \text { is cash flow before extraordinary items, deflated by total assets. } S G \text { is the percentage change in sales from } \\
t-1 \text { to t. } R D E \text { is research and development expense plus advertising divided by the net sales. The methodology follows Francis et al. (2004) with missing data given a value of zero. } R D E \_D U M \text { is equal to one for } \\
\text { firms which report zero } R D E \text { and zero otherwise. *,**, and } * * * \text { denote (2-Tailed) significance at the } 0.1,0.05 \text { and } 0.01 \text { levels respectively. }\end{array}$} \\
\hline
\end{tabular}




\subsubsection{Univariate Testing}

A t-test was conducted to compare the mean Cscore in pre-lawsuit and post-lawsuit years for the variables LC, LF, LCS and LFS. The results (untabulated) show that the mean Cscore for the pre-lawsuit and post-lawsuit years were significantly different at the $1 \%$ level of significance.

\subsection{Discussion of Key Findings}

The evidence as it relates to hypotheses one and two is discussed in section 5.7.1 and the evidence as it relates to hypotheses three and four is discussed in section 5.7.2. Section 5.7.3 discusses other important findings.

\subsubsection{Discussion of $\mathrm{H} 1$ and $\mathrm{H} 2$}

The results of the estimation of model $2 \mathrm{a}$ provide evidence of an association between the conduct that will go on to cause a securities lawsuit and a subsequent increase in the adoption of accounting conservatism. Specifically, the coefficient on $L C$ (0.077) in model 2a, and the coefficient on $L C S$ (0.061) in model 2aa, were both positive and statistically significant at the $1 \%$ level. These estimates provide a strong indication that the conduct that gives rise to a securities lawsuit results in a subsequent increase in the level of accounting conservatism and applies for both long and short lawsuit variable windows.

The results of the estimation of model $2 b$ provide evidence of an association between the filing of a securities lawsuit and a subsequent increase in the level of accounting conservatism. Specifically, the coefficient on $L F(0.090)$ in model 2b, and the coefficient on $\operatorname{LFS}(0.054)$ in model $2 \mathrm{bb}$, were both positive and statistically significant at the $1 \%$ level. These estimates provide a strong indication that the filing of a securities lawsuit results in a subsequent increase in the level of accounting conservatism and applies for both long and short lawsuit variable windows. 
The results of the estimation of models $2 \mathrm{a}$ and $2 \mathrm{~b}$ were also found to be robust to the use of an alternative measure of accounting conservatism, prior adoption of accounting conservatism (as tested in models $4 \mathrm{a}$ and $4 \mathrm{~b}$ ), and the use of an alternative measure of accounting conservatism (as tested in models $5 \mathrm{a}, 5 \mathrm{~b}, 5 \mathrm{c}$, and $5 \mathrm{~d})$. The totality of this evidence provides strong support for hypotheses one and two.

The finding of model $2 \mathrm{a}$ and model $2 \mathrm{~b}$ are consistent with three important theoretical mechanisms reviewed in chapter three. Firstly, that lawsuit risk is an important determinant of firm adoption of accounting conservatism (Khan and Watts, 2009; Qiang, 2007; Skinner, 1994). Secondly, that a securities lawsuit leads to an upwards re-evaluation of risk by management (Rogers and Van Buskirk, 2009). Thirdly, that firms will anticipate a securities lawsuit and take active steps to mitigate the risk and cost of the lawsuit. This finding is also consistent with (a) Blunck (2009) who found that the level of accounting conservatism affects the likelihood of being engaged in future litigation, and (b) Cheng, Huang, Li, Lobo (2010) who noted that firms anticipate future securities lawsuits and act to mitigate their negative outcomes.

Rogers and Van Buskirk (2009) reported that firms, following a securities lawsuit, reduce their market disclosures, rather than improve the quality of their disclosures. This study extends Rogers and Van Buskirk (2009) research by examining firm financial reporting rather than market disclosures. The finding of this study is that, following the conduct which gives rise to a securities lawsuit, and the filing of a securities lawsuit, firms adopt higher levels of accounting conservatism. This is consistent with Rogers and Van Buskirk (2009) in that firms are observed to change their disclosure behaviour following a securities lawsuit.

\subsubsection{Discussion of $\mathrm{H3}$ and $\mathrm{H} 4$}

This study also extends the literature by considering the moderating influence of the governance variables; $A F, B S, B M$, and $O D$ on the adoption of accounting conservatism following conduct which gives rise to a securities lawsuit, and the filing of a securities lawsuit. 
The results of the tests of hypothes is three and four are largely negative. Models $3 b$ and 3aa appear to suggest that board meetings have a moderating influence on the impact of securities lawsuits on accounting conservatism, but in each case the coefficient on the lawsuit variable is not significant. Overall, the evidence therefore leads to the rejection of hypothesis three and four.

\subsubsection{Discussion of Other Important Findings}

Examining firm financial characteristics, the findings of models 2 to 4 are partially consistent with the contracting explanation for accounting conservatism (Watts, 2003). In particular, the coefficient on Lev is consistently positive, indicating that firms with higher levels of debt are engaging in the adoption of accounting conservatism (Smith and Watts, 1992; Watts 2003).

Examining firm corporate governance, the findings of model $3 \mathrm{~b}$ are consistent with a director monitoring effort explanation for accounting conservatism (Lara et al. 2009; Vafeas, 1991). In particular, the coefficient on $B M$ is positive, indicating that directors with more frequent board meetings are better able to monitor their executive and influence the adoption of higher levels of accounting conservatis $m$. The coefficients on $B M$ in the remaining models were not statistically significant. The coefficients on the other corporate governance variables were not statistically significant in any of the models. 


\subsection{Chapter Summary}

The purpose of this chapter was to report the results of the tests of the study's hypotheses and interpret those results.

The primary tests of hypotheses one and two provides evidence towards the acceptance of hypothesis one and two. This evidence is reinforced by robustness tests which examined the past use of accounting conservatism, an alternative lawsuit measurement window, an alternative accounting conservatism measure, and self-selection bias within the sample.

Furthermore, the evidence supports Watts' (2003) expectations regarding the impact of size, market-to-book, and leverage on accounting conservatism. Overall the evidence does not support hypotheses three and four. Chapter six concludes this study. 


\section{CHAPTER SIX: CONCLUSION}

\subsection{Chapter Introduction}

This chapter concludes the study. Section 6.2 provides a summary and discussion of the study. Section 6.3 considers the contribution of the study. Section 6.4 notes the limitations of the study and discusses possible future opportunities for related research.

\subsection{Study Summary and Discussion of the Study}

Chapter one introduces the study and states that the study is primarily motivated by a gap in the existing literature concerning the influence of private securities enforcement on accounting policy choice. Specifically, the lack of prior research on the influence of disclosure-related private securities lawsuits taken under SEC rule $10 \mathrm{~b}-5$ on the level of accounting conservatism. In addition, chapter one states that the study is also motivated by the gap in the existing literature concerning the moderating influence of corporate governance on the level of accounting conservatism, following on from a securities lawsuit taken under SEC rule 10b-5. The study thus seeks to bridge these identified gaps in the literature. Chapter one also states the research questions, outlines the research methodology, the key findings, and the organization of the study.

Chapter two provides an overview of the regulation surrounding financial reporting and the US financial markets. It is clear from the US accounting framework that accounting conservatism, as an accounting policy choice, was acceptable during the period before 2010, providing that it did not undermine the reliability and integrity of financial information. In the period following 2010, it appears that the adoption of accounting conservatism should not be a primary driver in the application of accounting standards. 
The summary of the regulatory framework surrounding private securities lawsuits describes the regulatory barriers for a successful lawsuit, taken under SEC rule 10b5. Chapter two also details the number and impact of private securities lawsuits taken under SEC rule 10b-5.

Chapter three reviews the literature relevant to securities lawsuits, accounting conservatism, and corporate governance. Four important insights are identified from the literature on disclosure and accounting conservatism. First, that the content of both market disclosures and financial disclosures are associated with firm securities lawsuit risk. Second, that accounting conservatism can be adopted to mitigate contracting concerns and problems of agency. Third, that firms may preempt the impact of a potential securities lawsuit in the period before the lawsuit was filed. Fourth, that firms in the US are likely to experience a higher than average amount of change on their board and in their pool of executive officers following a securities lawsuit.

Chapter three also draws on agency theory and puts forward three theoretical mechanisms relating to the adoption of accounting conservatism following on from conduct which gives rise to a securities lawsuit, and the filing of a securities lawsuit. First, that securities lawsuit risk is subjectively evaluated by firm management and directors and thus is subject to managerial bias. Second, that when a firm is engaged in a securities lawsuit, the management and directors of that firm will be biased towards assessing securities lawsuit risk at a higher level. Third, a higher perceived lawsuit risk is expected to incentivise management and directors to adopt accounting conservatism. Thus, securities lawsuits are expected to result in the adoption of a higher level of accounting conservatism.

Drawing on these theoretical mechanisms, chapter three posits hypotheses one and two, that following the conduct that gave rise to a securities lawsuit, and the filing of a securities lawsuit, respectively, firms adopt a higher level of accounting conservatism.

Chapter three also puts forward four theoretical mechanisms relating to corporate governance and the moderation of accounting conservatism, following the conduct 
that gives rise to a lawsuit, and the filing of a securities lawsuit. First, audit cost is linked to audit lawsuit risk, with lower audit costs linked to higher levels of accounting conservatism. Second, board size is associated with the total amount of resources available to the board, with a larger board better able to influence the greater adoption of accounting conservatism. Third, board meetings are also associated with the level of resources available to the board, with more board meetings enabling the board to influence the adoption of a higher level of accounting conservatism. Fourth, more independent boards have a greater incentive to lower information asymmetry between the firm and its investors and are likely to adopt a higher level of accounting conservatism to achieve this. Thus chapter three also posits hypotheses three and four: corporate governance, as measured by (a) audit fees, (b) board size, (c) number of board meetings, and (d) the percentage of outside directors, moderates the relationship between the conduct that gives rise to a securities lawsuit, and the filing of a securities lawsuit, respectively, and firm adoption of a higher level of accounting conservatis $m$.

Chapter four sets out the methodology used to test the hypotheses, and defines the variables and sample used in the study. Chapter four also describes the measures for the securities lawsuit events, the measures of accounting conservatism and defines four corporate governance variables that are used in this study; $A F, B S, B M$, and $O D$.

Chapter five presents the results of the tests of the hypotheses and interprets these results. This study finds evidence in support of hypotheses one and two but in totality no support for hypotheses three and four. These findings indicate that disclosure-related securities lawsuits, taken under SEC rule 10b-5, influence accounting policy choice and in particular, the decision to adopt accounting conservatism. Furthermore, the results provide support for size, market-to-book and leverage as determinants of accounting conservatism, as identified by Khan and Watts (2009). 


\subsection{Contribution}

The findings of this study provide multiple contributions to the academic literature specifically on private disclosure-related securities lawsuits taken under SEC rule 10b-5, accounting conservatism, and corporate governance. In particular, this study makes two key contributions that will be of interest to academics, regulators, investors, standard setters, auditors and company directors.

First, using a unique hand collected sample, this study finds evidence of a positive link between disclosure-related private securities lawsuits and the adoption of accounting conservatism. This finding adds to the body of knowledge concerning the impact of private securities lawsuits and suggests to policy makers that the adoption of a private securities lawsuit regime may result in the greater adoption of accounting conservatism by sued firms. This finding may also be of value to investors and fund managers trading in the US share market. In particular, investors and fund managers may be able to utilize this research to more accurately anticipate the direction of changes in the quality of the reported earnings of firms subject to a securities lawsuit in the US. This finding also provides strong evidence in support of Watts' (2003) theorized link between information asymmetry and the adoption of accounting conservatism.

Second, this study finds no convincing evidence that audit fees, board size, board meetings, and the percentage of outside directors moderate the influence of securities lawsuits on the level of accounting conservatism.

\subsection{Limitations and direction for future research}

Three primary limitations of this study are identified. These limitations relate to the methodology and scope of the research.

Firstly, the lawsuit variables used in this study examine each firm subject to a securities lawsuit for up to thirteen firm-years. This methodology allows for the examination of long-term firm response to a lawsuit event. However, this period is vulnerable to the effects of unrelated changes to internal governance, financial 
characteristics, or external economic factors. Additionally, for a sued firm to be represented in the sample, the firm must have been publicly listed. This study sought to control for these issues by controlling for firm financial and governance characteristics, as well as through the use of a series of robustness tests.

Second, data on the governance variables was not available for the period 1999 to 2001. As a result, no conclusions can be drawn regarding the influence of governance on the link between disclosure-related securities lawsuits and accounting conservatism during that period.

Third, this study only examines private securities lawsuits within the US. The US jurisdiction is a high litigation environment with a unique regulatory structure. As such, it may be questionable to generalize the findings of this study from the US across to other regulatory jurisdictions or apply the findings to the public enforcement of securities law.

Turning to future directions for research, while noting the difference in regulatory environments, the link between disclosure-related securities lawsuits and the adoption of accounting conservatism could be explored in low litigation risk environments such as New Zealand and Australia. Research in this area would help determine whether firms also respond to disclosure-related securities lawsuits in low litigation risk environments with the increased adoption of accounting conservatism.

Research could also be completed to examine the role of corporate governance in moderating the adoption of accounting conservatism in more detail. The variables used in this study may not proxy well for the resource capabilities and independence of the board. Research that uses more precise proxies for governance ability would allow more generalizable conclusions on how board capability moderates firm behavior. Additionally, further research could also examine whether corporate governance mechanisms act independently or work together to influence firm choice of the level of accounting conservatism.

Previous research has documented that, within the US following a securities 
lawsuit, market disclosures are reduced (Rogers and Van Buskirk, 2009). This reduction in disclosures is caused by firms seeking to lower their securities lawsuit risk (Rogers and Van Buskirk, 2009). Further research could investigate if, following conduct which gives rise to a securities lawsuit, and the filing of a securities lawsuit, there is any interaction or substitution between the adoption of a higher level of accounting conservatism and a reduction in market disclosures. 


\section{REFERENCES}

Abbott, L. J., Parker, S., Peters, G. F., \& Raghunandan, K. (2003). The association between audit committee characteristics and audit fees. Auditing: A Journal of Practice \& Theory, 22(2), 17-32.

Agrawal, A., \& Cooper, T. (2017). Corporate governance consequences of accounting scandals: Evidence from top management, CFO and auditor turnover. Quarterly Journal of Finance, 7(1), 1-41.

Agrawal, A., Jaffe, J. F., \& Karpoff, J. M. (1999). Management turnover and governance changes following the revelation of fraud. The Journal of Law and Economics, 42(2), 309-342.

Ahmed, A., Billings, B., Morton, R., \& Stanford-Harris, M. (2002). The role of accounting conservatism in mitigating bondholder-shareholder conflicts over dividend policy and in reducing debt costs. The Accounting Review, 77(4), 867-890.

Ahmed, A. S., \& Duellman, S. (2007). Accounting conservatism and board of director characteristics: An empirical analysis. Journal of Accounting and Economics, 43(2-3), 411-437.

Ahmed, K., \& Henry, D. (2012). Accounting conservatism and voluntary corporate governance mechanisms by Australian firms. Accounting \& Finance, 52(3), 631-662.

Akerlof, G. A. (1970). The Market for" Lemons": Quality Uncertainty and the Market Mechanism. The Quarterly Journal of Economics, 84(3), 488-500.

Alexander, J. C. (1991). Do the merits matter? A study of settlements in securities class actions. Stanford Law Review, 43(3), 497-598. 
Alexander, J. C. (1996). Rethinking damages in securities class actions. Stanford Law Review, 48(6), 1487-1537.

Amoah, N. Y., \& Tang, A. P. (2013). Resolution of restatement-induced lawsuits after the Private Securities Litigation Reform Act. Research in Accounting Regulation, 25(1), 41-46.

Arlen, J. H., \& Carney, W. J. (1992). Vicarious liability for fraud on securities markets: Theory and evidence. The University of Illinois Law Review, 691740.

Baginski, S. P., Hassell, J. M., \& Kimbrough, M. D. (2002). The effect of legal environment on voluntary disclosure: Evidence from management earnings forecasts issued in US and Canadian markets. The Accounting Review, 77(1), 25-50.

Baker, T., \& Griffith, S. J. (2008). How the merits matter: directors' and officers' insurance and securities settlements. University of Pennsylvania Law Review, 157(3), 755-832.

Ball, R., Kothari, S., \& Robin, A. (2000). The effect of international institutional factors on properties of accounting earnings. Journal of Accounting and Economics, 29(1), 1-51.

Ball, R., \& Shivakumar, L. (2005). Earnings quality in UK private firms: comparative loss recognition timeliness. Journal of Accounting and Economics, 39(1), 83-128.

Basic Inc. v. Levinson. 485 U.S. 224 (1988).

Basu, S. (1997). The conservatism principle and the asymmetric timeliness of earnings1. Journal of Accounting and Economics, 24(1), 3-37. 
Basu, S. (1995). Conservatism and the Asymmetric Timeliness of Earning, Ph.D. thesis, University of. Rochester.

Baum, C. F., Bohn, J. G., \& Chakraborty, A. (2016). Securities fraud and corporate board turnover: New evidence from lawsuit outcomes. International Review of Law and Economics, 48(C), 14-25.

Beatty, A., Weber, J., \& Yu, J. J. (2008). Conservatism and debt. Journal of Accounting and Economics, 45(2-3), 154-174.

Beaver, W. H., \& Ryan, S. G. (2005). Conditional and unconditional conservatis m: Concepts and modeling. Review of Accounting Studies, 10(2-3), 269-309.

Beck, J. D., \& Bhagat, S. (1997). Shareholder litigation: Share price movements, news releases, and settlement amounts. Managerial and Decision Economics, 18(7/8), 563-586.

Beekes, W., Pope, P., \& Young, S. (2004). The link between earnings timeliness, earnings conservatism and board composition: evidence from the UK. Corporate Governance: An International Review, 12(1), 47-59.

Bliss, J. H. (1924). Management through accounts. New York: Ronald Press Company.

Blunck, R. K. (2009). Does more conservative accounting reduce litigation costs? : Working paper, The University of Iowa.

Brown, S., Hillegeist, S. A., \& Lo, K. (2005). Management forecasts and litigation risk: Working paper: Emory University, Northwestern University, and University of British Columbia.

Bushman, R., Chen, Q., Engel, E., \& Smith, A. (2004). Financial accounting information, organizational complexity and corporate governance systems. Journal of Accounting and Economics, 37(2), 167-201. 
Bushman, R. M., \& Piotroski, J. D. (2006). Financial reporting incentives for conservative accounting: The influence of legal and political institutions. Journal of Accounting and Economics, 42(1-2), 107-148.

Cao, Z., \& Narayanamoorthy, G. S. (2011). The effect of litigation risk on management earnings forecasts. Contemporary Accounting Research, 28(1), 125-173.

Carcello, J. V., Hermanson, D. R., Neal, T. L., \& Riley, R. A. (2002). Board characteristics and audit fees. Contemporary Accounting Research, 19(3), 365-384.

Chalmers, K., Naiker, V., \& Navissi, F. (2012). Earnings quality and Rule 10b-5 securities class action lawsuits. Journal of Accounting and Public Policy, $31(1), 22-43$.

Chen, G., Firth, M., Gao, D. N., \& Rui, O. M. (2006). Ownership structure, corporate governance, and fraud: Evidence from China. Journal of Corporate Finance, 12(3), 424-448.

Cheng, C. A., Huang, H. H., Li, Y., \& Lobo, G. (2010). Institutional monitoring through shareholder litigation. Journal of Financial Economics, 95(3), 356383.

Choi, S. J. (2004). The evidence on securities class actions. Vanderbilt Law Review, 57(5), 1465-1526.

Coase, R. H. (1937). The nature of the firm. Economica, 4(16), 386-405.

Coffee, J. C. (2006). Reforming the securities class action: An essay on deterrence and its implementation. Columbia Law Review, 106(7), 1534-1586. 
Cornerstone Research. (2006). Securities Class Action Filings 2006: A Year In Review. Cornerstone Research. Retrived from http://securities.stanford.edu/research-reports/1996-2006/CornerstoneResearch-Securities-Class-Action-Filings-2006-YIR.pdf.

Cox, J. D. (1997). Making securities fraud class actions virtuous. Arizona Law Review, 39(2), 497-524.

Cox, J. D., \& Thomas, R. S. (2006). Does the Plaintiff Matter-An Empirical Analysis of Lead Plaintiffs in Securities Class Actions. Columbia Law Review, 106(7), 1587-1640.

Dechow, P. M., \& Dichev, I. D. (2002). The quality of accruals and earnings: The role of accrual estimation errors. The Accounting Review, 77(1), 35-59.

DeFond, M. L., Lim, C. Y., \& Zang, Y. (2015). Client conservatism and auditorclient contracting. The Accounting Review, 91(1), 69-98.

Diamond, D. W., \& Verrecchia, R. E. (1991). Disclosure, liquidity, and the cost of capital. The Journal of Finance, 46(4), 1325-1359.

Dietrich, J. R., Muller, K. A., \& Riedl, E. J. (2007). Asymmetric timeliness tests of accounting conservatism. Review of Accounting Studies, 12(1), 95-124.

Donelson, D. C., McInnis, J. M., Mergenthaler, R. D., \& Yu, Y. (2012). The timeliness of bad earnings news and litigation risk. The Accounting Review, 87(6), 1967-1991.

Dura Pharmaceuticals, Inc. v. Broudo. 544 U.S. 336 (2005).

Dyl, E. A. (1999). Estimating economic damages in class action securities fraud litigation. Journal of Forensic Economics, 12(1), 1-11. 
Easley, D., Hvidkjaer, S., \& O'Hara, M. (2002). Is information risk a determinant of asset returns? The Journal of Finance, 57(5), 2185-2221.

Easton, P., \& Pae, J. (2004). Accounting conservatism and the relation between returns and accounting data. Review of Accounting Studies, 9(4), 495-521.

Eisenberg, T., \& Lanvers, C. (2009). What is the settlement rate and why should we care? Journal of Empirical Legal Studies, 6(1), 111-146.

Ellen, M. \& Laura E. S. (2012). Securities Class Action Filings 2012: A Year in Review. Retrived from http://www.cornerstone.com/Publications/Reports/ Securities-Class-Action-Settlements-2012-YIR.

Ettredge, M. L., Huang, Y., \& Zhang, W. (2015). Conservative reporting and securities class action lawsuits. Accounting Horizons, 30(1), 93-118.

Fich, E. M., \& Shivdasani, A. (2007). Financial fraud, director reputation, and shareholder wealth. Journal of Financial Economics, 86(2), 306-336.

Field, L., Lowry, M., \& Shu, S. (2005). Does disclosure deter or trigger litigation? Journal of Accounting and Economics, 39(3), 487-507.

Financial Accounting Standard Board (2010). Conceptual Framework of Financial Reporting; Statement of Financial Accounting Concepts No. 8, Norwalk: CT: FASB.

Financial Accounting Standards Board (1980). Qualitative Characteristics of Accounting Information; Statement of Financial Accounting Concepts No. 2, Norwalk CT: FASB.

Francis, J., LaFond, R., Olsson, P. M., \& Schipper, K. (2004). Costs of equity and earnings attributes. The Accounting Review, 79(4), 967-1010. 
Francis, J., Philbrick, D., \& Schipper, K. (1994). Shareholder litigation and corporate disclosures. Journal of Accounting Research, 32(2), 137-164.

Gao, Y., Kim, J. B., Tsang, D., \& Wu, H. (2017). Go before the whistle blows: an empirical analysis of director turnover and financial fraud. Review of Accounting Studies, 22(1), 320-360.

Ge, W., \& McVay, S. (2005). The disclosure of material weaknesses in internal control after the Sarbanes-Oxley Act. Accounting Horizons, 19(3), 137-158.

Gillan, S. L. (2006). Recent developments in corporate governance: an overview. Journal of Corporate Finance, 12(3), 381-402.

Gillan, S. L., \& Panasian, C. A. (2014). On Litigation Risk and Disclosure Complexity: Evidence from Canadian Firms Cross-Listed in the US. The International Journal of Accounting, 49(4), 426-454.

Givoly, D., Hayn, C. K., \& Natarajan, A. (2007). Measuring reporting conservatism. The Accounting Review, 82(1), 65-106.

Gompers, P., Ishii, J., \& Metrick, A. (2003). Corporate governance and equity prices. The Quarterly Journal of Economics, 118(1), 107-156.

Grundfest, J. A., \& Perino, M. A. (1997). Securities litigation reform: The first year's experience. Working paper, Stanford University.

Gul, F. A., Srinidhi, B., \& Shieh, T. (2004). The Asian financial crisis, accounting conservatism and audit fees: Evidence from Hong Kong: Working paper, City University of Hong Kong.

Habib, A., Jiang, H., Bhuiyan, M. B. U., \& Islam, A. (2014). Litigation risk, financial reporting and auditing: A survey of the literature. Research in Accounting Regulation, 26(2), 145-163. 
Healy, P. M. (1985). The effect of bonus schemes on accounting decisions. Journal of Accounting and Economics, 7(1-3), 85-107.

Heckman, J. J. (1979). Statistical models for discrete panel data. Chicago, IL: Department of Economics and Graduate School of Business, University of Chicago.

Helland, E., \& Sykuta, M. (2005). Who's monitoring the monitor? Do outside directors protect shareholders' interests? Financial Review, 40(2), 155-172.

Hermalin, B. E., \& Weisbach, M. S. (2003). Boards of directors as an endogenously: A Survey of the Economic Literature. Working Paper, National Bureau of Economic Research, Cambridge, Massachusetts. Retrieved from http//www.nber.org/papers/w8161

Jackson, H. E. (2007). Variation in the intensity of financial regulation: Preliminary evidence and potential implications. Yale Journal on Regulation, 24(2), 253-292.

Jenkins, D. S., \& Velury, U. (2008). Does auditor tenure influence the reporting of conservative earnings? Journal of Accounting and Public Policy, 27(2), 115-132.

Jensen, M. C., \& Meckling, W. H. (1976). Theory of the firm: Managerial behavior, agency costs and ownership structure. Journal of Financial Economics, 3(4), 305-360.

Johnson, M. F., Kasznik, R., \& Nelson, K. K. (2001). The impact of securities litigation reform on the disclosure of Forward-Looking information by high technology firms. Journal of Accounting research, 39(2), 297-327.

Jones, C., \& Weingram, S. (1996). The determinants of 10b-5 litigation risk: Working paper, Stanford University. 
Khan, M., \& Watts, R. L. (2009). Estimation and empirical properties of a firmyear measure of accounting conservatism. Journal of Accounting and Economics, 48(2), 132-150.

Kim, I., \& Skinner, D. J. (2012). Measuring securities litigation risk. Journal of Accounting and Economics, 53(1-2), 290-310.

Kim, O., \& Verrecchia, R. E. (1991). Trading volume and price reactions to public announcements. Journal of Accounting Research, 29(2), 302-321.

Kinney Jr, W. R., \& McDaniel, L. S. (1989). Characteristics of firms correcting previously reported quarterly earnings. Journal of Accounting and Economics, 11(1), 71-93.

Klein, A. (2002). Audit committee, board of director characteristics, and earnings management. Journal of Accounting and Economics, 33(3), 375-400.

Kothari, S. P., Shu, S., \& Wysocki, P. D. (2009). Do Managers Withhold Bad News? Journal of Accounting Research, 47(1), 241-276.

LaFond, R., \& Watts, R. L. (2008). The information role of conservatism. The Accounting Review, 83(2), 447-478.

Langevoort, D. C. (1996). Capping Damages for Open-Market Securities Fraud. Arizona Law Review, 38(2), 639-664.

Lara, J. M. G., Osma, B. G., \& Penalva, F. (2009). Accounting conservatism and corporate governance. Review of Accounting Studies, 14(1), 161-201.

Larcker, D., Richardson, S., \& Tuna, I. (2007). Corporate governance, accounting outcomes, and organizational performance. Accounting Review, 82(4), 9631008 . 
Lee, H. S., Li, X., \& Sami, H. (2014). Conditional conservatism and audit fees. Accounting Horizons, 29(1), 83-113.

Leuz, C., \& Verrecchia, R. E. (2000). The economic consequences of increased disclosure. Journal of Accounting Research, 38, 91-124.

Lim, R. (2011). Are corporate governance attributes associated with accounting conservatism? Accounting \& Finance, 51(4), 1007-1030.

Liu, Z. F., Thornton, D. B., \& Elayan, F. A. (2013). Litigation cost, market-to-book, and asymmetric timeliness of earnings. International Journal of Finance and Accounting Studies, 1(1), 1-17.

Malkiel, B. G., \& Fama, E. F. (1970). Efficient capital markets: A review of theory and empirical work. The Journal of Finance, 25(2), 383-417.

Martin, D. N., Juneja, V. M., Foster, T. S., \& Dunbar, F. C. (1999). Recent trends IV: What explains filings and settlements in shareholder class actions. Stanford Journal of Law, Business \& Finance, 5(1), 121-174.

McNichols, M. (1988). A comparison of the skewness of stock return distributions at earnings and non-earnings announcement dates. Journal of Accounting and Economics, 10(3), 239-273.

McShane, B. B., Watson, O. P., Baker, T., \& Griffith, S. J. (2012). Predicting securities fraud settlements and amounts: a hierarchical Bayesian model of federal securities class action lawsuits. Journal of Empirical Legal Studies, 9(3), 482-510.

McTier, B. C., \& Wald, J. K. (2011). The causes and consequences of securities class action litigation. Journal of Corporate Finance, 17(3), 649-665.

Mishkin, F. S. (2011). Over the cliff: From the subprime to the global financial crisis. Journal of Economic Perspectives, 25(1), 49-70. 
Mueller, G. G. (1964). Valuing Inventories at Other Than Historical Costs-Some International Differences. Journal of Accounting Research, 2(2), 148-157.

Niehaus, G., \& Roth, G. (1999). Insider trading, equity issues, and CEO turnover in firms subject to securities class action. Financial Management, 28(4), 5272.

Persons, O. S. (2006). The effects of fraud and lawsuit revelation on US executive turnover and compensation. Journal of Business Ethics, 64(4), 405-419.

Private Securities Reform Act 1995, 15 U.S.C (1995)

Qiang, X. (2007). The effects of contracting, litigation, regulation, and tax costs on conditional and unconditional conservatism: Cross-sectional evidence at the firm level. The Accounting Review, 82(3), 759-796.

Rogers, J. L., \& Van Buskirk, A. (2009). Shareholder litigation and changes in disclosure behavior. Journal of Accounting and Economics, 47(1), 136-156.

Rogers, J. L., Van Buskirk, A., \& Zechman, S. L. (2011). Disclosure tone and shareholder litigation. The Accounting Review, 86(6), 2155-2183.

Romano, R. (1991). The shareholder suit: litigation without foundation? Journal of Law, Economics, \& Organization, 7(1), 55-87.

Rose, A. M. (2008). Reforming Securities Litigation Reform: Restructuring the Relationship Between Public and Private Enforcement of Rule 10b-5. Columbia Law Review, 108(6), 1301-1364.

Roychowdhury, S., \& Watts, R. L. (2007). Asymmetric timeliness of earnings, market-to-book and conservatism in financial reporting. Journal of Accounting and Economics, 44(1-2), 2-31. 
Ryan, S. G. (2006). Identifying conditional conservatism. European Accounting Review, 15(4), 511-525.

Securities and Exchange Commission v. Texas Gulf Sulphur Co. 394 U.S. 976 (1969).

Securities and Exchange Act 1934, 15 U.S.C (1934).

Securities and Exchange Act 1934, 15 U.S.C Sec. 240.10b-5 (1934).

Seetharaman, A., Gul, F. A., \& Lynn, S. G. (2002). Litigation risk and audit fees: Evidence from UK firms cross-listed on US markets. Journal of Accounting and Economics, 33(1), 91-115.

Seligman, J. (1994). The Merits Do Matter: A Comment on Professor Grundfest's" Disimplying Private Rights of Action Under the Federal Securities Laws: The Commission's Authority". Harvard Law Review, 108(2), 438-457.

Skinner, D. J. (1994). Why firms voluntarily disclose bad news. Journal of Accounting Research, 32(1), 38-60.

Skinner, D. J. (1997). Earnings disclosures and stockholder lawsuits. Journal of Accounting and Economics, 23(3), 249-282.

Smith, C. W., \& Watts, R. L. (1992). The investment opportunity set and corporate financing, dividend, and compensation policies. Journal of Financial Economics, 32(3), 263-292.

Srinivasan, S. (2005). Consequences of financial reporting failure for outside directors: Evidence from accounting restatements and audit committee members. Journal of Accounting Research, 43(2), 291-334.

Sterling, R. R. (1967). Conservatism: The fundamental principle of valuation in traditional accounting. Abacus, 3(2), 109-132. 
Strahan, P. (1998). Securities class actions, corporate governance and managerial agency problems (No. 9816). Federal Reserve Bank of New York.

Tellabs, Inc. v. Makor Issues \& Rights, Ltd. 551 U.S. 308 (2007).

Tucker, J. W. (2010). Selection Bias and Econometric Remedies in Accounting and Finance Research. Journal of Accounting Literature, 29(1), 31-57.

United States Supreme Court (1975). Federal Rules of Civil Procedure, as Amended Through July 1, 1975. Foundation Press.

Uzun, H., Szewczyk, S. H., \& Varma, R. (2004). Board Composition and Corporate Fraud. Financial Analysts Journal, 60(3), 33-43.

Vafeas, N. (1999). Board meeting frequency and firm performance. Journal of Financial Economics, 53(1), 113-142.

Watts, R. L. (2003). Conservatism in accounting part I: Explanations and implications. Accounting Horizons, 17(3), 207-221.

Watts, R. L., \& Zimmerman, J. L. (1978). Towards a positive theory of the determination of accounting standards. Accounting Review, 53(1), 112-134.

Wittenberg-Moerman, R. (2008). The role of information asymmetry and financial reporting quality in debt trading: Evidence from the secondary loan market. Journal of Accounting and Economics, 46(2), 240-260.

Wollscheid, C. (2012). Rise and Burst of the Dotcom Bubble: Causes, Characteristics, Examples. Munich: Verlag.

Xie, B., Davidson III, W. N., \& DaDalt, P. J. (2003). Earnings management and corporate governance: the role of the board and the audit committee. Journal of Corporate Finance, 9(3), 295-316. 
Yamfo Amoah, N. (2013). Legal penalty for fraud and CEO turnover. Journal of Accounting \& Organizational Change, 9(3), 322-335.

Yatim, P., Kent, P., \& Clarkson, P. (2006). Governance structures, ethnicity, and audit fees of Malaysian listed firms. Managerial Auditing Journal, 21(7), 757-782.

Yermack, D,. (1996). Higher market valuation of companies with a small boards of directors. Journal of Financial Economics, 40(2), 185-211. 


\section{APPENDIX ONE: VARIABLE DEFINITIONS}

\begin{tabular}{|c|c|}
\hline Variable & Variable Definition \\
\hline \multicolumn{2}{|r|}{ Panel A: Dependent Variables } \\
\hline Cscore & $\begin{array}{l}\text { Measures conditional accounting conservatism, following the Khan and Watts (2009) methodology, } \\
\text { as defined in section 4.2. }\end{array}$ \\
\hline $\bar{X}$ & Net income before extraordinary items, scaled by lagged market value of equity. \\
\hline \multicolumn{2}{|r|}{ Panel B: Independent Variables - Lawsuit } \\
\hline$L C$ & $\begin{array}{l}\text { LC is a variable with a value of one in the financial year lawsuit conduct started. The six financial } \\
\text { years subsequent to the start of the lawsuit conduct are also given a value of one. The six financial } \\
\text { years preceding the start of the lawsuit conduct are given a value of zero. In order for a potential } \\
\text { change in accounting conservatism to be reflected in the financial statements, if the start of the lawsuit } \\
\text { conduct took place in the last six months of a given financial year, the lawsuit conduct is recorded as } \\
\text { having taken place in the following financial year. }\end{array}$ \\
\hline$L F$ & $\begin{array}{l}\text { LF is a variable with a value of one in the financial year in which the lawsuit filing occurred. The six } \\
\text { financial years following the lawsuit filing are also given a value of one. The six financial years } \\
\text { preceding the lawsuit filing are given a value of zero. In order for a potential change in accounting } \\
\text { conservatism to be reflected in the financial statements, if the lawsuit filing took place in the last six } \\
\text { months of a given financial year, the lawsuit filing is recorded as having taken place in the following } \\
\text { financial year. }\end{array}$ \\
\hline$\overline{L C S}$ & $\begin{array}{l}\text { LCS is equal to one in the financial year the lawsuit conduct started. For the three financial years } \\
\text { following the start of the conduct, LCS is also equal to one. The three financial years preceding the } \\
\text { start of the lawsuit conduct are given a value of zero. In order for a potential change in accounting } \\
\text { conservatism to be reflected in the financial statements, if the lawsuit conduct started in the last six } \\
\text { months of a given financial year, the lawsuit conduct is recorded as taking place in the following } \\
\text { financial year. }\end{array}$ \\
\hline LFS & $\begin{array}{l}\text { LFS is a variable with a value of } 1 \text { in the financial year in which the lawsuit filing occurred. The } \\
\text { subsequent three financial years following the lawsuit filing are given a value of one. The three } \\
\text { financial years preceding the lawsuit filing are given a value of zero. In order for a potential change in } \\
\text { accounting conservatism to be reflected in the financial statements, where the lawsuit filing occurred } \\
\text { in the last six months of a given financial year, the lawsuit filing is recorded as taking place in the } \\
\text { following financialyear. }\end{array}$ \\
\hline \multicolumn{2}{|r|}{ Panel C: Independent Variables- Financial } \\
\hline$R$ & $\begin{array}{l}\text { The firm's monthly compounded returns, starting } 4 \text { months after fiscal year end and accumulating } \\
\text { over } 12 \text { months, following the Basu }(1995 ; 1997) \text { methodology. }\end{array}$ \\
\hline$D$ & Dummy variable equal to 1 if $R$ is negative and zero if $R$ is positive. \\
\hline Size & The natural log of market value of equity. \\
\hline$M B$ & The market-to-book ratio. \\
\hline Lev & The sum of long-term and short-term debt divided by market value of equity. \\
\hline$R \_$Size & $R$ interacted with Size. \\
\hline
\end{tabular}




\begin{tabular}{|c|c|}
\hline$R \_M B$ & $R$ interacted with the $M B$. \\
\hline R_Lev & $R$ interacted with $L e v$. \\
\hline$R \_D$ & $R$ interacted with $D$. \\
\hline $\bar{D} \_M B$ & $D$ interacted with $M B$. \\
\hline D_Lev & $D$ interacted with $L e v$. \\
\hline$R \_D \_S i z e$ & $R$ interacted with $D$ and interacted with Size. \\
\hline$R \_D \_M B$ & $R$ interacted with $D$ and interacted with $M B$. \\
\hline$R \_D \_L e v$ & $R$ interacted with $D$ and interacted with $L e v$. \\
\hline D_Size & $D$ interacted with Size. \\
\hline$R V$ & The st andard deviation of the change in revenue over the previous five years. \\
\hline $\mathrm{CFO}$ & Cash flow before extraordinary items, deflated by total assets. \\
\hline$S G$ & The percentage change in sales from $t_{t-1} t_{t}$. \\
\hline$R D E$ & $\begin{array}{l}\text { Research and development expense plus advertising divided by the net sales. Missing values of } \\
\text { research and development and advertising are set to zero. }\end{array}$ \\
\hline$R D E \_D U M$ & Equal to one for firms which report zero $R D E$ and zero otherwise. \\
\hline Cash_Change & $\begin{array}{l}\text { A dummy variable equal to one if cash flow change is positive and zero if cash flow change is } \\
\text { negative. }\end{array}$ \\
\hline Cscore $_{(t-1)}$ & Firm-year conservatism (Cscore) lagged by one year. \\
\hline$L C \_R$ & $L C$ interacted with $R$. \\
\hline$L C \_D$ & $L C$ interacted with $D$. \\
\hline$L C \_R \_D$ & $L C$ interacted with $R$ and interacted with $D$. \\
\hline$L F_{-} R$ & $L F$ interacted with $R$. \\
\hline$L F_{-} D$ & $L F$ interacted with $D$. \\
\hline$L F \_R \_D$ & $L F$ interacted with $R$ and interacted with $D$. \\
\hline$L C S \_R$ & $L C S$ interacted with $R$. \\
\hline$L C S \_D$ & $L C S$ interacted with $D$. \\
\hline$L C S \_R \_D$ & $L C S$ interacted with $R$ and interacted with $D$. \\
\hline$L F S \_R$ & $L F S$ interacted with $R$. \\
\hline$L F S \_D$ & $L F S$ interacted with $D$. \\
\hline$L F S \_R \_D$ & $L F S$ interacted with $R$ and interacted with $D$. \\
\hline
\end{tabular}




\begin{tabular}{|l|l|}
\hline \multicolumn{2}{|c|}{ Panel D: Independent Variables- Governance } \\
\hline$A F$ & Total amount of audit fees deflated by total assets. \\
\hline$B S$ & Total number of directors on the board. \\
\hline$B M$ & Total number of board meetings. \\
\hline$O D$ & The number of out side directors on the board divided by the total number of directors on the board. \\
\hline OutsideDir & The total numberof outside directors. \\
\hline$L C_{-} A F$ & $L C$ interacted with $A F$. \\
\hline$L C_{-} B S$ & $L C$ interacted with $B S$. \\
\hline$L C_{-} B M$ & $L C$ interacted with $B M$. \\
\hline$L C_{-} O D$ & $L C$ interacted with $O D$. \\
\hline$L F_{-} A F$ & $L F$ interacted with $A F$. \\
\hline$L F \_B S$ & $L F$ interacted with $B S$. \\
\hline$L F_{-} B M$ & $L F$ interacted with $B M$. \\
\hline$L F_{-} O D$ & $L F$ interacted with $O D$. \\
\hline
\end{tabular}


APPENDIX TWO: MEAN CSCORE BY FINANCIAL YEAR

(1999-2012)

\section{8}

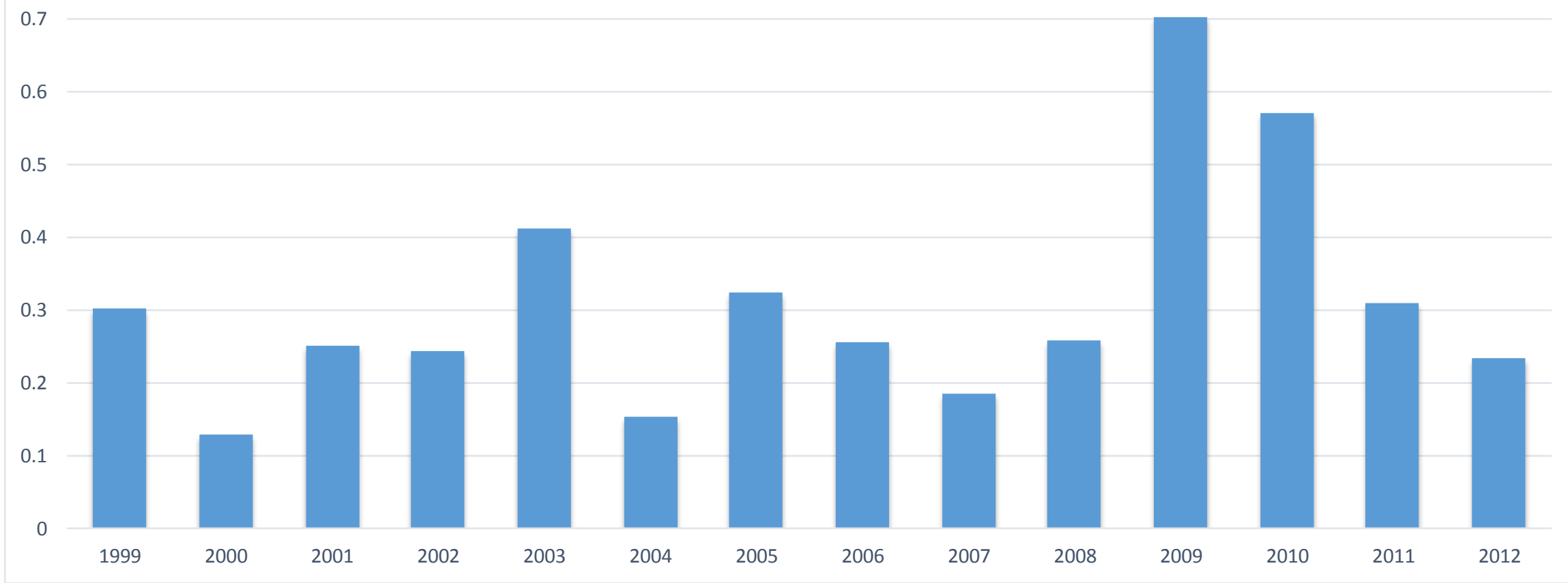




\section{APPENDIX THREE: A SELECTION OF CASE SUMMARIES}

A selection of cases from the securities lawsuit sample are summarized below.

Walt Disney Company

\begin{tabular}{|c|c|c|}
\hline Sector: Services & Securities Market: NYSE & Ticker Symbol: DIS \\
\hline Lead Plaintiff & Lawsuit Timeframe and Outcome & Alleged Conduct \\
\hline $\begin{array}{l}\text { Glancy Binkow \& GoldBerg LLP, Johnson \& } \\
\text { Perkinson, Kirby McInerney \& Squire LLP, } \\
\text { and Wolf Haldenstein Adler Freeman \& Herz } \\
\text { LLP. }\end{array}$ & $\begin{array}{l}\text { The initial lawsuit was filed August 2002. The lead plaintiff } \\
\text { was certified September } 2003 \text {. } \\
\text { In November 2003, the case was dismissed with each side } \\
\text { paying its own costs. }\end{array}$ & $\begin{array}{l}\text { The complaint alleged that Disney failed to disclose a lawsuit } \\
\text { involving hundreds of millions of dollars in possible royalty } \\
\text { payments and the potential for a loss of } \$ 2-\$ 6 \text { billion in } \\
\text { licensing revenue, relating to the character Winnie the Pooh. } \\
\text { In May, 2002, the defendants revealed the number of legal } \\
\text { claims and the possible outcomes of the legal action. Disney's } \\
\text { stock price fell, decreasing } 28 \% \text { over the next two months. }\end{array}$ \\
\hline
\end{tabular}




\section{QuadraMed}

\begin{tabular}{|l|l|l|}
\hline \multicolumn{1}{|c|}{ Sector: Technology } & \multicolumn{1}{|c|}{ Securities Market: NASDAQ } & \multicolumn{1}{c|}{ Ticker Symbol: QMDC } \\
\hline \multicolumn{1}{|c|}{ Lead Plaintiff } & \multicolumn{1}{|c|}{ Lawsuit Timeframe and Outcomed Conduct } \\
\hline Richard Patterson. & $\begin{array}{l}\text { The initial lawsuit was filed October 2002. The lead plaintiff } \\
\text { was certified on October 2003. }\end{array}$ & $\begin{array}{l}\text { The complaint alleged that the defendant made a series of } \\
\text { false and mis leading statements concerning QuadraMed's } \\
\text { business and financial condition between May 2000 and } \\
\text { August 2002. } \\
\text { In May 2004, a stipulation of settlement between the parties } \\
\text { was approved by the judge in the amount of } \$ 5.250 \text { million. } \\
\text { QuadraMed noted that it expected the settlement to be } \\
\text { principally covered by insurance. }\end{array}$ \\
\hline
\end{tabular}

\section{Polaroid}

\begin{tabular}{|c|l|l|}
\hline \multicolumn{1}{|c|}{ Sector: Consumer Cyclical } & \multicolumn{1}{|c|}{ Securities Market: NASDAQ } & \multicolumn{1}{c|}{ Ticker Symbol: PRD } \\
\hline Lead Plaintiff & \multicolumn{1}{|c|}{ Lawsuit Timeframed and Outcome } & \multicolumn{1}{c|}{ Alluct } \\
\hline Sczesny Trusts. & $\begin{array}{l}\text { The initial lawsuit was filed in August 2003. The lead plaintiff } \\
\text { was certified in September 2004. In November 2004, the lead } \\
\text { plaintiff filed a consolidated lawsuit. }\end{array}$ & $\begin{array}{l}\text { The complaint alleged that from April 2001 to August 2001 } \\
\text { Polaroid's financial statements were false and misleading. In } \\
\text { particular, the complaint alleged that Polaroid's financial } \\
\text { statements included deferred tax credits that had little or no } \\
\text { value, improper reversals of reserves and the failure to } \\
\text { classify debt correctly. The complaint also alleged that the } \\
\text { unqualified audit opinion by KPMG was false and } \\
\text { misleading. }\end{array}$ \\
\hline
\end{tabular}




\section{LeapFrog}

\begin{tabular}{|c|c|c|}
\hline Sector: Consumer Cyclical & Securities Market: NYSE & Ticker Symbol: LF \\
\hline Lead Plaintiff & Lawsuit Timeframe and Outcome & Alleged Conduct \\
\hline Alice Cupples. & $\begin{array}{l}\text { The initial lawsuit was filed in December 2003. The lead } \\
\text { plaintiff was certified in August 2005. In June 2005, the lead } \\
\text { plaintiff filed a consolidated lawsuit. } \\
\text { In September } 2008 \text {, a stipulation of settlement between the } \\
\text { parties was approved by the judge in the amount of } \$ 2.3 \\
\text { million. }\end{array}$ & $\begin{array}{l}\text { The complaint alleged that the defendants'statements about } \\
\text { its sales projections between August } 2003 \text { to October } 2003 \\
\text { were false and misleading as they failed to disclose that } \\
\text { LeapFrog had lower than forecast sales, that LeapFrog was } \\
\text { aware that Mattel's PowerTouch was outperforming } \\
\text { LeapFrog's LeapPad line, and that LeapFrog's third quarter } \\
2003 \text { projections would not be met. } \\
\text { This conduct allegedly caused significant losses to investors } \\
\text { with the share price dropping } 25 \% \text { on release of the news. }\end{array}$ \\
\hline
\end{tabular}


United Rentals

\begin{tabular}{|c|c|c|}
\hline Sector: Services & Securities Market: NYSE & Ticker Symbol: URI \\
\hline Lead Plaintiff & Lawsuit Timeframe and Outcome & Alleged Conduct \\
\hline $\begin{array}{l}\text { The City of Pontiac Policeman's and Fireman's } \\
\text { Retirement System. }\end{array}$ & $\begin{array}{l}\text { The initial lawsuit was filed in September 2004. The lead plaintiff } \\
\text { was certified in November } 2005 \text {. } \\
\text { In May } 2009 \text { a stipulation of settlement between the parties was } \\
\text { approved by the judge. }\end{array}$ & $\begin{array}{l}\text { The complaint alleged that United Rentals disseminated false and } \\
\text { misleading financial statements to the investing public. Specifically, } \\
\text { that United Rentals manipulated its financial results through the use } \\
\text { of restructuring charges, asset write-downs, debt refinancing and } \\
\text { improperly delayed recognition of bad accounts receivables. It is } \\
\text { alleged that these accounting manipulations materially inflated the } \\
\text { company's financial results. } \\
\text { This conduct allegedly caused significant losses to investors with } \\
\text { the price per share of URI dropping by } \$ 4.39 \text { per share following } \\
\text { the disclosure of the accounting irregularities. }\end{array}$ \\
\hline
\end{tabular}

\section{Ame rican International Group}

\begin{tabular}{|c|c|c|}
\hline Sector: Financial & Securities Market: NYSE & Ticker Symbol: AIG \\
\hline Lead Plaintiff & Lawsuit Timeframe and Outcome & Alleged Conduct \\
\hline $\begin{array}{l}\text { The Ohio Public Employees Retirement System, } \\
\text { the State Teachers Retirement System of Ohio, } \\
\text { and the Ohio Police and Fire Pension Fund. }\end{array}$ & $\begin{array}{l}\text { The initial lawsuit was filed in October 2004. The lead plaintiff was } \\
\text { certified in February 2005. In April } 2005 \text { the lead plaintiffs filed a } \\
\text { consolidated lawsuit. } \\
\text { In July } 2010 \text { a stipulation of settlement between the parties was } \\
\text { approved by the judge. This settlement included a payment from } \\
\text { AIG of } \$ 725 \text { million to shareholders. }\end{array}$ & $\begin{array}{l}\text { The complaint alleged that between October } 1999 \text { and October } \\
2004 \text { the defendants disseminated false and misleading financial } \\
\text { statements to the investing public. In particular, the complaint } \\
\text { alleged that the firm failed to disclose contingent commissions and } \\
\text { over reported revenues. } \\
\text { This conduct allegedly caused significant losses to investors with } \\
\text { the price of AIG shares falling } \$ 6.80 \text { per share down to } \$ 60.19 \text { per } \\
\text { share, following the disclosure of the commissions. }\end{array}$ \\
\hline
\end{tabular}


NVIDIA

\begin{tabular}{|c|c|c|}
\hline Sector: Technology & Securities Market: NASDAQ & Ticker Symbol: NVDA \\
\hline Lead Plaintiff & Lawsuit Timeframe and Outcome & Alleged Conduct \\
\hline $\begin{array}{l}\text { The New Jersey Carpenters Pension and Annuity } \\
\text { Funds. }\end{array}$ & $\begin{array}{l}\text { The initial lawsuit was filed in September 2008. The lead plaintiff } \\
\text { was certified in December 2009. In January 2010, the lead plaintiffs } \\
\text { filed a consolidated lawsuit. } \\
\text { In October 2011, the case was dismissed due to the plaintiffs' failure } \\
\text { to plead the element of scienter. }\end{array}$ & $\begin{array}{l}\text { The complaint alleged that NVIDIA issued a series of } \\
\text { misrepresentations and omissions that actively concealed and failed } \\
\text { to disclose the high failure rates of NVIDIA's mobile video adapters } \\
\text { and the impact of these defects on the company's financial } \\
\text { performance between August } 2007 \text { and February } 2008 \text {. } \\
\text { This conduct allegedly caused significant losses to investors with } \\
\text { the disclosure of the high failure rate reducing the market } \\
\text { capitalization by over } \$ 3 \text { billion. }\end{array}$ \\
\hline
\end{tabular}

Medtronic

\begin{tabular}{|c|c|c|}
\hline Sector: Healthcare & Securities Market: NYSE & Ticker Symbol: MDT \\
\hline Lead Plaintiff & Lawsuit Timeframe and Outcome & Alleged Conduct \\
\hline $\begin{array}{l}\text { The Teachers Retirement System of Oklahoma, } \\
\text { the Oklahoma Firefighters Pension Fund, } \\
\text { Frankfurt-based Union Asset Management } \\
\text { Holding AG, and Danish investment firm Danske } \\
\text { Invest Management A/S. }\end{array}$ & $\begin{array}{l}\text { The initial lawsuit was filed in December } 2008 \text {. The lead plaintiff } \\
\text { was certified in May 2009. In August } 2009 \text { the lead plaintiff filed a } \\
\text { consolidated lawsuit. } \\
\text { In October 2009, the defendant responded by filing a motion to } \\
\text { dismiss the consolidated lawsuit. In February } 2010 \text { the judge ordered } \\
\text { that the defendants' motion to dismiss was granted in part. In July } \\
2012 \text { a stipulation of settlement between the parties was approved } \\
\text { by the judge. }\end{array}$ & $\begin{array}{l}\text { The complaint alleged Medtronic, between November } 2007 \text { to } \\
\text { November 2008, issued false and misleading press releases, } \\
\text { financial statements, filings with the Securities and Exchange } \\
\text { Commission, and statements during investor conference calls, in } \\
\text { relation to one of its flagship products, the INFUSE Bone Graft. } \\
\text { This conduct allegedly caused significant losses to investors with } \\
\text { the company's stock price closing the day after the end of the } \\
\text { conduct period at } \$ 31.20 \text { per share, down from a high of } \$ 55.65 \text { per } \\
\text { share in the period before the alleged conduct. }\end{array}$ \\
\hline
\end{tabular}


Siemens AG

\begin{tabular}{|c|l|l|}
\hline Sector: Conglomerates & \multicolumn{1}{|c|}{ Securities Market: NYSE } & \multicolumn{1}{c|}{ Ticker Symbol: SI } \\
\hline Lead Plaintiff & \multicolumn{1}{|c|}{ Lawsuit Timeframe and Outcome } & \multicolumn{1}{c|}{ Alleged Conduct } \\
\hline The SEIU Greater New York Pension Fund. & $\begin{array}{l}\text { The initial lawsuit was filed in December 2009. The lead } \\
\text { plaintiff was certified in February 2010. In May 2010, the lead } \\
\text { plaintiff filed a consolidated lawsuit. }\end{array}$ & $\begin{array}{l}\text { The complaint alleged Siemens made materially false and } \\
\text { misleading statements between November 2007 and March } \\
2008 \text { concerning its ability to generate revenues and achieve } \\
\text { earnings expectations. }\end{array}$ \\
& $\begin{array}{l}\text { In March, 2010 the case was dismissed by the judge for failure } \\
\text { to state a valid claim. }\end{array}$ & \\
\hline
\end{tabular}

\section{The Boeing Company}

\begin{tabular}{|c|c|c|}
\hline Sector: Capital Goods & Securities Market: NYSE & Ticker Symbol: BA \\
\hline Lead Plaintiff & Lawsuit Timeframe and Outcome & Alleged Conduct \\
\hline $\begin{array}{l}\text { The City of Livonia Employees' Retirement } \\
\text { System. }\end{array}$ & $\begin{array}{l}\text { The initial lawsuit was filed in November 2009. The lead } \\
\text { plaintiff was certified in January 2010. In March 2010, the } \\
\text { lead plaintiff filed a consolidated lawsuit. } \\
\text { In March } 2011 \text { the case was dismis sed by the judge for failure } \\
\text { to state a valid claim. The plaintiff appealed this decision to } \\
\text { the U.S. Court of Appeals for the Seventh Circuit, where the } \\
\text { District Court's dismissal was affirmed }\end{array}$ & $\begin{array}{l}\text { The complaint alleged that between May } 2009 \text { and June } 2009 \\
\text { the defendants made false and misleading statements to the } \\
\text { market concerning the results of the testing process for the } \\
787 \text { and the company's ability to meet its schedule for the } \\
\text { first flight and delivery of the } 787 \text {. } \\
\text { Following news that the first flight of the } 787 \text { would be } \\
\text { rescheduled, the stock price fell } 6.5 \% \text { and a further } 6 \% \text { the } \\
\text { next day. }\end{array}$ \\
\hline
\end{tabular}

